\title{
Governance of a private Japanese university before and after the 1998 University Council reforms
}

\author{
Clark Marshall Egnor \\ West Virginia University
}

Follow this and additional works at: https://researchrepository.wvu.edu/etd

\section{Recommended Citation}

Egnor, Clark Marshall, "Governance of a private Japanese university before and after the 1998 University Council reforms" (2001). Graduate Theses, Dissertations, and Problem Reports. 2339.

https://researchrepository.wvu.edu/etd/2339

This Dissertation is protected by copyright and/or related rights. It has been brought to you by the The Research Repository @ WVU with permission from the rights-holder(s). You are free to use this Dissertation in any way that is permitted by the copyright and related rights legislation that applies to your use. For other uses you must obtain permission from the rights-holder(s) directly, unless additional rights are indicated by a Creative Commons license in the record and/ or on the work itself. This Dissertation has been accepted for inclusion in WVU Graduate Theses, Dissertations, and Problem Reports collection by an authorized administrator of The Research Repository @ WVU.

For more information, please contact researchrepository@mail.wvu.edu. 
GOVERNANCE OF A PRIVATE JAPANESE UNIVERSITY BEFORE AND AFTER THE 1998 UNIVERSITY COUNCIL REFORMS

\author{
by \\ Clark Marshall Egnor \\ Dissertation submitted to the College of Human Resources and Education \\ at West Virginia University \\ in partial fulfillment of the requirements \\ for the degree of \\ Doctor of Education \\ in \\ Higher Education Administration
}

\author{
Approved by \\ Dr. Richard Hartnett, Committee Chairperson \\ Dr. Robert Bickel \\ Dr. Tony Williams \\ Dr. Clair Matz \\ Dr. J. Wade Gilley \\ Educational Leadership Studies
}

Morgantown, West Virginia

2001

Keywords: Japan, Higher Education

Copyright 2001 Clark Marshall Egnor 


\section{Abstract \\ GOVERNANCE OF A PRIVATE JAPANESE UNIVERSITY BEFORE AND AFTER THE 1998 UNIVERSITY COUNCIL REFORMS}

\section{by Clark Marshall Egnor}

A major crisis facing Japanese higher education is the inability of university leaders to respond to changes, such as enrollment declines and sudden economic downturns. In response, sweeping changes were proposed by the Japanese government-appointed University Council in October 1998 that may result in increased autonomy of universities and reduced control by the Ministry of Education. This case study describes the governance patterns of a single private university in Japan and explores the following question: What are the differences between the patterns of governance at Toshi University (not the real name of the university) before and after the 1998 University Council reforms?

In order to answer this question, the study provides a description and analysis of the bureaucratic, collegial, political and other governance patterns at Toshi University as reflected through past major decisions on the functions of academic programs, faculty affairs, financial affairs and external relations. The study also examines the implications of the new reforms for those patterns. The description of governance is presented through an interweaving of interviews, relevant documents, observations and the survey results.

The researcher collected the descriptive data used for the case study analysis on site. Interviews were conducted with faculty members, administrators, students and alumni. Responses from these interviews were compared to determine who were the primary decision-makers and which decisions were most significant as they related to their impact on the mission, priorities and implications for the future direction of the university. The information from the interviews was then used to complete a survey that was used to collect data from all full-time faculty members.

The conclusion that was reached from the analysis of the research findings was that no one model can be used to describe the governance patterns that existed before and after the 1998 University Council reforms. Indeed, a mixture of models based on Japanese cultural values, such as consensus, harmony and group solidarity, is needed to describe the situation at Toshi University. It was also determined that the 1998 reforms have served to either strengthen or weaken these various patterns of governance with respect to one or more functions of decision-making. 


\section{DEDICATION}

This dissertation is dedicated to Mom and Dad who started me on this journey of learning and growth 36 years ago. 


\section{ACKNOWLEDGMENTS}

My life has been a journey of learning and growth and, at each step along those roads less traveled, there have been many people who have been there to point the way. Now I arrive at another crossroad and stop to express my gratitude to all of those people who helped me to realize the completion of this dissertation process that was once just a dream.

To Dr. Richard Hartnett, my Committee Chairperson, who walked by my side the entire way, who helped me to find the map that existed within me, and who encouraged me to follow that map and make discoveries that I never thought possible.

To Dr. J. Wade Gilley, Committee Member, who inspired me to make the journey and who taught me much about visionary leadership through example when he was President at Marshall University.

To Dr. Bob Bickel, Committee Member, who cared about me and, on more than one occasion, when I was lost, he helped me find the way.

To Dr. Tony Williams, Committee Member, who was always there with encouragement, and whose calm spirit gave me the strength to persevere, even when it was dark and the path was difficult to see.

To Dr. Clair Matz, Committee Member and travelling companion, who not only taught me a great deal about international education, but also made the journey a pleasant and enjoyable experience.

To Dr. Will Edwards, one of my best friends and a mentor, who gave me so much support and encouragement that I can honestly say that I may not have been able reach the end of this road without him. 
I also want to express my deepest appreciation to the President of Toshi University who opened his heart and the heart of his university to me so that I might learn and prosper. I will always be indebted to you and your faculty and staff for the great generosity you provided to me throughout my study. Your kind and gentle leadership was an inspiration, not just for this study, but for my life as I embark on the next stage of this life journey.

Finally, I must give thanks to my family who gave me the strength I needed to complete the dissertation process through their unconditional love and support.

To Mom and Dad, who instilled in me both the faith and optimism that have always allowed me to overcome any obstacle.

To my brother, Brad, who is always there to listen.

To Nanny, whose passion for life-long learning has been an inspiration for all of my education endeavors.

To all of my deceased grandparents, including Poppy, Granddad and Maxie, whose spirits protect and guide me on this life journey.

To my wife, Miho, my better half and life partner who helped me a great deal with many aspects of this study. My life was blessed when I met you fifteen years ago. My worldly accomplishments would have no meaning without you and our children, Laina and Logan. 


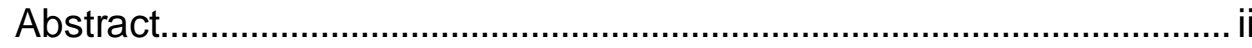

Dedication .........................................................................................

Acknowledgements.......................................................................... iv

Table of contents ............................................................................... vi

List of Figures ............................................................................... viii

List of Tables................................................................................. ix

Chapter 1 .

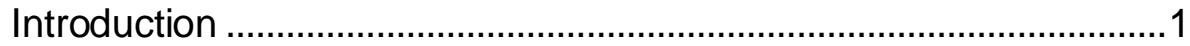

Statement of Problem ...................................................................

Rationale for Proposed Study ………………………......................

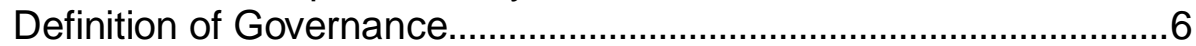

History of Japanese Higher Education and its Reforms ....................7

Establishment of a Higher Education System ..............................8

Reforming Japanese Higher Education the American Way......10

Current Higher Education Reform ................................................14

Chapter 2

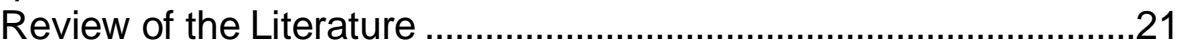

Japanese Higher Education Research ............................................21

University Governance and Organizational Structure................22

Higher Education Reform..........................................................24

Governance in Higher Education ....................................................25

Theories and Corresponding Models.........................................26

Reconciling Alternative Models of Governance ..........................32

Cultural Concepts for Analyzing Governance of Universities ...34

Autonomy as a Distinguishing Characteristic of Universities ....35

Chapter 3

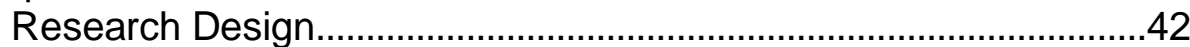

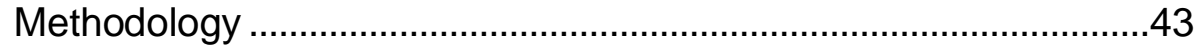

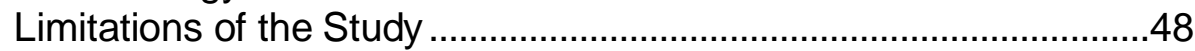

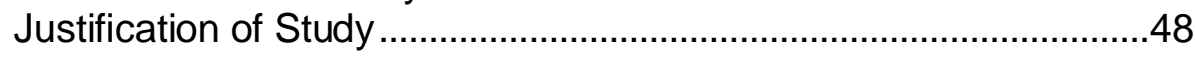

Chapter 4.

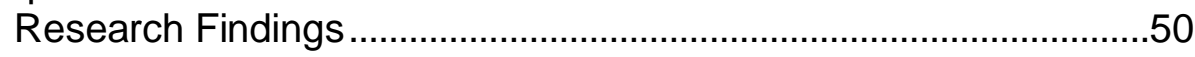

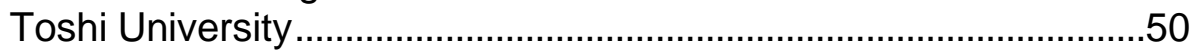

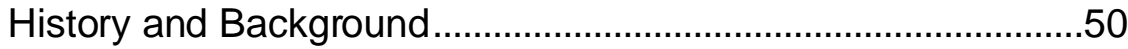

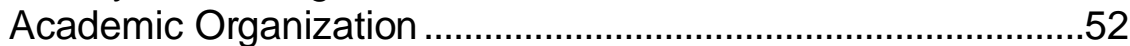

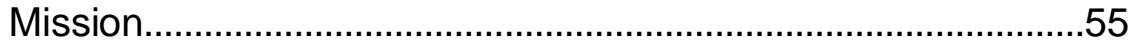

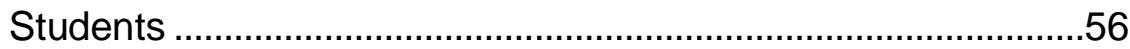

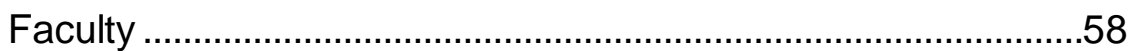

General Governance Process at Toshi University ....................91

1998 University Council Reforms ………………………………....98 
Academic Governance Process at Toshi University 105

Faculty Reactions to the 1998 University Council

Reforms and their Impact on Academic

and Faculty Affairs at Toshi University

Faculty Perceptions about the 1998 University

Council Reforms and their Implications for

Academic Governance at Toshi University

Administrative Govemance Process at Toshi University.............. 126

The 1998 University Council Reforms and their Impact

on the Financial Affairs at Toshi University

Faculty Perceptions about the 1998 University Council

Reforms and their Implications for Administrative

Governance at Toshi University....

Governance over External Affairs at Toshi University

The 1998 University Council Reforms and their Impact

on the External Affairs at Toshi University.

Faculty Perceptions about the 1998 University Council

Reforms and their Implications for Governance over

External Affairs at Toshi University

Summary

Chapter 5 .

Discussion of Findings

Discussion of the Findings in Relation to the Problem Statement144

Toshi University College of Business 154

Background on the Establishment of the New College .......... 154

Mission and Academic Organization of the New College ...... 157

The Process of Establishing the New College ......................... 158

Discussion of the Research Questions .......................................... 176

Research Question \#1 ...................................................... 176

Research Question \#2............................................................... 182

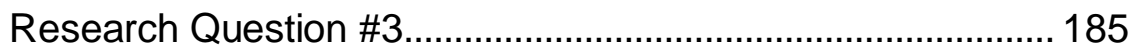

Research Question \#4............................................................ 190

Research Question \#5....................................................... 193

Japanese Characteristics of Governance ..................................... 193

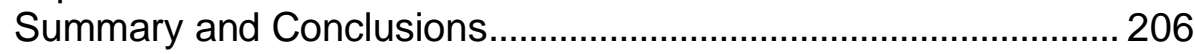

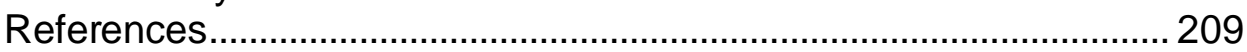

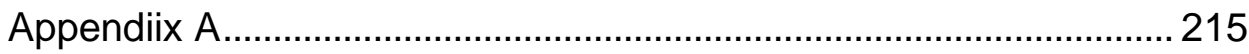

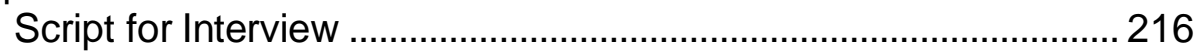

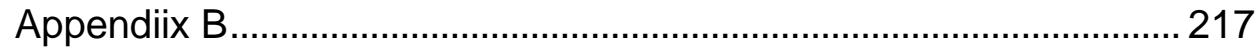

Cover Letter of Survey (English Version) .......................................218

Appendiix C...............................................................................219

Survey Instrument (English Version) ............................................. 220

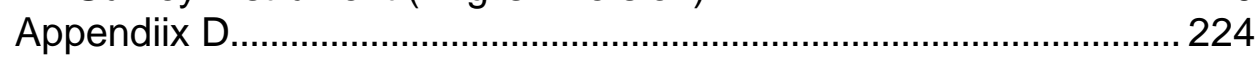

Cover Letter of Survey (Japanese Version) .....................................225

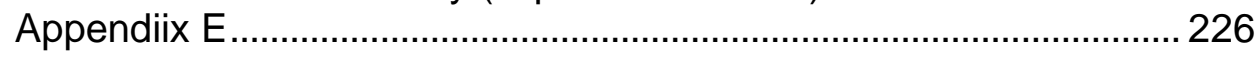

Survey Instrument (Japanese Version) ........................................ 227 


\section{LIST OF FIGURES}

Figure 1. Colleges and Departments at Toshi University .....................53

Figure 2. Administrative Divisions and Offices at Toshi University ...................................................................92

Figure 3. Decision-Making and Advisory Bodies for Academic Governance at Toshi University.......................... 106

Figure 4. Establishment of College of Business

Timeline of Events and Committees .................................... 159 


\section{LIST OF TABLES}

Table 1. Faculty Response Rates by College.

Table 2. All Faculty Respondents by Rank, Age and Years of Service

Table 3. College of Arts and Education Faculty Respondents by Rank, Age and Service.

Table 4. College of Agriculture Faculty Respondents by Rank, Age and Service

Table 5. College of Engineering Faculty Respondents by Rank, Age and Service

Table 6. All Faculty Serving in Governance Positions ..........................69

Table 7. All Faculty Involvement on Committees..................................71

Table 8. All Faculty Rank Activities According to Amount of Time Spent

Table 9. College of Arts and Education Faculty Rank Activities According to Amount of Time Spent.

Table 10. College of Agriculture Faculty Rank Activities According to Amount of Time Spent.

Table 11. College of Engineering Faculty Rank Activities According to Amount of Time Spent

Table 12. All Faculty Specify the Top Three Changes During the Past Five Years at Toshi University Affecting their Teaching, Research and Other Duties.

Table 13. Faculty Rate the Attitudes of Faculty Toward the Changes in the Curriculum that have Occurred Over the Past Five Years in their College

Table 14. Comparison of the Number of Applicants and Students Admitted at Toshi University in 1999 and 1998

Table 15. Faculty Respondents Indicate whether or not they Agree or Disagree that the Authority of the Faculty over the Curriculum has been Weakened by the Ministry of Education Reforms

Table 16. Faculty Respondents Indicate whether or not they Agree or Disagree that the Authority of the Faculty over Matters of Faculty Affairs has been Weakened by the Ministry of Education Reforms

Table 17. All Faculty Indicate Concern about Decision-making at Various Levels of Governance.

Table 18. All Faculty Indicate Opinions about Ministry of Education's Control Over the Various Functions on Decision-making at Toshi University

Table 19. Faculty Opinions about Ministry of Education's Control Over Decision-making at Toshi University 
Table 20. All Faculty Respondents' Opinions about the Changes Pending in the Reforms that could Affect their Teaching or Research

Table 21. All Faculty Respondents Indicate their Opinions about Proposals for Reforming the Existing University System Japan as Recommended Recently by the University Council

Table 22. Faculty Respondents' Agree or Disagree that the Ministry of Education should have Less Power and that More Power should be Allotted to the University's Faculty and Administration as a Way to Strengthen Decision-making

Table 23. All Faculty Respondents Indicate their Opinions about Proposals for Reforming the Existing University System Japan as Recommended Recently by the University Council

Table 24. Faculty Respondents' Agree or Disagree that Faculty Research Should be More Sensitive to Community and Business Needs.

Table 25. Faculty Respondents' Agree or Disagree that Faculty Should be Required to Participate In the Self-Evaluation of the University

Table 26. Faculty Respondents' Opinions about the Degree of Impact of the Decision to Establish the New College of Business on Faculty Affairs.

Table 27. Faculty Respondents' Opinions about the Degree of Impact of the Decision to Establish the New College of Business on Academic Affairs

Table 28. Faculty Respondents' Opinions about the Degree of Impact of the Decision to Establish the New College of Business on the Financial Affairs of the University. 168

Table 29. Faculty Respondents' Opinions about the Degree of Impact of the Decision to Establish the New College of Business on External Affairs

Table 30. Faculty Respondents' Opinions about whether or not there was wide support for the decision to establish a new College of Business

Table 31. All Faculty Respondents' Opinions about which Groups were Most Instrumental in the Development and Implementation of the New College 173

Table 32. Faculty Respondents' Opinions about whether or not Faculty were Adequately Consulted about the Establishment of the New College 
Table 33. Faculty Respondents' Opinions about whether or not Students were Adequately Consulted about the Establishment of the New College

Table 34. Faculty Respondents' Opinions about whether or not Alumni were Adequately Consulted about the Establishment of the New College 175

Table 35. Faculty Respondents' Opinions about whether or not Students' Parents were Adequately Consulted about the Establishment of the New College 


\section{Chapter 1}

\section{Introduction}

Over the past century, several key developments have shaped the Japanese university. The first development was the establishment of a higher education system in the late 1800's with the primary purpose of modernizing Japan so that it could compete with the Western powers. The second major development was the result of radical educational reforms introduced by the American occupation forces after World War II. The latest development is a series of reforms that began with the Japanese government's establishment of an ad hoc advisory council in 1984 called the National Council on Educational Reform (NCER). The NCER submitted its final report in 1987, recommending that a new University Council be established as an advisory body to the Minister of Education. The sweeping changes proposed by the University Council in

October 1998 may result in increased autonomy of universities with an emphasis on the president at the center of the power structure.

According to Philip Altbach (1991), higher education reform is change that results from a conscious process of planning and decision-making, or, as Altbach refers to simply as "planned change." In his writing on university reform in the International Higher Education Encyclopedia, Altbach (1991) also refers to a "saga of change and reform" that can give us a sense of how universities change over time. The Japanese university has been significantly shaped by the above three developments; the latest continues to shape Japanese higher education as the university community translates into action concrete plans for university 
reform. Much of the recent reform has been perceived as reactive and crisisdriven: Japanese universities face rapidly declining numbers in the traditional college-going cohort. Universities are forced to react to this dwindling eighteenyear-old population in a variety of ways (Snoddy, 1996). Another crisis involves the lack of leadership within the individual colleges and universities in Japan, which translates into the inability of university leaders to respond to changes, such as declining enrollment and sudden economic downturns. That the final report of the NCER was submitted over ten years ago and much of the recommended reform is still in the implementation stages is a testament to this lack of leadership.

In an October, 1998 report entitled, "A Vision for Universities in the $21^{\text {st }}$ Century and Reform Measures to be Distinctive Universities in a Competitive Environment," the Japanese government-appointed University Council makes its latest recommendations to the Japanese Ministry of Education, Science, Sports and Culture (hereafter referred to as Ministry of Education). One of the more controversial items in the report is the call for the "establishment of a whole university administrative structure with the president at the center." Japanese higher education researchers have long questioned the efficiency of the Japanese higher education governance system that is highly centralized at the Ministry of Education level. For example, Narita (1978) has criticized the university system as not having an efficient centralized decision-making system at the individual university level and that the "hierarchical nature of the faculty structure is not conducive to innovative proposals." Barretta (1987) has argued 
that the School Law of 1947, which provides for a strong centralized Ministry of Education that has had considerable influence on both public and private universities, should be re-drafted to give more flexibility to individual universities. The Japanese government and the public have long recognized a problem exists with the higher education system, and, in 1991, the School Law of 1947 was redrafted as recommended by the University Council, resulting in some increased autonomy for universities over their curriculum. However, most scholars still agree that more changes are needed, and the current reform movement to strengthen decision-making at the university-level could mean more comprehensive changes in the way most universities currently operate.

The following study will examine the impact the 1998 University Council reforms have had on the governance structure of a single university.

\section{Statement of Problem}

This case study examines the governance of a private university located in a metropolitan area of Japan, hereafter referred to as Toshi University (not the real name of the university), before and after the 1998 reforms and was designed to answer the following question:

What are the differences between the patterns of governance at Toshi University before and after the 1998 University Council reforms? 
To answer this question, this case study will do the following:

1. Describe and analyze the bureaucratic, collegial, political and other governance patterns at Toshi University as reflected through past major decisions on the functions of academic programs and instruction and the implications of the new reforms for those patterns.

2. Describe and analyze the bureaucratic, collegial, political and other governance patterns at Toshi University as reflected through past major decisions on the functions of financial affairs and other managerial activities and the implications of the new reforms for those patterns.

3. Describe and analyze the bureaucratic, collegial, political and other governance patterns at Toshi University as reflected through past major decisions on functions of faculty affairs (promotion, tenure, etc.) and the implications of the new reforms for those patterns.

4. Describe and analyze the bureaucratic, collegial, political and other governance patterns at Toshi University as reflected through past major decisions on functions of external relationships with key parts of the environment, including business and industry and alumni and the implications of the new reforms for those patterns.

5. Describe and analyze the bureaucratic, collegial, political and other governance patterns at Toshi University as reflected through past major decisions on other important functions not covered in \#1 through \#4 and the implications of the new reforms for those patterns. 


\section{Rationale for Proposed Study}

In 1987, a doctoral dissertation was published which examined the governance at a single private university in Japan. This case study by Mary Jane Barretta, entitled, "Rikkyo University, Tokyo, Japan: A Case Study of Governance at a Private University," sought to provide an in-depth perspective on the organizational structure of a single Japanese university. Barretta examined the relationship of the organs of governance, as detailed in the school's constitution and perceived by the administrators and faculty, to the actual management of a university in Japan. Barretta conducted interviews, analyzed documents and carried out observations of day-to-day administrative operations to produce a portrait of decision-making at a single university in Japan. Many of the reforms initiated by the NCER were just being implemented when Barretta's dissertation was published more than ten years ago. Japanese higher education has experienced many changes since then; considering the most recent reforms proposed by the University Council, the time is ripe for another case study that provides a similar in-depth perspective.

Like Barretta's study, the following case study is also about a private university. A private university, rather than a public university, was chosen for several reasons. First, private universities greatly outnumber public universities. According to the Ministry of Education, as of May 1997, there were 586 four-year universities and 595 two-year institutions. Of the 586 four-year universities, 431 were private, 57 were local public and 98 were national; and of the 595 two-year universities, 504 were private, 62 were local public and 29 were national. Over 
three million students are enrolled in these nearly 1200 higher education institutions, of which $80 \%$ were enrolled in private colleges and universities (Ministry of Education, Monbu tokei yoran, 1998b).

A second reason for selecting a private university as the focus of the case study is that private universities appear more actively engaged in reform, possibly because of their financial situation. Unlike public universities that rely totally on government financial support, private universities depend heavily on tuition revenue. Given the current enrollment declines, private universities are forced to react swiftly to the problems at hand. Therefore, a private university context for the case study may yield more opportunities to observe authority in action.

Finally, and possibly most importantly, the selection of a private university was made because it was a private university in Japan that allowed the researcher access to its university to conduct the related research.

\section{Definition of Governance}

A definition of the word "governance" is needed in order to address the problem statement. The notion of governance in higher education often refers to authority and decision-making as well as to the notion of policy-making as distinguished from administrative decisions. More specifically, as defined in the International Handbook of Education Research and Studies (Millet, 1985), governance of higher education,

... involves the authority to make decisions about fundamental policies and practices in several critical areas concerning colleges and 
universities: their number and location, their mission, their enrollment size, the access of students to their instructional programs and the access of citizens to other educational services, degree requirements, the quality standards expected of student performance, the quality of research and public service activities, the freedom available to individual faculty members in their instructional and research activities, the appointment of staff, internal organizational structure, the allocation of available resources to operating and support programs, and financial support. The first problem of governance is the location of authority to resolve these issues, internal or external. (p. 2061)

The following case study examines both the internal and external bodies of governance at a single university. The relationship between these internal decision-making bodies with each other and the interaction between the university and the Ministry of Education are central themes throughout the study.

\section{History of Japanese Higher Education and its Reforms}

To understand the current situation in Japanese higher education, background is needed that takes into account the major reforms and trends that have occurred over the past century. As mentioned previously, at least three major developments have helped to shape the current situation. The first two developments had their impetus from an external source, primarily a response to pressures from other countries. The latest reform movement differs from prior reform in that the Japanese government and the higher education community are responding to internal widespread discontent with the educational system. 


\section{Establishment of a Higher Education System}

That the modern Japanese University traces its origins to Western influences of the late 19th century, does not mean that no form of higher education existed prior to this time. Buddhist temples operated educational establishments for centuries prior to the end of the Tokugawa Shogunate (also known as the Edo Period) in 1868 and the beginning of the Meiji Restoration when Japan opened its doors to the world after 300 years of isolation. During the feudalistic Edo period, where distinctions between the ruling samurai and the common people were strictly enforced, an educational system was in place that served both groups. This system consisted of the hanko, or fief schools, for the samurai and the terakoya, which were small private schools usually run by a single teacher, for the commoners. According to Tokutake (1995), the terakoya numbered in the tens of thousands and sustained a level of literacy in Japan that equaled England and France during the $17^{\text {th }}, 18^{\text {th }}$ and $19^{\text {th }}$ centuries. The hanko, like the Western-style universities of today, concentrated on educating the samurai for positions of leadership. By the end of the Edo period, these fief schools numbered about 270 , and many were eventually augmented by the study of things Western, such as Western medicine, and played a central role in Japan's modernization following the Meiji Restoration. Both the hanko and terikoya formed a major foundation of the new school system that was later centralized under the Ministry of Education and the Japanese Imperial government. 
The establishment of a Westernized Japanese higher education system was strongly influenced by the goals of its national government. In his essay on Japanese higher education in Green's (1997) Transforming Higher Education : Views from Leaders Around the World, Tadao Ishikawa (a former president of Keio University) illustrates this in the following brief history of Japanese higher education. According to Ishikawa, the history of higher education in Japan began in 1868 when the Meiji Restoration ended nearly 300 years of feudal rule, bringing to power a group of men fixed on the idea of modernizing Japan so that it could compete with the Western powers.

The goal of the Meiji Restoration was, essentially, to modernize Japan and to build it into an independent, strong, and prosperous nation through the introduction of Western civilization. The slogan "rich country, strong military" epitomized these objectives. The leaders of this period felt that the pace of modernization would be accelerated by raising the educational level of the Japanese people. In short, they viewed education as a prerequisite to modernization. (Green, p. 295)

It's interesting to note that Japan adopted Western models of higher education, although it was neither colonized nor dominated by a single Western power. As Nakayama (1989) writes in his article that examines western impacts on Japanese higher education, ... there was no colonial-type authority to enforce adoption of a particular existing foreign model, which contrasts sharply with the post-war Japanese experience during the American occupation period of 1945 to 
1952. Western influence in the nineteenth century was exercised only on an individual basis by employed Western consultants rather than through a well-formulated national or corporate assistance program as is often the case in the contemporary Third World context. (p. 32)

According to Kitamura (1991), this new model of higher education established by the strong initiatives of the central government laid the groundwork for the establishment of the University of Tokyo in 1877, which was later reorganized in 1886 as the Imperial University. Since its founding, the Imperial University (now known as Tokyo University) has become the center for academic research and the training of scholars and civil servants. Soon after the establishment of the first national university, several private universities were also established, such as Keio University and Waseda University. These private universities received no support or encouragement from the government, but were founded by wealthy intellectuals, such as Fukuzawa Yukichi and Okuma Shigenobu respectively, who had traveled extensively in Europe and were eager to promote western ideas in Japan.

\section{Reforming Japanese Higher Education the American Way}

The pattern of higher education reform in Japan has corresponded to what Trow (1972) has described as a worldwide movement of academic systems from elite to mass with regard to access. According to Kitamura (1991), the transition from "elite" to "mass" in Japan actually began before World War II.

The University Ordinance (daigaku-rel) and other laws on higher education were promulgated in 1918, and the policy of expanding higher 
education was adopted by the central government. Following this reform and planning, various types of institutions of higher education, both public and private, were able to attain university (daigaku) status and thereby respond to the rising demand for higher education. (p. 491)

These new laws allowed private institutions to become officially chartered as universities if they could demonstrate and maintain the prescribed standards. This reform enabled a rapid expansion of higher education and set the pace for the mass system that Japan has today. However, a much greater period of reform occurred following Japan's defeat in World War II, which not only accelerated its transition toward a mass system of education, but completely restructured it based on an American model.

One of the initial purposes of the Occupation was the eradication of ultranationalistic and militaristic ideology in Japan. The Allies decided that in order to replace that ideology with "democratic" thought, it was imperative that a comprehensive educational reform should be instituted. Even though the Occupation Forces consisted of representatives of several Allied powers, the occupation of Japan, in contrast to the occupation of Germany, was administered almost exclusively by the United States. Hence, the model for post-War reform, of not only educational but various other institutions, was purely American. (Nakayama, 1989, p. 39)

Nakayama (1989) identifies at least seven areas of higher education reform proposed during the period of 1945 to 1953, although not all were accepted. Instituted reforms included: 1) the introduction of a single-track 6-3-3- 
4 school ladder based on the American model; 2) the separation of higher education into two basic institutions called daigaku (university) and tanki-daigaku (junior colleges) offering both general and specialized education (replacing the old prewar multitrack system of higher education, characterized by a hierarchy of status and considered elitist by the American reformers); 3) the expansion of higher education to the extent that each prefecture (46 in number) would have its own university; 4) the inclusion of a liberal arts education in the four-year degree; and 5) the introduction of graduate level education.

In addition to the above five changes, the Americans also tried to disband the Ministry of Education and delegate supervisory power of universities to the prefectural educational commissions that would answer to an American-style "Board of Trustees" composed of lay people. According to Nakayama (1989), this attempt to decentralize the higher education system and give academic control to lay people was never realized due to strong opposition from the Japanese government and academic community. Therefore, despite the many significant changes brought about by the American reformers, higher education's academic decision-making power continued to reside with the faculty, and the Ministry of Education continued to exert strong centralized control over both public and private universities.

According to Beauchamp and Rubinger (1989), during the postwar period, three major legal enactments fundamentally shaped the structure of Japanese education as no other educational legislation to date. The first enactment was the Japanese Constitution, which makes specific references to education. For 
example, all forms of discrimination, including gender discrimination, are outlawed and academic freedom is guaranteed. The second enactment is the School Education Law of 1947 (gakkou kyouiku hou) which called for a single track 6-3-3-4 school ladder and addressed issues such as the university's objectives, organization, terms of study, academic degrees, and academic staff and their duties. The third document of great importance is the Fundamental Law of Education of 1947 (kyouiku kihon hou) which replaced the Imperial Rescript of Education as the basic educational policy. It provides for ... nine years of free compulsory schooling, respect for academic freedom, equal educational opportunity for all, and the promotion of a broad social education by the establishment of such institutions as libraries, museums, citizens' public halls, etc. In addition, partisan political activity and the teaching of religion in publicly supported schools is prohibited. (Beauchamp \& Rubinger, 1989, p. 120)

All three of the above American occupation-influenced enactments have become firmly rooted in the Japanese higher education system. The reforms did not, however, make the Japanese University a mirror image of its American counterpart. For example, the Japanese higher education system is much more centralized at the national level with less autonomy given to the individual public and private universities over their academic and administrative decision-making. 


\section{Current Higher Education Reform}

During the late 19th century, the establishment of a higher education system was the result of external pressures from the Japanese government and its eagerness to compete with the Western Powers. After World War II, the Western Powers themselves, specifically the United States, exerted pressure on the Japanese higher education system to reform. In neither of these two developments was there significant stimulus from Japanese society at large to develop and implement these reforms. However, during the 1960's, students in Japan, like their counterparts around the world, may have played a significant role in stimulating reform and change in higher education for decades to come.

Much of the discontent attributed to the widespread student unrest in Japan during the 1960's could be attributed to the students' dissatisfaction with the quality of the education they were receiving (Shimbori, 1969). Overcrowded classrooms, incompetent lecturers, total indifference to the students, and everincreasing tuition were becoming the norm. The university had become too crowded and impersonal, and this situation laid the groundwork for numerous campus demonstrations, in some cases as violent and culturally upsetting as the demonstrations in the United States. While the students in Japan did not directly design and implement any reform, their discontent would later spread throughout Japanese society and increase demands for a more responsive university.

According to Altbach (1991), the most important impact of the student activism of the 1960's was that 
... governments began to take a direct and sometimes intense interest in higher education as universities consumed ever larger amounts of public money and as academic institutions assumed an ever more central place in the economies of both postindustrial societies and the developing nations of the third world. Expansion led to a range of other "crisis" in higher education that called for attention. Some of the proposed solutions to these problems led to parallel proposals for reform. (p. 264)

In addition to widespread discontent among students, expansion was also a distinctive characteristic of higher education in Japan during the 1970's. Kitamura (1991) provides the following statistics:

By 1960 enrollment had increased to more than one million students in 525 institutions (245 universities and 280 junior colleges); by 1970 to 1.6 million students in 851 institutions (382 universities and 479 junior colleges); and by 1980 to 2.2 million students in 963 institutions (446 universities and 517 junior colleges). The admission rate to junior colleges and universities for eighteen-year-olds was less than 10 percent in 1950 , but rapidly climbed to 23.6 percent (male 29.2 percent; female 17.7 percent) by 1970 , and to 37.4 percent (male 41.3 percent; female 33.3 percent) by 1980 . (p. 493)

Due to this expansion and growing discontent, the Japanese government finally began to respond in the 1970's, for the first time since World War II, with definite plans and legislative action for higher education reform. The first longrange plan for the general design of higher education was submitted in 1976. 
This plan, which sought to control expansion for the period of 1975 to 1980 , was based on recommendations from the Central Council on Education, an advisory organ to the Minster of Education (Kitamura, 1991). Another example of the government's increased responsiveness to the social discontent over higher education was the Private School Promotion Subsidy Law of 1975, which signaled the beginning of an increasingly critical attitude by the government toward a rapidly expanding private education sector. According to Narita (1978), this law increased the level of control of the Ministry of Education over the private universities by subsidizing private universities up to a limit of 50 percent of their maintenance expenditure. In order for a university to accept these substantial subsidies, it had to agree not to establish new colleges, departments, or increase student enrollment for a period of five years (1975 to 1980), except in special cases, such as fields of study where social needs were great. Also, private universities were required to make periodical financial reports in accordance with guidelines set by the central government.

This trend toward more government involvement in higher education problem-solving culminated in 1984 with the establishment of an ad hoc advisory committee that reported directly to Prime Minister Nakasone and made recommendations for education reform. The creation of such an important advisory committee that would report not to the Ministry of Education, but directly to the Prime Minister, illustrated the government's growing concern over the widespread discontent with higher education by Japanese society. The National Council on Educational Reform examined eight issues (NCER, 1986), including: 
1) basic requirements for an education relevant to the twenty-first century; 2) organization and systematization of lifelong learning and correction of the adverse effects of undue emphasis on the educational background of individuals; 3) enhancement of higher education and individualization of higher education institutions; 4) enrichment and diversification of elementary and secondary education; 5) improving the quality of teachers; 6) coping with internationalization; 7) coping with the information age; and 8) review of educational administration and finance. (pp. 1-2) The NCER made its final report to the Prime Minister in 1987. The NCER's recommendations included ... improvement of undergraduate education, the reform of the procedures for selecting university entrants, the improvement and expansion of institutions of higher education in accordance with A New Plan for Higher Education, and-in the light of the anticipated demographic trends in the cohort of eighteen-year -olds-the enhancement of graduate education. The council also recommended that a new University Council be established as an advisory body to the minister of education. (Kitamura, 1991, p. 494)

In 1987, the University Council was actually established and as recent as 1998 was still deliberating strategies for implementing reforms recommended by the NCER. In an October 1998 report entitled, "A Vision for Universities in the $21^{\text {st }}$ Century and Reform Measures To Be Distinctive Universities in a Competitive Environment," the University Council made its latest 
recommendations to the Ministry of Education. The proposals included reforms to improve the quality of education and research, strengthen decision making at the universities, and develop better ways to assess the institutions. An article in the Chronicle of Higher Education (Findlay-Kaneko, Nov. 6, 1998) described the Council's proposed reforms as "sweeping changes." The $\underline{\text { Chronicle }}$ article noted that while the report "stops short" of endorsing the concept of university autonomy, it did "raise the possibility of allotting more power to a university's faculty and administration as a way to strengthen decision making."

In addition to direct government involvement in higher education reform, university autonomy has also become a recurring theme during the post-war period. While these trends may appear on the surface to be a contradiction, it is actually the government-initiated reforms that have been calling for more autonomy for universities over their decision-making. The movement to give universities more autonomy can be traced back to the American occupation when the United States unsuccessfully attempted to decentralize control over education at the national level. The current recommendations for increased autonomy of universities by the University Council are in response to earlier reform plans first articulated in a 1971 report by the Ministry of Education's Central Council. The Central Council's report was entitled "Basic Measures for a Comprehensive Policy of Future School Education" which addressed university administration as its main focus. According to Osaki (1997), the report, called for a system of greater autonomy corresponding with greater responsibility, while it admonished against factionalizations within the 
university. To accomplish this, the report stressed the importance of an institutional administrative structure where executive functions are centered around the president. (p. 161)

The National Council for Education Reform recommended greater autonomy in its 1987 report and, since then, laws and ordinances governing higher education in Japan have been revised to give individual universities more autonomy over their decision-making. For example, the University Establishment Standards, an ordinance from the Ministry of Education in the School Law of 1947 which prescribes standards for academic staff qualifications, framework for curricula, graduation requirements, and minimum facility/equipment standards, was revised in 1991. According to Osaki (1997), the revisions have provided universities with more autonomy over curriculum and have also resulted in reduced evaluative monitoring of individual higher educational institutions by the Ministry of Education.

The 1998 University Council reforms come the closest yet to endorsing the concept of university autonomy. According to a cover story article in the May 2000 issue of Look Japan:

In the 12 years since the establishment of the University Council, the government has undertaken many reforms, including self-inspection and assessment, more flexible undergraduate systems, and further improvement of graduate programs and university management systems. The 1990s have been witnessed as a decade of reform, and the Council's 
1998 report was considered a grand summation for the century.

(Yamamoto, 2000, p.33)

Given the fact that much of the decision-making authority in the Japanese higher education system has until now resided with the Ministry of Education, this current reform movement could bring about radical changes in the organization of higher education in Japan. The reformers hope that stronger presidents will help the university to more effectively deal with the many problems now facing the Japanese University, such as declining enrollments, internationalization, and financial downturns. Until recently, most universities relied heavily on the Ministry of Education for their major decision-making and whatever autonomy did exist, rested with the faculty, not the president. This has begun to change. Increasingly, private universities, and even some public universities, are beginning to exercise a greater autonomy through a strong president. 


\section{Chapter 2}

\section{Review of the Literature}

This chapter provides a theoretical framework that can be used to analyze the models of governance that exist at Toshi University, some of which were proven to be more or less illuminating. Importantly, the models and theories discussed in this literature review are grounded in Western culture and may not apply in Japan. Higher education has only recently become an established area of research in Japan; thus, comparative perspectives on governance and organizational theory are lacking. A review of the literature on Japanese higher education will therefore be provided for an understanding of the research context of the case study. Of special interest here are sources that deal with academic governance, decision-making, organizational structure and higher education reform, followed by a presentation of the various models of governance found in the literature. Next, the review discusses the various environmental contingencies, namely the culture and the centralized context of higher education in Japan, that influence and shape the patterns of governance of a private Japanese university.

\section{Japanese Higher Education Research}

Interest in Japanese higher education outside of Japan increased dramatically with Japan's emergence as a world economic superpower in the early 1980's. Numerous publications on Japanese higher education are now available in English. Recent articles and books often focus on the problems now facing Japanese higher education, such as the declining enrollment of traditional- 
age students, internationalization, graduate education, research functions of the university, gender issues, employment in higher education, the entrance examination system and policy issues. This situation was not the case twenty or even ten years ago, when higher education was just becoming recognized as a field of study. Now, several academic units that focus on higher education issues, including the first and most prominent of the group, the Research Center of the Study of Higher Education at Hiroshima University. The Ministry of Education is also a major source of research on higher education in Japan. Many of its publications on higher education, such as up-dates on reform initiatives and statistical information, can be obtained from its various publications and its website.

\section{University Governance and Organizational Structure}

One of the first in a long line of works to detail the problems of the universities in Japan was Nagai's $\underline{\text { Higher Education in Japan: Its Take-off and }}$

Crash, which was published in 1971. The book begins with an examination of the historical development of Japanese higher education and discusses possible paths of reform. The author then explores current problems that are outgrowths of the more recent educational expansion and economic growth, such as the student unrest of the 60's and early 70's. Since Nagai's book was published, a steady flow of research, much of it published or translated into English, has examined the higher education system in Japan. Many of these books and articles have addressed the issues of governance, such as Osaki's (1997) article that describes the structure of university administration. Private university 
governance is addressed in an article by Cummings (1997) entitled, "Private Education in Eastern Asia," which examines the growth of private education in Asia, including Japan where the private sector provides nearly $80 \%$ of the higher education to its people.

One of the first examinations of authority and organizational structure ever conducted was a study undertaken by the Research Institute for Higher Education (RIHE) at Hiroshima University in 1973. A questionnaire was sent to faculty in national, local public and private universities throughout Japan. This national survey of faculty was the first ever attempted in Japan by an agency outside of the Ministry of Education. According to Narita (1978), the results of the study showed that the Japanese higher education system lacked an efficient, centralized decision-making system, and he argued that the "hierarchical nature" of the faculty structure was not conducive to innovation and adaptability to change.

Mary Jane Barretta (1987) used a survey modeled on the 1973 RIHE instrument as part of her case study on a single private university in Japan. The case study was conducted for a doctoral dissertation entitled, Rikkyo University, Tokyo, Japan: a case study of governance at a private university. With the assistance of the original developer of the instrument, Kitamura Kazuyuki, she updated and adapted the instrument to fit the current situation of the university under study. Barretta also conducted face-to-face interviews with administrators. Barretta's study describes the structures of governance at a single university and compares her findings from the survey and interviews with the description of the 
governing bodies and their specific responsibilities as written in the school's constitution. Barretta found that the Western-based models of governance did not adequately describe the governance system at the university in her study.

\section{Higher Education Reform}

Reforming the university in Japan has also been a major topic in the literature. Altbach's (1983) article "Comparative University Reform" in Comparative approaches to higher education: curriculum, teaching, and innovation in an age of financial difficulties, discusses the need for reform in Japanese higher education. Cummings' (1994) article, "From knowledge seeking to knowledge creation: the Japanese university's challenge," makes the argument that Japan needs to enact reform to reverse the traditional focus of education that encourages conformity and to inject more flexibility into the higher education system. Current reform movements are examined and deemed inadequate to achieve this greater openness, including proposals to expand graduate education and expand university-industry collaboration. Motohisa (1989) discusses higher education finance reform in a report by the Research Institute for Higher Education, called Financing higher education in Japan: trends and issues. The article provides an outline of the higher education finance system in Japan and demonstrates the flow of government expenditures and the importance of student support in the case of private universities. Various articles and books have addressed the internationalization of Japanese higher education as a needed reform, including Lincicome's (1993) article, "Nationalism, internationalization, and the dilemma of educational reform in Japan." 
The literature also discusses the many changes that have resulted from the reforms and external pressures from the environment. Kitamura's (1991) article "Japan: an education-oriented society," in the International higher education: an encyclopedia, provides an overall account of current trends and practices in the Japanese educational system, including the fundamental structural changes that are occurring in the 1990s among Japanese colleges and universities. Manabe's (1996) book, Gendai daigakuron josetsu : Nihon mondai no ichi-kyokumen to shiteno daigaku mondai provides an overview of the current challenges facing universities in Japan, including the expansion and diversification of universities, the changing role of faculty, research, finances and internationalization. Arimoto \& Weert's (1993) article, "Higher education policy in Japan," in Higher education policy : an international comparative perspective, provides an overview of the role that government educational policy plays in making changes in the Japanese higher education system. The authors argue that the government and academic oligarchy make up the most powerful forces in the Japanese education system, especially in the national and public sectors. Recently, however, declining enrollments have resulted in more market-driven direction and competition between the public and private sectors.

\section{Governance in Higher Education}

The purpose of this case study is to investigate the governance structure of a private university before and after the 1998 reforms. A theoretical framework is, therefore, needed in order to analyze the models of governance at the university, both before and after the reform. The distinguishing characteristics of 
academic organizations will be discussed and the four major governance models for academic organizations will be described. Also, a specific organizational theory underlies each of the four models of governance to be discussed. The relationship between organizational theory and models of academic governance is rarely discussed in the higher education literature (Bess, 1988), but may provide a useful framework for the qualitative analysis carried out in this case study.

\section{Theories and Corresponding Models}

Governance as defined in this study is what Bess (1988) refers to as "participative decision-making." Governance of higher education institutions differs from the operation of other types of organizations. Colleges and universities are unique organizations, as reflected in their style of decision making. According to Baldridge, Curtis, Ecker, and Riley (1977a), at least five major characteristics distinguish academic organizations, the chief one being that they rarely have a single mission. The goals of a college or university are ambiguous, and when attempts are made to concretely specify the goals, they quickly become contested. Another characteristic of higher education organizations is that they "serve clients instead of seeking to make a profit, their technologies are unclear and problematic and professionals dominate the work force and decision-making." The final characteristic that sets colleges and universities apart from hospitals, government agencies, business firms and so on, is their "environmental vulnerability." The autonomy of a higher education institution, which will be discussed in more detail later, plays a critical role in its governance. 
In order to understand the complex decision making process that characterizes a college or university, one must organize his or her perceptions toward a model. Three models of governance frequently mentioned in the literature are 1) the bureaucratic model, 2) the collegial model and 3) the political model. (Baldridge, et al, 1977a). A fourth model described by Cohen \& March (1974) as "organized anarchy" has also received widespread attention in the literature. These models allow higher education researchers to examine the complexities of the decision-making process that occur within an academic organization. Bess (1988) has noted that the bureaucratic, collegial and political models of governance correspond to long-standing and competing theories of organization. These organizational theories are: bureaucracy, human relations, and conflict, respectively. According to Bess, each of these perspectives is "based on and shaped by underlying assumptions about human nature, social systems, and the strength of contingencies that drive and constrain organizations."

The Bureaucratic Model of Governance. Max Weber (1947) put forth a theory of bureaucracy that underlies the bureaucratic model of academic governance. According to Weber, bureaucracies are characterized by their division of labor and specialization, an impersonal orientation, a hierarchy of authority, rules and regulations and a career orientation. An extension of Weber's theory can be found in the principles of Taylor's (1911) scientific management. According to Bess (1988), the guiding principle here is 
... that human beings can be programmed in the same way as machines through a careful analysis and planning of job design and organizational structure. Moreover, workers will be content in positions in which they see themselves as legitimately placed by virtue of experience and career. The processes of decision making in this model are decentralized to persons at the lowest possible organizational levels appropriate to the type of decision, with recourse to persons in positions at upper levels when insufficient expertise exists below. Conflict is presumed to be temporary and resolvable through the acknowledged, legitimate hierarchy. (p. 3)

Baldridge, et al (1977a) argue that the bureaucratic model does not adequately summarize university governance and the decision-making processes that occur within an academic organization. They give the following five reasons:

First, the bureaucratic model tells us much about authority-that is, legitimate, formalized power-but not much about informal types of power and influence, which may take the form of mass movements or appeals to emotion and sentiment. Second, it explains much about the organization's formal structure but little about the dynamic processes that characterize the organization in action. Third, it describes the formal structure at one particular time, but it does not explain changes over time. Fourth, it explains how policies may be carried out most efficiently, but it says little about the critical process by which policy is established in the first place. Finally, it also ignores political issues, such as the struggles of various interest groups within the university. (p. 36) 
The Collegial Model of Governance. According to Bess (1988), the collegial model of governance is grounded in the "human relations" theory. The human relations movement developed in reaction to a wide spread discontent with the bureaucratic models of administration. Human relations studies can be traced back to the Hawthorne studies conducted by Elton Mayo and Fritz Roethlishberger during the 1920's and early 1930's (Owens, 1991). These researchers undertook a series of studies at the Hawthorne plant of the Western Electric Company in Chicago and examined the relationship between the quality and quantity of illumination and its impact on the efficiency of factory workers. They discovered through repeated studies a human variable in the amount of productivity demonstrated by the workers. One of the most significant findings in the Hawthorne studies was the impact of an informal organization on the performance of the workers.

The collegial model places the individual above the organization in terms of priority of attention. Most higher education scholars agree that the major themes of the collegial model of academic governance, including "decision making by consensus, the professional authority of faculty members and the call for a more humane education" are more utopia than reality. (Baldridge, et al, 1977a) According to Bess (1988),

... a perfectly designed collegial system would permit members of the institution to participate in all matters that they felt were relevant to their personal needs, regardless of the organizational legitimacy or need for that participation. The structures of decision making under the collegial 
model appear, therefore, to be rather cumbersome, redundant, and inefficient, as participation tends to be fluid and permissive, rather than constrained by organizational needs. Decision-making processes in collegial organizations also tend to be more discursive, rather than parsimonious, as all interested parties must be given opportunities to have their say, both formally and informally. (Bess, p. 3)

The Political Model of Governance. The underlying organizational theory for the political model of academic governance can be traced back to conflict theory, which is based on "the notion of inevitable and irreconcilable differences among organizational participants" (Bess, 1988). Baldridge was the first to pose a "political" model of university governance in his book, Power and Conflict in the University (1971b). According to Bess (1988), in this model ... the division of labor, endemic to complex organizations, constrains workers to displace goals and to 'suboptimize' around subunits rather than the organization as a whole. Combined with accompanying breakdowns in communication that 'limit their rationality,' workers, proponents of this school suggest, will invariably find themselves in conflict with one another. The resolution of those conflicts, in turn, will take the form of bargaining and politics, in contrast to organizationally rational decision making under the bureaucratic model or consensus formation under the collegial. Decision-making structures in the political model can be either bureaucratic or collegial, or both, with politics as a process impinging on both. (Bess, p.4) 
Analysis provided by Baldridge offers a description of university governance that clearly emphasizes certain factors over others. Baldridge noted that the university

... was primarily concerned with problems of goal setting and conflicts over values, rather than with efficiency in achieving goals. Second, analysis of the organization's change processes and adaptation to its environment is critically important. The political dynamics of a university are constantly changing, pressuring the university in many directions, and forcing change throughout the academic system. Third, the analysis of conflict is an essential component. Fourth, there is the role of interest groups in pressuring decision makers to formulate policy. Finally, much attention is given to the legislative and decision-making phases-the processes by which pressures and power are transformed into policy. (Baldridge, 1971b, p. 36)

The analysis that Baldridge provides is clearly describing a political model of governance. However, Baldridge developed this political model based on a single case study of New York University during the early 1970's when the university was experiencing extremely high conflict, including severe student unrest and a financial disaster. Baldridge now admits that he may have underestimated the impact of "routine bureaucratic processes," and that he may have "overstressed the role of conflict and negotiation as elements in standard decision-making, since those were the processes apparent at the time." 


\section{Reconciling Alternative Models of Governance}

At least in the United States, colleges and universities share a commonality with regard to their decision-making structure. For example, evidence of a bureaucratic model can be observed when a legislature appropriates funding or dictates policy to the individual universities. The collegial model is evident when a faculty senate debates and votes on a resolution to revise the curriculum. The political model is evident at both the internal and external levels of the organization, as when a president forms coalitions to pressure faculty or administrative sub-units within the college or university. The political model is also evident when a wealthy member of the community donates significant funds to the university, but only under certain conditions, and influences a university president's decision. Baldridge, et al (1977a) contend that each of the three models--the bureaucratic, the collegial and the political--are able to address a separate set of problems and can be integrated into a whole system; those characteristics unique to academic organizations, such as ambiguous goals, unclear technology, and environmental vulnerability can be adequately summarized using the imagery of an "organized anarchy." The "organized anarchy" as a model of academic governance was first put forth by Cohen and March (1974) in their book, Leadership and Ambiguity. Under this model of governance, the college or university system has little central coordination or control over its decision-making. According to Cohen and March,

In a university anarchy each individual in the university is seen as making autonomous decisions. Teachers decide if, when, and what to teach. 
Students decide if, when, and what to learn. Legislatures and donors decide if, when, and what to support. Neither coordination ... nor control is practiced. Resources are allocated by whatever process emerges but without explicit accommodation and without explicit reference to some superordinate goal. The "decisions" of the system are a consequence produced by the system but intended by no one and decisively controlled by no one. (pp. 33-34)

Bess (1980) argues that "organized anarchy" as a model is perhaps inappropriate as it is more a "loosely connected set of propositions." According to Bess, the development of the "organized anarchy" as a model of governance was more a reaction among the organizational behaviorists who were "unable to establish with any reasonable degree of certainty cause and effect relationships among key structural or processual variables." Bess argues that colleges and universities do possess a "stable ongoing nature" with respect to problem solving and decision making, and that the large majority of decisions are "handled in accordance with well-accepted processes embedded in equally well-accepted structures." He also argues that these alternative views of the organization of colleges and universities can be reconciled if we discontinue the commonly held assumption that we must apply unique "analytic modes and hypotheses" in order to understand academic governance because our conceptualization of colleges and universities are also unique. According to Bess, organizational theory already provides the analytic tools to explain both structure and processes of decision-making in higher education, and an understanding of the forces to which 
the structure and processes are responsive is important. Bess describes four such forces:

... needs for efficient flows of information up and down the hierarchy, needs for coordination across parallel units in the organization, the strength of collegial norms, and needs of members of powerful groups to forward their special interests, often to the detriment of others. These forces are, in turn, products of the contingencies of environment, technology, and size. (Bess, 1980, p. 7)

\section{Cultural Concepts for Analyzing Governance of Universities}

The theoretical models used in this study were developed in the West; however, some of the patterns of governance observed may be uniquely "Japanese." The patterns of governance observed in this study were contingent on the environment, and culture is the greatest environmental contingency of all. Many aspects of Japanese culture may influence organizational structure and decision-making within institutions of higher education.

One important aspect of governance that may be influenced by culture is leadership. Is leadership as we know it in the United States the same as in Japan? According to Smith \& Krueger (1933), leadership is a universal human phenomenon that occurs among all people regardless of culture. Trow (1987) defines leadership in higher education as the "taking of effective action to shape the character and direction of a college or university, presumably for the better." Trow (1987), who contrasts the American university president with his counterparts in Europe, concludes that although there are variations by region 
and by type of institution, in general, the American colleges and universities are populated with presidential leaders who affect change on their institution. This may not always be the case, however, in Japanese higher education systems. Colleges and universities in Japan have traditionally not been permitted a high degree of autonomy, which has made it difficult for leaders to manage change effectively within their institutions. However, if the University Council reforms are successful in giving the presidential leaders of universities in Japan more power, will they in turn exercise the leadership to make the needed changes?

\section{Autonomy as a Distinguishing Characteristic of Universities}

This study is concerned with the impact a government-initiated reform has had on patterns of governance. Therefore, another important environmental contingency of interest is the centralized nature of Japan's higher education system, namely the influence of the Ministry of Education and the reforms being initiated by its University Council. The degree of autonomy an organization has vis-a-vis its environment is a critical determinant of how it will be managed (Baldridge, et al, 1977b). In the United States, colleges and universities have been characterized as becoming increasingly vulnerable to their environment (Millett, 1978). Baldridge, et al place colleges and universities on a continuum from "independent" to "captured." While higher education institutions do not have the "independence" of business firms operating in a free economy, they are not as "captured" by their environments as the public school districts that are constantly scrutinized and pressured by the communities they serve. Since the end of the Second World War, colleges and universities in both Western Europe and the 
United States have seen their authority of governance diminish while the authority of governance exercised by governments has tended to expand (Millet, 1978). According to Millet (1978), this tendency has been rooted in two primary concerns: the concern with student access to higher education opportunity and the concern with the growing cost demands presented to governments by universities.

Colleges and universities have long enjoyed a higher degree of autonomy than their counterparts in other countries, perhaps a result of early $19^{\text {th }}$ century efforts to become independent from the dominant church and the colonial states. There is a fundamental belief in American society that its interests are best served when colleges and universities are permitted to operate with a high degree of autonomy, as illustrated in the coveted practice of academic freedom. However, increased tension between governments and universities over questions of autonomy and public authority are becoming increasingly evident in the United States. This was one of the major findings in a summary of a report published by the International Council for Educational Development (Eurich, 1981) which examined systems of higher education in 12 countries. The report found that these tensions were especially evident in Canada, the United States, and the Federal Republic of Germany. In these countries, the report notes a significant trend in the increased role of government in the funding of higher education and increased central control.

While higher education in the United States becomes increasingly less autonomous, colleges and universities in Japan are currently reacting to reform 
measures which aim to decentralize their higher education system and provide more autonomy to the individual institution. This recent reform trend is the result of a growing dissatisfaction on the part of Japanese society with their higher education system and its capacity to deal with current problems, such as enrollment declines and internationalization. According to Baldridge, et al (1977b), strong external pressure has the potential to seriously reduce the operating autonomy of the college or university faculty or administrator who stand to lose control over the fundamental policies and practices governing their institution. The strong external pressure exerted by the Ministry of Education in Japan has a critical impact on the decision-making process within the individual university, albeit the private university has more autonomy than the public university. Osaki (1997) speaks of university autonomy as one of the most important issues now facing Japanese higher education when he says that the foremost challenge facing Japanese universities as they enter the $21^{\text {st }}$ century will be for them to transform their system of autonomy from the present passive one that rejects outside participation to an active, forward-moving one that takes the lead in developing educational and research programs based on a vision of societal advancement derived in close interaction with various sectors of society. (p. 163)

Clearly, the role and function of the Ministry of Education is of great interest in this case study. In fact, describing the functions of governance at Toshi University is difficult without first providing an overview of the Ministry of 
Education and the extent of its power over these various functions, and also how the decision-makers at private universities interact with the Ministry of Education.

According to Beauchamp \& Rubinger (1989), the responsibilities of the Ministry of Education range

... from the drafting of bills, preparation of budgetary requests, setting curriculum standards and textbook authorization to the operation of a variety of national schools, museums, children's centers, citizen's halls, etc. Administratively, the Ministry consists of five bureaus: elementary and secondary education, higher education, social education, physical education, and administration. The minister of education is the chief executive officer, a cabinet-level post to which he is appointed by, and serves at the pleasure of, the Prime Minister. (p. 120)

The Ministry of Education controls both public and private universities. Even the selection of faculty of national universities is subject to final approval by the Minister of Education. According to Ninomiya (1977), while the Ministry exerts much more control over the public universities, the powers of the Ministry of Education over the private university are also considerable. The Private School Law of 1949 gives the following powers to the Ministry of Education over private higher education institutions:

(1) the approval of the establishment and discontinuance of a university, a graduate school, a faculty of a university, a department of a junior college and the approval of changing the establishing body, (2) the order for closing a university if it violates regulations and laws, and (3) the power to 
require a university to present a report on researchers and statistics.

(Ninomiya, 1977, p. 5)

According to Osaki (1997), the purpose of the Private School Law of 1949 was to "enhance the public nature of private universities, while protecting their autonomy." As for protecting their autonomy, the authority of the Minister of Education over private schools is much more limited than public schools and he must consult with the Private University Council, an association of private university educators, before exercising his authority. While private universities are heavily dependent on tuition revenue, most private universities receive subsidies under the Private School Promotion Subsidy Law of 1975 as well, which obligates the private universities to operate under the Ministry of Education guidelines. The public nature of private universities is also reflected in their school corporation that imposes at least four constraints:

1) that the university president be one of the school corporation's trustees; 2) that school corporations establish a deliberative council comprised of representatives from faculty and alumni trustees on budget and other important administrative and financial matters; 3) limiting the number of close relatives serving on the board of trustees to no more than two; and 4) that should the school corporation be dissolved, the remaining assets would be transferred to another school corporation or educational institution. (Osaki, 1997, p. 156)

The system of governance of private universities is quite different from its public counterparts. According to Arimoto (1993), in public universities, the 
faculty often determine campus policies and initiate decision-making and the dean and president (who are elected by faculty and campus-wide respectively) function as an arm of the faculty body. The president of a private university, on the other hand, has much more power over financial, personnel and administrative affairs than his public university counterpart, and in some cases, the president will have ultimate decision-making authority over the curriculum, teaching and research as well. According to Kitamura (1991), private institutions rely on a board of trustees usually made up of faculty, staff and alumni for nominations and even the selection of their presidents. In most private universities, the Faculty Council, which is coordinated by an elected dean, has jurisdiction in personnel decisions and curriculum.

Many limitations are imposed on the extent to which a president or other executive officer of a Japanese university can exercise leadership, especially the president of a public university. Even in private universities, the Faculty Council and Board of Trustees may have considerable power. Actually, the power of a president or other executive officer of a Japanese university varies from institution to institution. Even some public universities, like Tsukuba University, have had strong presidents at the center of their institutional autonomy for over 20 years (Osaki, 1997). Despite these limitations, Tadao Ishikawa, former president of Keio University, a prestigious private university in Tokyo, says that the president of a private university in Japan, even one with a strong Faculty Council, can achieve a great deal (Green, 1997). According to Ishikawa, 
a president must have a vision of societal progress and an ability to speak about the future of the institution. She or he must possess a certain charm and an ability to persuade others. These qualities and skills enable a president to develop consensus ... (Green, 1997, p. 305) 


\section{Chapter 3}

\section{Research Design}

This study examines the governance of a single private university in Japan before and after the 1998 University Council Reforms. The university is referred to as "Toshi University," a pseudonym to protect the identity of the school. The name "Toshi," Japanese for "metropolitan," was selected to reflect the location of the university. At the invitation of the President of this university, the researcher visited its campus during the summer of 1999 to observe, view documents, and conduct interviews. A survey was later administered to the full-time faculty of the university in July 2000. This study was designed to answer the following question:

What are the differences between the patterns of governance at Toshi University before and after the 1998 University Council reforms?

In order to answer this question, the case study includes the following description and analysis:

1. Describe and analyze the bureaucratic, collegial, political and other governance patterns at Toshi University as reflected through past major decisions on the functions of academic programs and instruction and the implications of the new reforms for those patterns.

2. Describe and analyze the bureaucratic, collegial, political and other governance patterns at Toshi University as reflected through past major decisions on the functions of financial affairs and other managerial activities and the implications of the new reforms for those patterns. 
3. Describe and analyze the bureaucratic, collegial, political and other governance patterns at Toshi University as reflected through past major decisions on functions of faculty affairs (promotion, tenure, etc.) and the implications of the new reforms for those patterns.

4. Describe and analyze the bureaucratic, collegial, political and other governance patterns at Toshi University as reflected through past major decisions on functions of external relationships with key parts of the environment, including business and industry and alumni and the implications of the new reforms for those patterns.

5. Describe and analyze the bureaucratic, collegial, political and other governance patterns at Toshi University as reflected through past major decisions on other important functions not covered in \#1 through \#4 and the implications of the new reforms for those patterns.

\section{Methodology}

The descriptive data used for the case study analysis were collected during the researcher's on-site visit to the campus in June 1999. The researcher first conducted interviews, both structured and unstructured, with various faculty members, administrators, the President, Board of Trustees members, students and alumni. An official from the Ministry of Education was also interviewed. The structured interviews consisted of seven questions related to governance and decision-making at Toshi University (Appendix A). The questions were used in interviews with the President, Board of Trustees members, deans, department chairs, directors of institutes, administrators and various faculty members from 
each of the university's three colleges. The researcher arranged the interviews freely using the campus phone directory and, in some cases, with introductions from the President or a faculty advisor who had been assigned to the researcher by the President. Each person to be interviewed was told in advance that participation was voluntary and that he or she did not have to respond to every item or question. Participants were also told that their responses would remain anonymous and that confidentiality would be maintained. Responses from the interviews were compared to identify the primary decision-makers at Toshi University and determine which decisions were most significant as they related to their impact on the mission, priorities and implications for the future direction of the university.

Other data used in the case study analysis included the following:

1. Documentation from the researcher's participation in a Deans' Council meeting, a faculty meeting and various other school events.

2. Notes from newspapers and academic journal articles that addressed various higher education issues in Japan, such as enrollment trends and the University Council reform.

3. 1999 Toshi University Faculty Bulletin (kyooin ichiran).

4. 1999 Toshi University Organizational Chart.

5. Toshi University Organizational Chart (unknown date; translated into English).

6. 1999 Toshi University Faculty \& Staff Phone Directory. 
7. 1999 faculty and staff statistics, including number of faculty per college and department by rank; number of faculty per college and department by age; number of administrators by years of service.

8. Constitution and by-laws of Toshi University.

9. Minutes from the Oct. 1998 Future Planning Meeting for Administrative Affairs (shoorai keikaku iinkai kanri bumon toogi hookoku).

10. Transcript of 1999 "State of the University" speech by president of Toshi University.

11. Various departmental brochures.

12. Campus maps.

13. 1999 Toshi University faculty manual for student conduct (kyooshokuin no tameno gakusei shidoo yookoo).

14. 1999 Toshi University Student Club Information.

15. 2000 Toshi University Student Bulletin (daigaku naiyoo).

16. 1999 Toshi University Student Handbook (gakusei yooran).

17. Various books, articles and speeches written by or about the founder of Toshi University, its history and the unique educational philosophy of its founder.

18. Administrative timeline and various reports related to the establishment of a new College of Business.

19. Published report of survey results describing the opinions of alumni, parents and students about the educational product of Toshi University (used during planning stages of a new College of Business). 
20. Promotional brochures for the new College of Business at Toshi University.

21. $50^{\text {th }}$ Anniversary of Toshi University Photo Book which includes historical notes.

22. Enrollment statistics for each of the colleges and department by gender and year of study.

The information from the interviews and other data collection activities was used to develop a faculty survey. The survey is primarily an original instrument, but its design was guided by the 1973 instrument used by the Research Institute for Higher Education at Hiroshima University and another instrument developed by Barretta in 1987 . The survey included both multiple choice and open-ended response questions and was pilot tested before being distributed to all of the faculty members at the university. The purpose of the survey was to (a) collect basic demographic data on the Toshi University faculty, (b) determine the extent to which the faculty of Toshi University are involved in the governance process (as perceived by the faculty) and, (c) determine the attitudes of the faculty towards the administrative/governance processes that are currently in place and what the faculty consider to be the implications of the new reforms on these processes. During the interview stage of the research, it was discovered that the establishment of a new school at Toshi University was the major university-wide initiative, and therefore the establishment of this new school became the focus of some of the survey questions. The survey also allowed the faculty to indicate and comment on other major decisions that have recently affected their domain. 
Each survey was accompanied with a cover letter that provided an introduction of the researcher, the purpose of the research study and an assurance that the responses to the survey would remain anonymous and that the confidentiality of the participants would be maintained. A copy of both the English and Japanese versions of the survey and cover letter can be found in the appendices (Appendices B through E); however, only the Japanese version of the survey was used in the study.

The researcher has attempted to paint a portrait of the governance patterns as reflected through past major decisions and the implications of the new reforms for those patterns. The portrait, drawn through an interweaving of interviews, relevant documents, observations and the survey results, constitutes a case study of major university decisions before and after the recent reforms to delineate the governance patterns and the role and function of power groups (legitimate or illegitimate) within both the academic and administrative spheres. The case study analysis focuses on the effects of past decisions on the university mission, goals, priorities, etc. and examines how the changes that resulted from these decisions were viewed by the above groups. The analysis also examines what likelihood the new reforms have for being implemented and their governance implications. The portrait makes use of the various models of governance and organizational theory described in the Literature Review and examines whether certain aspects of Japanese culture are reflected in the governance of Toshi University. 


\section{Limitations of the Study}

The greatest limitation of the study was the relatively short time the researcher was on site to conduct interviews and make observations. The fact that the target culture and language are foreign to the researcher was also a limitation. The researcher lived in Japan for five years and has advanced proficiency in spoken Japanese; however, reading and writing Japanese did present a problem. For this reason, the researcher's wife, a native Japanesespeaker, assisted him with the translation and interpretation as needed.

\section{Justification of Study}

Administrative leadership and its potential to make higher education institutions more responsive to change has become of increasing interest to the Japanese government and public at large. As greater numbers of American and Japanese colleges and universities enter into collaborative agreements, more studies are needed to provide Americans and Japanese with a better understanding of the role of higher education leadership in Japan and how these leaders manage change within their respective organizations. While governance studies have been carried out extensively in the United States, much less of this type of research has been conducted in Japan. Describing the organizational structure and roles and functions of leadership provides a much needed crosscultural perspective on the models of governance. Finally, this study is important because higher education in Japan is in trouble. There is great concern among government leaders in Japan and Japanese society as a whole that higher education is failing and needs reform. This study will contribute to a 
better understanding of the problem and determine whether the reforms being implemented are effective. 


\section{Chapter 4}

\section{Research Findings}

This chapter will discuss the research findings through an analysis of the documents, interviews, and survey results. Specifically, the chapter will examine some key functions of governance at Toshi University over the academic, administrative and external affairs of the organization and discuss how the 1998 University Council reforms pertain to each of those functions of decision-making. The chapter begins with a description of Toshi University and the 1998 University Council reforms in order to provide the necessary background for understanding the analysis. This description includes Toshi University's history, academic organization, mission, students, faculty and the governance processes. Using an ethnographic approach, various news accounts from the Japanese media are presented to provide a background on the 1998 University Council reforms. A discussion of the research findings in relation to the problem statement will be reserved until Chapter 5.

\section{Toshi University}

\section{History and Background}

Under the American Occupation, the entire system of education in Japan underwent fundamental reorganization and expansion. The American authorities viewed the pre-war Japanese higher educational system as hierarchical and elitist, and they implemented major reform. Among other things, they democratized access by instituting coeducation and by scrapping the multi-track system of higher education, implementing a single-track, 6-3-3-4 school ladder 
based on the American model. The Occupation authorities also granted university status to a number of lesser institutions, and, since the war, both the number of higher education institutions and their total enrollments have increased dramatically. As a result, Japan now has 586 universities and 595 junior colleges, 62 colleges of technology and various other post-secondary institutions (Ministry of Education, Monbu tokei yoran, 1998b), compared to the 49 universities and 391 various other types of higher educational institutions that existed before the war (Kitamura, 1991). Over $90 \%$ of the universities in Japan were established after 1950, and the majority of this new growth was achieved overwhelmingly through the creation of private institutions. Toshi University, a private four-year university located in a major metropolitan area of Japan, was part of this post-war movement to expand higher education.

Established in 1952, Toshi University is part of Toshi Gakuen, or Toshi Academy, as it will be referred to in this study. A gakuen is a federation of schools, a comprehensive academy. The academy model is fairly common in Japan where university students can be seen walking on the same campus as students from kindergarten-age and older. In addition to Toshi University, Toshi Academy, founded in 1929, also includes Toshi Kindergarten, Toshi Primary School, Toshi Middle School, Toshi High School and Toshi Junior College for Women. According to the various documents that describe the history of Toshi Academy, the founder purchased 300 acres of remote and undeveloped land in one of the largest metropolitan regions of Japan and created a school based on his unique educational philosophy. The founder continued to govern the school 
as Chairman of the Board of Trustees and President until 1973 and then transferred control of the school to his son, who served as President and Chairman of the Board of Trustees until 1994. The current president is the grandson of the founder, who has served as both President and Chairman of the Board of since 1994.

\section{Academic Organization}

At the founder's death in 1977, Toshi Academy enrolled 9110 students, 5400 of which were enrolled in the University. While the number of students has increased, the number and kinds of colleges and departments have remained unchanged. As of the 1999/2000 academic year, Toshi University enrolled 6,648 students in 10 departments organized into three undergraduate colleges: the College of Arts and Education, the College of Agriculture and the College of Engineering. Two-hundred fifty-six full-time and 384 part-time faculty teach in these three colleges, some of whom also work in one or more of the following institutes: Toshi University Libraries, Toshi University Museum, Toshi University Continuous Learning Center, Toshi University Audio Visual Center, and the Toshi Research Institute which includes four research centers. Some of these faculty members are also associated with one or more of the three institutes that are shared between the University and the various lesser schools that make up Toshi Academy.

A complete list of the colleges and departments at Toshi University is provided in Figure 1. Note the way in which the Japanese distinguish between a college and department. In Japan, all institutions of high learning are referred to 


\section{Figure 1}

\section{Colleges and Departments at Toshi University}

\section{College of Arts \& Education (bungaku-bu)}

Drama \& Fine Arts (geijutsu-gakka)

Education (kyooiku-gakka)

English and American Literature (eibeibungaku-ka)

Foreign Languages (gaikokugo-gakka)

\section{College of Agriculture (noogaku-bu)}

Agronomy (noogaku-ka)

Agricultural Chemistry (noogeikagaku-ka)

\section{College of Engineering (koogaku-bu)}

Mechanical Engineering (kikaikoogaku-ka)

Electrical Engineering (denshikoogaku-ka)

Information-Communication Engineering (joohootsuushinkoogaku-ka)

Management Engineering (keieikoogaku-ka)

\section{Graduate School (daigaku-in)}

Graduate School for Arts \& Education (bungakukenkyuu-ka)

Graduate School for Agriculture (noogakukenkyuu-ka)

Graduate School for Engineering (koogakukenkyuu-ka)

Correspondence Education School (tsuushinkyooiku-bu)

Education (bungaku-bu kyooiku-gakka) 
as universities, or daigaku. Two Chinese characters represent this word. The first character is "dai," which is used as a modifier to indicate an extreme or unsurpassed level or extent, and "gaku" which means school; therefore, the word for university in Japanese can be directly translated as the "highest school." The word is even used for junior colleges, which are called tanki daigaku, meaning "short-term universities." The larger academic units that make up a university are called gaku-bu. The "bu" is used to indicate a separate division with its own faculty teaching in one or more departments, known in Japanese as gaku-ka (or gakka). Within the academic departments there are majors, or fields of study, which the Japanese refer to as koosu. The Japanese borrowed this term from English, which we know as the word, "course."

Among the three colleges at Toshi University, the College of Arts and Education is the largest, enrolling 4,102 students. One thousand six hundred and four students are enrolled in the College of Engineering, and 942 students are enrolled in the College of Agriculture. Toshi University also includes a Graduate School that currently enrolls 125 students in three divisions: Education, Engineering, and Agriculture. Actually, the graduate programs are simply an extension of the undergraduate schools and the undergraduate and graduate faculty members are almost one and the same. In addition to awarding bachelor's and master's degrees, Toshi University offers teacher certificate programs via distance learning and currently enrolls 10,446 students in its correspondence courses. According to interviews with the Dean of the College of Arts and Education, the Correspondence Education School is strongly 
affiliated with the College of Arts and Education and draws from the faculty in this college. The researcher initially made the mistake of including the Junior College for Women as one of the branches of the University; however, this college is considered a separate institution with its own organizational structure, administration and faculty. The Toshi Junior College is similar to other junior colleges in Japan, which are attended primarily by women and tend to stress the liberal arts and education. Also, as with other junior colleges, recruiting sufficient numbers of students has become increasingly difficult, and many of its degree programs are being articulated with four-year university degree programs.

Toshi University will establish a new College of Business with a separate faculty by the year 2001 . The faculty, administration and staff at Toshi University are concerned about the impact of the declining number of the traditional collegegoing cohort and decreases in future funding. They hope that the appeal of a business degree will draw more students to Toshi University.

\section{$\underline{\text { Mission }}$}

The Toshi University Student Bulletin provides the mission of the University, translated into English as follows:

- This University will offer theoretical approaches and application of knowledge and skills based on the Fundamental Law on Education (kyouiku kihon hou), the School Law of Education (gakkou kyouiku hou) and Christian Doctrine with "Universal Education" as our goal.

- Strong emphasis on religion and art will be provided in order to contribute to the happiness of human beings and the development of 
the culture. The education at this University seeks to purify the soul, develop highly sophisticated emotions and establish strict moral ethics.

- In order to achieve these goals, this University strives to enhance the standards of teaching and research through self-inspection and selfevaluation of this University's teaching and research activities.

The mission of Toshi University reflects both the Christian ideals of its founder and the integrated and universal approach to education that is consistent with its overall mission as an academy of schools that serves all ages of students. According to one of Toshi University's alum that attended Toshi Academy from kindergarten through secondary school, the education that students receive at Toshi University is unique in Japan, a country where most schools are oriented toward rote-learning and test-taking:

At Toshi University, we do not have to worry about the examination hell if we begin our education from the kindergarten or elementary school level. The education I received at Toshi University was well-rounded. Unlike other schools in Japan that just focus on taking tests, the aim of Toshi Academy is to build a human being with a rich and whole character. (Personal Communication, June 1999)

\section{$\underline{\text { Students }}$}

More so than in the United States, the university student in Japan is judged according to the school he or she attends and its place in the nation-wide university pecking order. Tokyo University, for example, ranks at the top, followed closely by a few of the prestigious private universities, namely Keio and 
Waseda. The national universities are known for producing the great majority of high-level government bureaucrats and the prestigious private universities are noted for their business executives, politicians and journalists. The larger mass of private universities represents the middle group and these schools are divided into several prestige levels, and at the bottom of the higher education ladder are the junior colleges. Those who pass the entrance exam and gain admission to a prestigious university are almost guaranteed a position in big business or government, while those who attend less prestigious schools become the lesser businessmen and white-collar workers. It should be noted, however, that the correlation between university affiliation and jobs is declining in Japan.

Toshi University, falls within the middle group of private universities. It is moderately competitive and currently admits around $30 \%$ of the students who apply and take its entrance examination. During the 1999 admission period, 8,751 students sat for the Toshi University entrance examinations for the various schools and only 2,605 passed the examinations and were granted full admission to the University. Of that total number of students who passed the exam, 1,636 students enrolled. In addition to being moderately competitive, the cost of tuition and fees at Toshi University is above average compared to other private universities in Japan, suggesting that most of the students at Toshi University come from households earning an above average income in Japan. For example, a first-year student currently pays from $1,550,000$ yen $(\$ 12,917)$ to $1,810,000$ yen $(\$ 15,083)$ for tuition for one academic year and entrance fees 
range from 925,000 yen $(\$ 7,708)$ to $1,055,000$ yen $(\$ 8,792)$. These fees at Toshi University are above the average cost of tuition for a private university in Japan.

According its Student Bulletin, Toshi University enrolls students from all 48 prefectures of Japan, but the biggest proportion of students comes from the prefecture where it is located and the surrounding prefectures. Overall, Toshi University has a roughly even number of male and female students who are admitted each year, although the gender ratio is much less balanced from college to college. Of the 9,114 applications Toshi University received for the 1999 academic year, 4,119 , or $45.1 \%$ were females. Of those prospective students who sat for the entrance exam, $44.6 \%$, or 3,910 , were female, and $47.7 \%$, or 1,244 of those applicants who were admitted were female. The College of Arts and Education admits the highest proportion of female students, about $75 \%$, followed by the College of Agriculture with a $43 \%$ female admission rate and the College of Engineering with only a 7\% female admission rate. Like most universities in Japan, the majority of students are recruited directly from high schools and there are very few non-traditional aged students.

\section{Faculty}

As with other universities in Japan, the faculty members of Toshi University can be divided into four classifications: Full Professor (kyooju), Associate Professor (jokyooju), Lecturer (kooshi) and Assistant (joshu). According to Toshi University Office of Personnel statistics, as of January 2000, Toshi University employed 130 Full Professors, 81 Associate Professors, 42 Lecturers and 3 Assistants for a total of 256 full-time teaching faculty. Other staff 
working in the academic area of Toshi University include 384 part-time instructors (hiyookin kyooin), 29 academic support staff (kyooikubumon shokuin), and 57 administrative support staff (shienbumon shokuin). Of the 256 full-time faculty members at Toshi University, 50.8\% are Full Professors, 31.6\% are Associate Professors, $16.4 \%$ are Lecturers and $1.8 \%$ are Assistants. Toshi University appears to have a higher percentage of Full Professors and Associate Professors than the average university in Japan. According to government statistics (Ministry of Education, 1998a, Gakko Kihon Chosa Houkokusho), of 144,310 faculty employed by all universities in Japan, 38.3\% were Full Professors; 23\% Associate Professors; 12.7\% Lecturers; and 25.4\% Assistants. The higher than average number of Full and Associate Professors at Toshi University may be because the faculty members at Toshi University are slightly older than average in Japan, where age and faculty rank are closely related.

As indicated in the research methodology, a survey was distributed to all full-time faculty members of Toshi University. The 1999 Toshi University Faculty Bulletin (kyooin ichiran) was used to compile the survey mailing list. The survey was sent to 256 faculty members using the Toshi University campus mail system and was accompanied with a letter of introduction from the researcher. Faculty members were instructed to return the completed surveys to Toshi University's Center for International Education within a three-week time period. The survey was distributed three times over a three-month period with an initial return of only $14 \%$. Ninety-six responses were finally received for a response rate of $37.5 \%$. As shown in Table 1, faculty responses were obtained from all three colleges 
with the highest rate of response (of actual number) obtained from the College of Agriculture (57.1\%), followed by the College of Engineering (39.7\%) and College of Arts and Education (30.5\%). It is important to note that with the first return of the surveys, the College of Arts and Education had provided the highest number of responses (as percent of the actual number). With subsequent distributions of the survey, the researcher personally made contacts with faculty members and administrators at Toshi University to encourage more returns, specifically targeting the Colleges of Agriculture and Engineering where the initial returns had been extremely low. This might explain the higher return rates of these two colleges compared with the College of Arts and Education.

\section{Table 1}

\section{Faculty Response Rates by College}

\begin{tabular}{lcccc}
\hline \multicolumn{1}{c}{ Faculty } & $\begin{array}{c}\text { Number of } \\
\text { Responses }\end{array}$ & $\begin{array}{c}\text { Actual } \\
\text { Number }\end{array}$ & $\begin{array}{c}\text { Percent of } \\
\text { Actual }\end{array}$ & $\begin{array}{c}\text { Percent of } \\
\text { Respondents }\end{array}$ \\
\hline Arts \& Education & 43 & 141 & $30.5 \%$ & $44.8 \%$ \\
Agriculture & 24 & 42 & $57.1 \%$ & $25.0 \%$ \\
Engineering & 29 & 73 & $39.7 \%$ & $30.2 \%$ \\
Total All Colleges & 96 & 256 & $37.5 \%$ & $100 \%$ \\
\hline
\end{tabular}

The purpose of the survey was to (a) collect basic demographic data on the Toshi University faculty, (b) determine the extent to which the faculty of Toshi University are involved in the governance process (as perceived by the faculty) and, (3) determine the attitudes of the faculty towards the governance processes 
that are currently in place and what the faculty consider to be the implications of the new reforms on these processes.

Faculty Rank, Age \& Years of Service. Most of those responding to the survey were younger faculty of lower academic rank and shorter lengths of service. As indicated in Table 2, about $70 \%$ of the professors who responded to the survey were at the Associate Professor rank or lower and fewer than $45 \%$ of the survey respondents were 50 years or older. The results are not reflective of the actual faculty demographic found at Toshi University. According to Toshi University Office of Personnel, about $55 \%$ of the Toshi University faculty are 50 years or older. The oldest faculty members at Toshi University are teaching in the College of Engineering where $61 \%$ are 50 years or older. About $56 \%$ of the faculty in the College of Liberal Arts are 50 or older and about $40 \%$ of the faculty in the College of Agriculture are 50 years or older. The average age of the fulltime faculty at Toshi University is 50.3 years old. According to the results of a national survey reported by Arimoto (1993), the average age of full-time teaching staff in public universities was 44.2 and 46.2 at private universities. However, it must be noted that these results are now almost ten years old and there may have been an increase in the average age of university faculty in Japan since that time (consistent with the overall aging of the population in Japan), which is closer to the average age currently found at Toshi University.

Seniority is very important in Japanese colleges and universities. For example, when faculty are collaborating on research projects, senior professors usually have the right to select topics and themes of research and in some 
Table 2

All Faculty Respondents by Rank, Age and Years of Service

\begin{tabular}{|c|c|c|c|c|}
\hline Faculty & $\begin{array}{l}\text { Number of } \\
\text { Responses }\end{array}$ & $\begin{array}{l}\text { Actual } \\
\text { Number }\end{array}$ & $\begin{array}{c}\text { Percent of } \\
\text { Actual }\end{array}$ & $\begin{array}{c}\text { Percent of } \\
\text { Respondents }\end{array}$ \\
\hline \multicolumn{5}{|l|}{ By Rank: } \\
\hline Full professor & 30 & 130 & $23.1 \%$ & $31.3 \%$ \\
\hline Associate Professor & 38 & 81 & $50.0 \%$ & $39.6 \%$ \\
\hline Lecturer & 25 & 42 & $60.0 \%$ & $26.0 \%$ \\
\hline Assistant & 3 & 3 & $100 \%$ & $3.1 \%$ \\
\hline Total All Ranks: & 96 & 256 & $37.5 \%$ & $100 \%$ \\
\hline \multicolumn{5}{|l|}{ By Age: } \\
\hline 20-29 years old & 1 & 2 & $50.0 \%$ & $1.0 \%$ \\
\hline $30-39$ years old & 25 & 40 & $62.5 \%$ & $26.0 \%$ \\
\hline 40-49 years old & 27 & 74 & $36.5 \%$ & $28.1 \%$ \\
\hline $50-59$ years old & 33 & 98 & $33.7 \%$ & $34.4 \%$ \\
\hline 60 years old or older & 10 & 42 & $23.8 \%$ & $10.4 \%$ \\
\hline Total All Ages: & 96 & 256 & $37.5 \%$ & $100 \%$ \\
\hline \multicolumn{5}{|l|}{ By Service: } \\
\hline less than three years & 8 & $\mathrm{~N} / \mathrm{A}$ & - & $8.3 \%$ \\
\hline three to five years & 14 & $\mathrm{~N} / \mathrm{A}$ & - & $14.6 \%$ \\
\hline six to fifteen years & 31 & $\mathrm{~N} / \mathrm{A}$ & - & $32.3 \%$ \\
\hline sixteen years of more & 43 & $\mathrm{~N} / \mathrm{A}$ & - & $44.8 \%$ \\
\hline Total All Years of Service: & 96 & 256 & - & $100 \%$ \\
\hline
\end{tabular}

cases, especially at the older and larger traditional universities, the senior faculty will even rule over the chair (Arimoto, 1993). For this reason, it was surprising that the survey did not receive a larger number of senior faculty respondents given that Japan has traditionally been a society where the younger members 
must defer to their elders and are seldom involved in decision-making, or even willing to comment about decision-making. In fact, a review of the surveys showed that few of the junior faculty respondents had ever held a major position of governance at Toshi University or even served on any university-wide committees. Given the traditional Japanese cultural context, it would stand to reason to expect a much lower return from these junior faculty members who might feel it inappropriate to reply to a survey that deals with governance and authority. On the other hand, the survey results may be a reflection of a recent trend in Japan in which the younger members of Japanese society are beginning to demand more participation in decision-making. This trend is widely reported in the popular media in reference to the new generation of corporate workers in Japan who are becoming increasingly out-spoken and demanding. Indeed, the higher education world may be experiencing similar changes where the younger faculty member is now more willing to voice his or her opinions about governance, even if they are not directly involved in the decision-making process itself.

The survey results did not identify faculty in terms of gender and minority background, but these data were available from Toshi University's Office of Personnel. While female and other minority instructors in higher education have increased over the past decade in Japan, they still play a much more minor role in terms of their participation in the academic profession than in the United States and other Western countries. Japanese colleges and universities also employ fewer teaching staff of foreign citizenship and origin. According to government 
statistics (Ministry of Education, 1998a, Gakko Kihon Chosa Houkokusho), only $12.3 \%$ of the university full-time teachers in Japan were female and $3.2 \%$ were classified as foreign citizens. At Toshi University, $12 \%$ of the faculty are female, including 10 Full Professors and 11 Associate Professors. The majority of these female faculty members are teaching in the departments of Education and Foreign Languages. While the number of female faculty is about average for a Japanese university, the number of faculty members who are foreign citizens is much lower. At Toshi University, about $2 \%$ of the faculty are foreign citizens, and all of these faculty members are teaching in the departments of English and American Literature and Foreign Languages, primarily as lecturers. The proportion of female and foreign faculty at Toshi University is much higher among the part-time instructors, where about $33 \%$ are female and $7 \%$ are foreign.

On the following pages, summaries of the responses from each of the three colleges to the first section of the survey are presented (in Tables 3-5). University-wide representation is reflected in the responses, with all ten departments within the university responding. The large number of contacts established by the researcher during his site visit, especially among the chairs and deans, may have accounted for this wide representation in the responses. The highest rate of responses (as percent of actual) was obtained from the Department of Agronomy (68\%). The largest number of responses was from the Department of Education with 18 of the 54 faculty members responding. 
Table 3

College of Arts and Education Faculty Respondents by Rank, Age and Service

\begin{tabular}{|c|c|c|c|c|}
\hline Faculty & $\begin{array}{l}\text { Number of } \\
\text { Responses }\end{array}$ & $\begin{array}{c}\text { Number of } \\
\text { Actual }\end{array}$ & $\begin{array}{c}\text { Percent of } \\
\text { Actual }\end{array}$ & $\begin{array}{l}\text { Percent of } \\
\text { Respondents }\end{array}$ \\
\hline \multicolumn{5}{|l|}{ By Department: } \\
\hline Education & 18 & 54 & $33.3 \%$ & $41.9 \%$ \\
\hline Drama \& Fine Arts & 7 & 33 & $21.2 \%$ & $16.3 \%$ \\
\hline English and Am. Lit. & 5 & 29 & $17.2 \%$ & $11.6 \%$ \\
\hline Foreign Languages & 13 & 34 & $38.2 \%$ & $30.2 \%$ \\
\hline Total All Departments & 43 & 141 & $30.5 \%$ & $100 \%$ \\
\hline \multicolumn{5}{|l|}{ By Rank: } \\
\hline Full professor & 11 & 70 & $15.7 \%$ & $25.6 \%$ \\
\hline Associate Professor & 17 & 41 & $41.5 \%$ & $39.5 \%$ \\
\hline Lecturer & 13 & 28 & $46.4 \%$ & $30.2 \%$ \\
\hline Assistant & 2 & 2 & $100 \%$ & $4.7 \%$ \\
\hline Total All Faculty & 43 & 141 & $30.5 \%$ & $100 \%$ \\
\hline \multicolumn{5}{|l|}{ By Age: } \\
\hline 20-29 years old & 1 & 2 & $50.0 \%$ & $2.3 \%$ \\
\hline 30-39 years old & 10 & 21 & $47.6 \%$ & $23.2 \%$ \\
\hline 40-49 years old & 12 & 40 & $30,0 \%$ & $27.9 \%$ \\
\hline $50-59$ years old & 15 & 50 & $30.0 \%$ & $34.8 \%$ \\
\hline 60 years old or older & 5 & 28 & $17.9 \%$ & $11.6 \%$ \\
\hline Total All Ages & 43 & 141 & $30.5 \%$ & $100 \%$ \\
\hline \multicolumn{5}{|l|}{ By Years of Service: } \\
\hline less than three years & 4 & $\mathrm{~N} / \mathrm{A}$ & - & $9.3 \%$ \\
\hline three to five years & 3 & $\mathrm{~N} / \mathrm{A}$ & - & $7.0 \%$ \\
\hline six to fifteen years & 16 & $\mathrm{~N} / \mathrm{A}$ & - & $37.2 \%$ \\
\hline sixteen years of more & 20 & $\mathrm{~N} / \mathrm{A}$ & - & $46.5 \%$ \\
\hline Total Service: & 43 & 141 & - & $100 \%$ \\
\hline
\end{tabular}


Table 4

College of Agriculture Faculty Respondents by Rank, Age and Service

\begin{tabular}{|c|c|c|c|c|}
\hline Faculty & $\begin{array}{l}\text { Number of } \\
\text { Responses }\end{array}$ & $\begin{array}{c}\text { Number of } \\
\text { Actual }\end{array}$ & $\begin{array}{c}\text { Percent of } \\
\text { Actual }\end{array}$ & $\begin{array}{c}\text { Percent of } \\
\text { Respondents }\end{array}$ \\
\hline \multicolumn{5}{|l|}{ By Department: } \\
\hline Agronomy & 17 & 25 & $68.0 \%$ & $70.8 \%$ \\
\hline Agriculture Chemistry & 7 & 17 & $41.2 \%$ & $29.7 \%$ \\
\hline Total All Departments: & 24 & 42 & $57.1 \%$ & $100 \%$ \\
\hline \multicolumn{5}{|l|}{ By Rank: } \\
\hline Full professor & 7 & 15 & $46.7 \%$ & $29.7 \%$ \\
\hline Associate Professor & 6 & 14 & $42.9 \%$ & $25.0 \%$ \\
\hline Lecturer & 10 & 12 & $83.3 \%$ & $41.7 \%$ \\
\hline Assistant & 1 & 1 & $100 \%$ & $4.7 \%$ \\
\hline Total All Ranks: & 24 & 42 & $57.1 \%$ & $100 \%$ \\
\hline \multicolumn{5}{|l|}{ By Age: } \\
\hline 20-29 years old & 0 & 0 & -- & -- \\
\hline 30-39 years old & 9 & 12 & $75.0 \%$ & $37.5 \%$ \\
\hline 40-49 years old & 6 & 13 & $46.2 \%$ & $25.0 \%$ \\
\hline $50-59$ years old & 8 & 14 & $57.4 \%$ & $33.3 \%$ \\
\hline 60 years old or older & 1 & 3 & $33.3 \%$ & $4.7 \%$ \\
\hline Total All Ages: & 24 & 42 & $57.1 \%$ & $100 \%$ \\
\hline \multicolumn{5}{|l|}{ By Years of Service: } \\
\hline less than three years & 3 & $\mathrm{~N} / \mathrm{A}$ & - & $12.5 \%$ \\
\hline three to five years & 5 & $\mathrm{~N} / \mathrm{A}$ & - & $20.8 \%$ \\
\hline six to fifteen years & 8 & $\mathrm{~N} / \mathrm{A}$ & - & $33.3 \%$ \\
\hline sixteen years of more & 8 & $\mathrm{~N} / \mathrm{A}$ & - & $33.3 \%$ \\
\hline Total Service: & 24 & 42 & - & $100 \%$ \\
\hline
\end{tabular}


Table 5

College of Engineering Faculty Respondents by Rank, Age and Service

\begin{tabular}{|c|c|c|c|c|}
\hline Faculty & $\begin{array}{l}\text { Number of } \\
\text { Responses }\end{array}$ & $\begin{array}{c}\text { Number of } \\
\text { Actual }\end{array}$ & $\begin{array}{c}\text { Percent of } \\
\text { Actual }\end{array}$ & $\begin{array}{c}\text { Percent of } \\
\text { Respondents }\end{array}$ \\
\hline \multicolumn{5}{|l|}{ By Department: } \\
\hline Mechanical Eng. & 10 & 20 & $50.0 \%$ & $34.5 \%$ \\
\hline Electronic Eng. & 4 & 17 & $23.5 \%$ & $13.8 \%$ \\
\hline Information-Comm. & 7 & 18 & $38.9 \%$ & $24.1 \%$ \\
\hline Management Eng. & 8 & 18 & $44.4 \%$ & $27.6 \%$ \\
\hline Total All Departments: & 29 & 73 & $39.7 \%$ & $100 \%$ \\
\hline \multicolumn{5}{|l|}{ By Rank: } \\
\hline Full professor & 12 & 45 & $26.7 \%$ & $41.4 \%$ \\
\hline Associate Professor & 15 & 26 & $57.7 \%$ & $51.7 \%$ \\
\hline Lecturer & 2 & 2 & $100 \%$ & $6.9 \%$ \\
\hline Assistant & 0 & 0 & -- & -- \\
\hline Total All Ranks: & 29 & 73 & $39.7 \%$ & $100 \%$ \\
\hline \multicolumn{5}{|l|}{ By Age: } \\
\hline 20-29 years old & 0 & 0 & -- & -- \\
\hline 30-39 years old & 6 & 7 & $86.7 \%$ & $20.7 \%$ \\
\hline 40-49 years old & 9 & 21 & $42.9 \%$ & $31.0 \%$ \\
\hline $50-59$ years old & 10 & 34 & $29.4 \%$ & $34.5 \%$ \\
\hline 60 years old or older & 4 & 11 & $36.4 \%$ & $13.8 \%$ \\
\hline Total All Ages: & 29 & 73 & $39.7 \%$ & $100 \%$ \\
\hline \multicolumn{5}{|l|}{ By Years of Service: } \\
\hline less than three years & 1 & $\mathrm{~N} / \mathrm{A}$ & - & $3.4 \%$ \\
\hline three to five years & 6 & $\mathrm{~N} / \mathrm{A}$ & - & $20.7 \%$ \\
\hline six to fifteen years & 7 & $\mathrm{~N} / \mathrm{A}$ & - & $24.1 \%$ \\
\hline sixteen years of more & 15 & $\mathrm{~N} / \mathrm{A}$ & - & $51.8 \%$ \\
\hline Total Service: & 29 & 73 & - & $100 \%$ \\
\hline
\end{tabular}


Faculty in Administrative Positions of Governance. Some of the faculty members at Toshi University are important decision-makers, especially those who serve in important positions of authority. According to the survey results, faculty members at Toshi University serve as chairs of departments, administrators of programs or projects, deans of colleges, coordinators of curriculum and directors of institutes or centers.

About one-third of the respondents from the three colleges (33 of the 96) indicated that they had served in a position of administration at Toshi University. Faculty respondents serving in positions of governance was highest in the College of Agriculture, followed by the College of Arts and Education, and College of Engineering. Some of the respondents indicated that they had held more than one position of governance, so there were actually 33 respondents for 38 positions. As shown in Table 6, among those faculty members who did indicate that they had held a position of governance at Toshi University, the most frequently mentioned positions were: chair of a department (39\%), administrator of a program or project (24\%), dean of a college (16\%), coordinator of curriculum (13\%), and director of an institute or center (8\%).

The survey results (Table 6) indicate that the average time served in a single position of governance or administration at Toshi University was about four years. The tendency for the dean of a college, the director of an institute, or the chair of a department was to serve from three to four years. Those respondents who reported that they had served as an administrator of a program or project varied much more with regard to their years of service, but the average was 


\section{Table 6}

\section{All Faculty Serving in Governance Positions}

\begin{tabular}{lccc}
\hline $\begin{array}{c}\text { Type of Position } \\
\mathrm{N}=38\end{array}$ & $\begin{array}{c}\text { Number of } \\
\text { Positions }\end{array}$ & $\begin{array}{c}\text { Percent of } \\
\text { Positions }\end{array}$ & $\begin{array}{c}\text { Avg. Years } \\
\text { of Service }\end{array}$ \\
\hline College Dean & 6 & 15.78 & 3.3 \\
Institute/Center Director & 3 & 07.89 & 3.7 \\
Department Chair & 15 & 39.47 & 3 \\
Administrator & 9 & 23.68 & 4.3 \\
Curriculum Coordinator & 5 & 13.15 & 6.4 \\
Total & 38 & $100 \%$ & 4.1 \\
\hline
\end{tabular}

around four years. Some of the areas of administration mentioned included the management of a museum, an audio-visual information center, a library and a college entrance examination. Coordinators of curriculum tended to serve the longest, averaging over six years in that position.

The positions of Dean, Director and Chair are some of the most important decision-making positions at Toshi University; over $20 \%$ of the survey respondents indicated that they had served in one of those roles. All of the faculty who indicated that they had served in these decision-making positions were either associate or full professors who were 40 years or older with over six years of total service at Toshi University. In addition, over $80 \%$ of this elite group of respondents were full professors who were 50 years or older with over 16 years of total service at the University. These results clearly demonstrate that the administrative and governance roles at Toshi University are largely restricted to the most senior full professors with long years of service at the University. 
Note that none of the respondents had indicated that they had ever served as a member of the Board of Trustees. This was not surprising given that the researcher interviewed three of the trustee members, including the Chairman, and they probably did not think it would be necessary to also complete a survey.

Collegial Participation in Governance by Faculty. About one-third of the respondents from the three colleges (28 of 96 respondents) indicated that they had involvement on one or more of the university-wide committees. These committees, which have a limited decision-making capacity and are mostly advisory in nature, do not include the college or department-level Faculty Council that all faculty at Toshi University are members of within their respective department and college. Participation in these university-wide committees by survey respondents was highest in the College of Arts and Education, followed by the College of Agriculture, and College of Engineering. Some of the respondents indicated that they had served on more than one committee, so there were actually 28 respondents for 31 committee positions. As shown in Table 7, the most frequently mentioned number of years a faculty member serves in a committee position was two years, with over $40 \%$ of the respondents reporting this number. The types of university-wide committees most frequently mentioned were Future Planning Committees, Federation Council, Curriculum Committees, Faculty Affairs Committees, Library Committees and Student Affairs Committees. 


\section{Table 7}

\section{All Faculty Involvement on Committees}

\begin{tabular}{lccc}
\hline \multicolumn{1}{c}{$\begin{array}{c}\text { Type of Committee } \\
\mathrm{N}=31\end{array}$} & $\begin{array}{c}\text { Number of } \\
\text { Faculty }\end{array}$ & $\begin{array}{c}\text { Percent of } \\
\text { Committees }\end{array}$ & $\begin{array}{c}\text { Years of } \\
\text { Service }\end{array}$ \\
\hline Future Planning Committee & 10 & 32.23 & 2 \\
Federation Council & 6 & 19.35 & 1 \\
Curriculum Committees & 4 & 12.90 & varies \\
Faculty Affairs Committees & 4 & 12.90 & 2 \\
Library Committees & 2 & 06.45 & 3 \\
Student Affairs Committees & 2 & 06.45 & varies \\
Instructional Resources Committees & 1 & 03.22 & -- \\
School Establishment Committees & 1 & 03.22 & -- \\
Campus Affairs Committees & 1 & 03.22 & -- \\
Total & 31 & $100 \%$ & 2 \\
\hline
\end{tabular}

As indicated in Table 7, the most frequently mentioned university-wide committee with which faculty reported having any involvement was the Future Planning Committee, representing over $30 \%$ of the committees that faculty reported involvement. The number of years of service indicated for involvement on this committee tended to be around two years. Of the 10 faculty respondents who indicated that they had served on the Future Planning Committee, $70 \%$ reported serving 2 to 3 years. The Academy Council had the second highest number of respondents. Faculty reported serving an average of about 1 to 2 years on the Academy Council. Many of the committees that were mentioned by the faculty respondents dealt with curriculum, faculty affairs and student affairs. Committees addressed a wide range of issues, including multimedia resources, curriculum revision, establishing a new curricula, extracurricular activities, faculty 
procedures, and campus beautification. Subsequent interviews revealed that most of these committee meetings were either sub-committees of the Future Planning Meetings or related to the University-wide Faculty Council.

Faculty Performance Roles. Results from the survey (see Tables 8-11) of all full-time faculty at Toshi University revealed major differences between the three colleges regarding the respective importance faculty assigned to their main activities of teaching, research, service and governance. Faculty members of the College of Arts and Education were more involved in teaching than their colleagues in the College of Agriculture and the College of Engineering. Over $63 \%$ of the faculty respondents in the College of Arts and Education indicated that teaching was the activity where they spent the most amount of time. The percentage was much smaller in the two other colleges, with only $52 \%$ of the respondents in the College of Agriculture and the College of Engineering indicating that teaching was their top activity. In fact, the College of Arts and Education faculty as a group reported that they spent an average of 34.6 hours per week on teaching, lesson preparation, testing, grading, etc. This was much higher than the 19.7 hours per week reported by the respondents in the College of Agriculture and the 24.6 hours per week reported from the College of Engineering. Although the results certainly demonstrate that teaching is an important part of faculty member's daily routine at Toshi University, the actual classroom teaching time is less than that of the average faculty member at a college or university in the United States. 
Table 8

All Faculty Rank Activities According to Amount of Time Spent

\begin{tabular}{ccccccccc}
\hline Rank & Teach & $\begin{array}{c}\text { Avg. } \\
\mathrm{N}=93\end{array}$ & $\begin{array}{c}\text { Res- } \\
\text { earch }\end{array}$ & $\begin{array}{c}\text { Avg. } \\
\text { Hrs }\end{array}$ & Service & $\begin{array}{c}\text { Avg. } \\
\text { Hrs }\end{array}$ & $\begin{array}{c}\text { Gover- } \\
\text { nance }\end{array}$ & $\begin{array}{c}\text { Avg. } \\
\text { Hrs }\end{array}$ \\
\hline$\# 1$ & 53 & 30.6 & 30 & 30.7 & 2 & 17.5 & 8 & 27.5 \\
& $(56.98)$ & & $(32.25)$ & & $(02.15)$ & & $(08.60)$ & \\
$\# 2$ & 38 & 22.7 & 36 & 15.2 & 5 & 15 & 14 & 12 \\
& $(40.86)$ & & $(38.70)$ & & $(05.37)$ & & $(15.05)$ & \\
$\# 3$ & 2 & 17.5 & 22 & 7.9 & 33 & 6.6 & 35 & 8.1 \\
& $(02.15)$ & & $(23.65)$ & & $(35.48)$ & & $(37.63)$ & \\
$\# 4$ & 0 & -- & 5 & 4.5 & 53 & 2.7 & 36 & 2.8 \\
& $(00.00)$ & & $(05.37)$ & & $(56.98)$ & & $(38.70)$ & \\
Total & 93 & 23.6 & 93 & 14.6 & 93 & 10.5 & 93 & 12.6 \\
\hline
\end{tabular}

\section{Table 9}

College of Arts and Education Faculty Rank Activities According to Amount of Time Spent

\begin{tabular}{|c|c|c|c|c|c|c|c|c|}
\hline $\begin{array}{l}\text { Rank } \\
\mathrm{N}=41\end{array}$ & Teach & $\begin{array}{l}\text { Avg. } \\
\text { Hrs }\end{array}$ & $\begin{array}{l}\text { Res- } \\
\text { earch }\end{array}$ & $\begin{array}{l}\text { Avg. } \\
\text { Hrs }\end{array}$ & Service & $\begin{array}{l}\text { Avg. } \\
\text { Hrs }\end{array}$ & $\begin{array}{l}\text { Gover- } \\
\text { nance }\end{array}$ & $\begin{array}{l}\text { Avg. } \\
\text { Hrs }\end{array}$ \\
\hline$\# 1$ & $\begin{array}{c}26 \\
(63.41)\end{array}$ & 32.2 & $\begin{array}{c}9 \\
(21.95)\end{array}$ & 31 & $\begin{array}{c}0 \\
(00.00)\end{array}$ & -- & $\begin{array}{c}6 \\
(14.63)\end{array}$ & 30 \\
\hline \#2 & $\begin{array}{c}15 \\
(36.58)\end{array}$ & 37 & $\begin{array}{c}13 \\
(31.70)\end{array}$ & 13.8 & $\begin{array}{c}3 \\
(07.31)\end{array}$ & 15 & $\begin{array}{c}10 \\
(24.39)\end{array}$ & 17 \\
\hline \#3 & $\begin{array}{c}0 \\
(00.00)\end{array}$ & -- & $\begin{array}{c}18 \\
(43.90)\end{array}$ & 8.3 & $\begin{array}{c}11 \\
(26.82)\end{array}$ & 9.3 & $\begin{array}{c}11 \\
(26.82)\end{array}$ & 11 \\
\hline$\# 4$ & $\begin{array}{c}0 \\
(00.00)\end{array}$ & -- & $\begin{array}{c}1 \\
(02.43)\end{array}$ & -- & $\begin{array}{c}27 \\
(65.85)\end{array}$ & 2.7 & $\begin{array}{c}14 \\
(34.14)\end{array}$ & 3.3 \\
\hline Total & 41 & 34.6 & 41 & 17.7 & 41 & 9 & 41 & 15.3 \\
\hline
\end{tabular}


Table 10

College of Agriculture Faculty Rank Activities According to Amount of

Time Spent

\begin{tabular}{ccccccccc}
\hline Rank & Teach & $\begin{array}{c}\text { Avg. } \\
\text { N=23 }\end{array}$ & $\begin{array}{c}\text { Res- } \\
\text { earch }\end{array}$ & $\begin{array}{c}\text { Avg. } \\
\text { Hrs }\end{array}$ & Service & $\begin{array}{c}\text { Avg. } \\
\text { Hrs }\end{array}$ & $\begin{array}{c}\text { Gover- } \\
\text { nance }\end{array}$ & $\begin{array}{c}\text { Avg. } \\
\text { Hrs }\end{array}$ \\
\hline$\# 1$ & 12 & 27.2 & 10 & 34.4 & 1 & 15 & 0 & -- \\
& $(52.17)$ & & $(43.47)$ & & $(04.34)$ & & $(00.00)$ & \\
$\# 2$ & 9 & 14.4 & 9 & 14.7 & 2 & 15 & 3 & 4 \\
& $(39.13)$ & & $(39.13)$ & & $(08.69)$ & & $(13.04)$ & \\
$\# 3$ & 2 & 17.5 & 2 & -- & 7 & 5 & 12 & 6.1 \\
& $(08.69)$ & & $(08.69)$ & & $(30.43)$ & & $(52.17)$ & \\
$\# 4$ & 0 & -- & 2 & 4 & 13 & 3.38 & 8 & 2.9 \\
& $(00.00)$ & & $(08.69)$ & & $(56.52)$ & & $(34.78)$ & \\
Total & 23 & 19.7 & 23 & 17.7 & 23 & 9.6 & 23 & 4.3 \\
\hline
\end{tabular}

Table 11

College of Engineering Faculty Rank Activities According to Amount of

Time Spent

\begin{tabular}{|c|c|c|c|c|c|c|c|c|}
\hline $\begin{array}{l}\text { Rank } \\
\mathrm{N}=29\end{array}$ & Teach & $\begin{array}{c}\text { Avg. } \\
\text { Hrs }\end{array}$ & $\begin{array}{l}\text { Res- } \\
\text { earch }\end{array}$ & $\begin{array}{c}\text { Avg. } \\
\text { Hrs }\end{array}$ & Service & $\begin{array}{c}\text { Avg. } \\
\text { Hrs }\end{array}$ & $\begin{array}{l}\text { Gover- } \\
\text { nance }\end{array}$ & $\begin{array}{l}\text { Avg. } \\
\text { Hrs }\end{array}$ \\
\hline$\# 1$ & $\begin{array}{c}15 \\
(51.72)\end{array}$ & 32.3 & $\begin{array}{c}11 \\
(37.93)\end{array}$ & 24.6 & $\begin{array}{c}1 \\
(03.44)\end{array}$ & 20 & $\begin{array}{c}2 \\
(06.89)\end{array}$ & 25 \\
\hline \#2 & $\begin{array}{c}14 \\
(48.27)\end{array}$ & 16.8 & $\begin{array}{c}14 \\
(48.27)\end{array}$ & 17 & $\begin{array}{c}0 \\
(00.00)\end{array}$ & -- & $\begin{array}{c}1 \\
(03.44)\end{array}$ & 15 \\
\hline \#3 & $\begin{array}{c}0 \\
(00.00)\end{array}$ & -- & $\begin{array}{c}2 \\
(06.89)\end{array}$ & 7.5 & $\begin{array}{c}15 \\
(51.72)\end{array}$ & 5.5 & $\begin{array}{c}12 \\
(41.37)\end{array}$ & 7.1 \\
\hline \#4 & $\begin{array}{c}0 \\
(00.00)\end{array}$ & -- & $\begin{array}{c}2 \\
(06.89)\end{array}$ & 5 & $\begin{array}{c}13 \\
(44.82)\end{array}$ & 1.9 & $\begin{array}{c}14 \\
(48.27)\end{array}$ & 2.3 \\
\hline Total & 29 & 24.6 & 29 & 13.5 & 29 & 9.1 & 29 & 12.4 \\
\hline
\end{tabular}


According to the Director of Personnel at Toshi University, full-time faculty members are expected to have a physical presence on the campus five days per week and teach five courses. Each course meets 100-minutes per week, either as one 100-minute class meeting or two 50-minute class meetings. (Faculty members in the College of Arts and Education must be on the campus at least four days per week, but also teach five courses that meet for a total of 500 minutes per week.) The survey results indicate that a faculty member in the College of Arts and Education spends as much as twenty hours per week on lesson preparation, grading and other instruction-related duties.

According to Arimoto (1993), the university faculty in Japan tends to emphasize research in their daily activities, and most of them belong to three or four professional and academic associations in various disciplines. Teichler (1997) points to a 1992 international study that reported that Japanese faculty actually spend a higher proportion of their time on research than their colleagues in the United States and selected European countries, including Germany. According to the results of the survey (see Table 8), full-time faculty members at Toshi University average about 15 hours per week for research. Faculty members in the College of Agriculture and College of Engineering were much more oriented to research than their colleagues in the College of Arts and Education. Over $43 \%$ of the faculty respondents from the College of Agriculture and about 38\% from the College of Engineering indicated that they spent most of their time on research, much higher than the College of Arts and Education, 
where $21 \%$ of the faculty respondents reported that research was their top activity.

Respondents from all three colleges reported giving the least amount of time to service, about 10 hours per week (see Table 8). In the United States, public service is one of the criterion by which faculty members are evaluated for tenure and promotion; this is not always the case in Japan. At Toshi University, the progression of a faculty member from Lecturer or Assistant to Associate Professor or Full Professor is dependent on his or her qualifications (e.g. academic degree), age and years of service. According to the Director of the Office of Personnel at Toshi University, each faculty member seeking tenure is evaluated once every five years by the Faculty Evaluation Committee (kyooin shikaku shinsa iinkai). This committee makes recommendations to the President with regard to promotion and prepares a report on the faculty member's performance in fulfilling his or her teaching and research duties. The teaching and research activities of each faculty member are documented in the Progress Report of Education and Research (kyooiku kenkyuu kyooseki hookokusho), which is submitted to the President and Board of Trustees members each year. The faculty member's record of social service is not considered in the evaluation process. Once faculty receive tenure in Japan, they are virtually guaranteed job security until mandatory retirement at sixty-five.

In addition to teaching and conducting research, faculty members also spend a lot of time participating in faculty meetings and performing administrative chores. One faculty member indicated that he spent as much as 10 hours per 
week in Faculty Council meetings alone. As a group, the faculty at Toshi University reported that they spend about 13 hours per week on governancerelated activities (see Table 8 ). Over $20 \%$ of the faculty members ranked governance as their first or second top activity. This is not surprising given that most of these same respondents also indicated that they were serving in administrative positions. However, note that all of the full-time faculty members at Toshi University are involved in the decision-making process, at least indirectly, as a result of the School Education Law and their membership in a Faculty Council. The School Education Law requires that every university set up Faculty Council meetings to discuss important matters, including recruitment of new faculty members, and that these meetings be open not only to full professors, but also associate professors and other academic staff. The law also requires that the President base his or her selection of faculty, including teaching staff and deans, on the decisions made in these meetings.

The survey results further reveal that faculty members at Toshi University spend an average of 61.3 hours per week on teaching, research, service and governance activities. This time does not reflect the long commutes that are typical in metropolitan Japan where one might average ten to fifteen hours per week travelling to and from work by train. While in the past, Japan led the world's work force in number of working hours, in recent years this number has been reduced considerably. According to the Japanese Ministry of Labor statistics for 1997, the average annual working hours was 1,900 (or about 7 hours and 41 minutes per day). In the United States, the figure for the same year 
was 1,986 hours. In spite of this trend, faculty members at Toshi University work much longer hours. These statistics from the Ministry of Labor, however, are more reflective of the manufacturing and service industries, and may not hold true for university faculty. Moreover, other studies have investigated the working conditions of university faculty in Japan and also discovered similar findings to the results in this study (Barretta, 1987). Also, many of the respondents experienced difficulty completing this section of the survey. Several commented that they found it difficult to estimate the amount of time they spent on each activity (in addition to ranking its relative importance) and over one-third did not estimate the hours spent in each activity at all. Other respondents estimated the number of hours spent per day or per month, instead of per week as was instructed on the survey.

Faculty Attitudes toward the Past Reforms. Faculty and administrators at private and public universities in Japan have been forced to re-examine their teaching and research activities in response to the 1991 and 1996 University Council reforms. Faculty are just beginning to react to the 1998 University Council reforms. All of these recent reforms are the product of at least four major trends, including (1) decreases in the traditional college-going cohort, (2) internationalization, (3) decreases in government subsidies and, (4) an increasingly competitive job marketplace that students must face upon graduation. Higher education institutions in Japan, both private and public, are increasingly more market-driven and are forced to respond to these trends. At Toshi University, curriculum reforms are being carried out in all three of its 
colleges with the goal, as the Director of Admissions at Toshi University stated in an interview, of "setting Toshi University apart from other colleges in Japan."

The most significant changes to the curriculum during the past five years were revisions to the general education requirements. According to the President of Toshi University, these revisions were carried out by faculty members from each college and department. The reforms were primarily based on the Liberal Arts model found in the United States, where all students must satisfy a general education requirement before they begin to take courses in their major. The changes were applied equally to all of the four-year degree programs at Toshi University, and all students are now required to select courses from among five areas of study to be distributed evenly. Some characteristics of the curriculum are unique to Toshi University. For example, during the first year, students must take six credit hours of courses that promote an educational philosophy that was espoused by the founder of Toshi University. The President also initiated a change soon after becoming president that required departments to standardize their specialized curriculum based on the content of the program. Before that time, the requirements for the major areas of study were much less standardized and were more dependent on who taught the courses, rather than what was being taught. According to the President of Toshi University,

Before, we had influential faculty members who primarily determined which courses in the major were requirements depending on what courses they preferred to teach. The courses taught by influential faculty members became the required courses and the courses taught by other less 
influential faculty members became the elective courses. (Personal Communication, June 1999)

Numerous other changes have occurred during the past five years, many of which were facilitated by government reforms. The most significant among these prior to the 1998 University Council reforms were the 1991 University Council reforms. The 1991 reforms made it possible for public and private universities to establish their own curriculum and even abandon the two-stage undergraduate education system if they wished. Prior to 1991, all universities in Japan were required to offer a two-year general education course consisting of humanities, social sciences and natural sciences and, during the final two-years, students could specialize and select a major. Many consider the recent reform recommendations by the University Council as a response to the widespread criticism of Japan's higher education system. Japanese universities are often characterized as hard to enter but relatively easy to graduate from, populated with professors who deliver "one-way" lectures and give inflated grades to students who merely pass exams, but rarely study or attend the lectures. These concerns about academic quality were summarized in a report commissioned by the United States Department of Education and prepared by a cooperative U.S.Japan study team. The report concluded that higher education was the weakest part of the entire Japanese educational system (Dorfman, 1987).

According to the 2000 Toshi University Student Bulletin, major curricular reforms at Toshi University were implemented in 1995, one year after the current president began his tenure and three years after the 1991 University Council 
reforms that relaxed Ministry control over curriculum. One of the most widespread of these changes was the implementation of a more flexible course schedule that was adopted by each of the three colleges at Toshi University. Before that, students were required to follow a rigid daily schedule with each course meeting for 100 minutes, once per week, without any break. Toshi University now offers a greater variety of formats for course meetings, and most courses now meet for 50 minutes, twice per week. Courses are also offered throughout the day and allow for individualized scheduling by students. In addition to more flexible scheduling, the three colleges have also implemented a semester system and students now register twice per year to take courses -- at the beginning of April and again in September. Because of the changes in the semester system and course scheduling format, the curriculum itself has changed to become more flexible and integrated. According to the Student Bulletin, the upper-level curriculum at Toshi University is now more integrated between the three colleges. For example, students in the International Business Management program in the College of Arts and Education are able to take some of their major-level courses in the College of Engineering, and students in the College of Engineering can cross-register for courses in the College of Arts and Education.

On the survey, faculty members were asked to rank the top three changes during the past five years at Toshi University affecting their teaching, research and other duties. Included in the items were typical changes occurring throughout Japan at other colleges and universities as reported by the Ministry of 
Education in its most recent assessment of the 1991 University Council reforms. For example, since the mid-1990's, increasing numbers of universities have established new centers for developing education methods and providing training for teaching staff in order to improve class content and teaching methods. As of 1995, 51 universities had developed training seminars for new teaching staff, 11 universities had developed policies for mutual class observation by teaching staff and 23 universities had established new centers for developing education methods (Ministry of Education, 1996). Also, dramatically increasing is the number of universities requiring the faculty to prepare and distribute syllabi for their classes and to have students evaluate their classes. Another recent change has been the introduction of the teaching assistant system in the Japanese universities. Teaching assistants in Japan are usually postgraduate students who teach or conduct research under the guidance of full-time academic staff. In 1994, 23,688 teaching assistants taught in 246 universities, and this number has been increasing (Ministry of Education, 1996).

As indicated in Table 12, the requirement that all faculty must prepare and distribute syllabi for the classes they teach was reported to be the biggest change at Toshi University during the past five years, with $75 \%$ of the respondents specifying this item as the top change. This new requirement was also met with some opposition. According to one faculty member who provided no further explanation, "the increased use of syllabi in our classes has had no pedagogical effect." Because of the large number of faculty respondents who did not indicate any of the other changes, it is assumed that either those other 
changes have not been widely implemented at Toshi University, or they are changes that were implemented longer than five years ago.

\section{Table 12}

\section{All Faculty Specify the Top Three Changes During the Past Five Years at} Toshi University Affecting their Teaching, Research and Other Duties

\begin{tabular}{lcc}
\hline \multicolumn{1}{c}{$\begin{array}{c}\text { Changes } \\
\mathrm{N}=96\end{array}$} & $\begin{array}{c}\text { Top Three } \\
\text { Change }\end{array}$ & Not Chosen \\
\hline Faculty participation in the self-evaluation of the & 11 & 85 \\
University & $(11.45)$ & \\
\hline Establishment of a new center for developing & 28 & 68 \\
education methods & $(29.16)$ & \\
\hline Training opportunities for the teaching staff & 17 & 79 \\
& $(17.70)$ & \\
\hline Requirement of the faculty to prepare and distribute & 72 & 24 \\
syllabi for the classes they teach & $(75.00)$ & \\
\hline Requirement of the faculty to have their students & 23 & 73 \\
evaluate the classes they teach & $(23.95)$ & \\
\hline Increasing usage of Teaching Assistants & 16 & 80 \\
& $(16.66)$ & \\
\hline
\end{tabular}

Many of the faculty respondents made additional comments on this part of the survey. Some of the major changes they reported included (1) increased use of computers, (2) increased administrative duties for faculty, (3) the establishment of a semester system, (4) limitations on the number of credits students are now allowed to carry each semester, and (5), (the most frequently mentioned change) the reduction of faculty and larger class sizes. The President of Toshi University also indicated that the number of faculty is being reduced 
because of declines in student numbers. According to the President, the student-teacher ratio at Toshi University is currently 1:24, compared to the average of 1:40. A few of the faculty at Toshi University are also concerned that more and more teaching positions will be filled by part-time instructors, instead of full professors. These trends of larger class sizes and increased use of part-time teachers are not limited to Toshi University, but are becoming increasingly widespread. In fact, the University Council proposed a system of contract appointments in a 1996 report to the Ministry of Education.

The intent of the 1996 University Council recommendation for a system of contract appointments was to promote the flow of academics between universities and government research institutes and private companies, but the proposal was met with severe opposition by faculty members at universities all over Japan. According to Okano \& Tsuchiya (1999), the concerns were threefold. First, the new contract appointment system might end tenure and threaten academic freedom. Secondly, the new system would affect the productivity of faculty members because they would tend to focus on short-term projects, instead of pursuing quality teaching and research. Finally, many faculty members felt that university autonomy would be threatened because the Ministry of Education would eventually be forced to use its funding power to apply pressure to implement the non-compulsory contract appointment system. Despite the widespread opposition, the government passed a bill in June 1997 that established the contract appointment system. Both public and private 
universities have the right not to implement the system, but a few institutions (both public and private) have already begun introducing contract appointments.

The survey results indicate that some faculty members at Toshi University disapprove of the changes that have occurred over the past five years in their college. This dissatisfaction, whether caused by the government reforms or as the result of other trends, is evident in each of the three colleges. Survey results (see Table 13) suggest that many faculty members (average of $40 \%$ ) believe that the changes in the curriculum that have occurred over the past five years in their college have been mostly negative. Faculty respondents were only asked to rate the attitudes of faculty in their college, not university-wide or in other colleges. Perhaps the most striking results came from the College of Arts and Education, where a clear majority of the respondents (58\%) indicated that the attitudes of faculty toward recent changes in the curriculum have been mostly negative in their college. The College of Arts and Education has probably witnessed the most change with regard to its academic programs and instruction. For example, the Department of Education has been standardizing its upper-level division requirements and the Department of English and American Literature is having one of its programs dismantled to provide a base for the new College of Business. On the other hand, the College of Agriculture reported the most positive attitudes toward changes in their department (over 60\%). Interestingly, among the three colleges, the College of Agriculture appears be the least involved in the implementation of substantial reform. 
Table 13

Faculty Rate the Attitudes of Faculty Toward the Changes in the Curriculum that have Occurred Over the Past Five Years in their College

\begin{tabular}{lcccc}
\hline & $\begin{array}{c}\text { Mostly } \\
\text { Positive }\end{array}$ & $\begin{array}{c}\text { Mostly } \\
\text { Negative }\end{array}$ & $\begin{array}{c}\text { No } \\
\text { Opinion }\end{array}$ & $\begin{array}{c}\text { No } \\
\text { Answer }\end{array}$ \\
\hline College of Arts and Education & 12 & 21 & 3 & 7 \\
$\mathrm{~N}=36$ & $(33.33)$ & $(58.33)$ & $(08.33)$ & \\
College of Agriculture & 13 & 5 & 3 & 3 \\
$\mathrm{~N}=21$ & $(61.90)$ & $(23.80)$ & $(14.28)$ & \\
College of Engineering & 16 & 8 & 4 & 1 \\
$\mathrm{~N}=28$ & $(57.14)$ & $(28.57)$ & $(14.28)$ & \\
University-wide & 41 & 34 & 10 & 11 \\
$\mathrm{~N}=85$ & $(48.23)$ & $(40.00)$ & $(11.76)$ & \\
\hline
\end{tabular}

The faculty's role and level of participation in the academic decisionmaking process will certainly have some bearing on the success of the implementation of the government reforms. As one faculty member commented, The government reforms are often unrealistic and most faculty are not interested. The government says it wants to toughen the standards and make it more difficult to graduate, while also making university admission easier. They say this will make the entrance examination obsolete. The government does not understand the reality of the marketplace that private universities must face in Japan. (Personal Communication, June 1999)

Actually, the changing demographics are already making it easier for students to enter universities as the number of 18-year-olds in Japan continues a 
steady decline. The number of university applicants is predicted to match the number of university openings by 2009 , and many higher education institutions are already beginning to experience serious student shortfalls ("Panel Advises," 1998). According to its student bulletin, Toshi University enrolls around 845 firstyear freshman each year in its three colleges. In order to attain that level of enrollment, the University must admit about three times that many students, and an even greater number of students must apply and sit for the entrance examination to ensure a sufficient number of qualified applications from which to choose. As shown in Table 14, in 1999, the top $29.7 \%$ of the pool of applicants who sat for the entrance exam were selected for admission to the University, and in 1998 , the top $20.9 \%$ were selected. In order for Toshi University to continue enrolling the same number of students, it must admit a greater number of less qualified applicants each year. This trend is consistent across the three colleges with the College of Engineering experiencing the most severe problems with regard to admitting acceptable numbers of qualified students.

\section{Table 14}

\section{Comparison of the Number of Applicants and Students Admitted at}

Toshi University in 1999 and 1998

\begin{tabular}{lcccccc}
\hline \multicolumn{1}{c}{ College } & Positions & Applicants & Examined & Admitted & 1999 & 1998 \\
\hline Arts and Education & 465 & 5,301 & 5,025 & 1,320 & $26.3 \%$ & $20.4 \%$ \\
Agriculture & 140 & 1,754 & 1,726 & 464 & $27.0 \%$ & $17.5 \%$ \\
Engineering & 240 & 2,059 & 2,000 & 821 & $41.6 \%$ & $25.0 \%$ \\
Total & 845 & 9,114 & 8,751 & 2,605 & $29.7 \%$ & $20.9 \%$ \\
\hline
\end{tabular}


According to Toshi University's Office of Marketing and Student Recruitment, efforts are now being made to respond to the enrollment trends, primarily related to making the entrance examination more accessible. For example, the exam for admission to programs in the colleges of Agriculture and Engineering is being offered in selected cities around Japan where Toshi University has traditionally been able to recruit students outside of its own prefecture. Also, in order to increase the number of non-traditional students at Toshi University, the entrance examination system was revised in 1999 to include special test-taking times to accommodate the needs of older students who often have busy work schedules and may also be embarrassed to take the exam along side younger students. Despite these various attempts, the number of applications continues to decline with almost $20 \%$ fewer applications each year. Faculty and administrators are concerned that Toshi University will begin to lower its academic standards in order to enroll the same numbers of students as it did in the past. With fewer constraints placed on individual universities by the Ministry of Education, this scenario is likely to have already begun. The President of Toshi University echoes this concern:

As the number of 18 year-olds decline there is the potential that we will be forced to lower our admission standards. As Chairman of the Board of Trustees in charge of finance, I'm tempted to lower the standards in order to enroll more students, but as President in charge of academics, I want to ensure that the academic standards are high. This is one of the dilemmas I'm facing right now. (Personal Communication, June 1999) 
As more and more universities begin to lower their standards, the question of how universities will deal with the influx of students who are not as well prepared for university-level study will become increasingly important. Now, more students are being admitted to Japanese universities who are inadequately prepared and require remedial and developmental education. Also increasing are the numbers of international students and non-traditional aged students, as well as more female students. According to Ministry of Education statistics, since the 1980's, the proportion of females entering higher education exceeded that of males. In the past, females tended to enroll in the junior colleges and less prestigious universities, but this situation is likely to change in the future. According to Ministry of Education statistics, the number of traditional collegegoing students is expected to decrease from its peak of 2.05 million in 1992 to 1.2 million in 2010 (Ministry of Education, 1998b, Monbu tokei yoran). At the same time, in 1997 , as much as $47 \%$ of the 18 -old-cohort were enrolled in universities and junior colleges and, this rate is expected to soon exceed $50 \%$ of the 18-year-old cohort. The diversification and expansion of the college-going population is having an impact on teaching, as illustrated in the following comments from one professor in Toshi University's College of Engineering: ... because we have broadened the base of our enrollment, it has become necessary to provide more support to students who are not prepared for higher education. The teachers must pay more attention to their teaching methods. In the College of Engineering where I am a 
professor, students are encouraged to take elective courses that focus on study skills. (Personal Communication, June 1999)

The government reform measures have been intended to deal with these various problems; however, as the results from the survey indicate (Tables 15 and 16), some faculty perceive that their authority has been weakened by these reforms. About $18 \%$ of the faculty respondents reported that they felt their authority over the curriculum had been weakened, and about $11 \%$ indicated that they felt less empowered over matters related to faculty affairs. On the other hand, most faculty members appear to be cynical and apathetic about the current situation, which might explain the high percentage of respondents, over $50 \%$, who gave no opinions or supplied no answer on these two items of the survey.

\section{Table 15}

Faculty Respondents Indicate whether or not they Agree or Disagree that the Authority of the Faculty over the Curriculum has been Weakened by the Ministry of Education Reforms

\begin{tabular}{lcccc}
\hline \multicolumn{1}{c}{ Questions } & $\begin{array}{c}\text { Mostly } \\
\text { Agree }\end{array}$ & $\begin{array}{c}\text { Mostly } \\
\text { Disagree }\end{array}$ & $\begin{array}{c}\text { No } \\
\text { Opinion }\end{array}$ & $\begin{array}{c}\text { No } \\
\text { Answer }\end{array}$ \\
\hline Arts and Education & 8 & 15 & 12 & 8 \\
$\mathrm{~N}=35$ & $(22.85)$ & $(42.85)$ & $(34.28)$ & \\
Agriculture & 2 & 3 & 17 & 2 \\
$\mathrm{~N}=22$ & $(09.09)$ & $(13.63)$ & $(77.27)$ & \\
Engineering & 5 & 10 & 12 & 2 \\
$\mathrm{~N}=27$ & $(18.51)$ & $(37.03)$ & $(44.44)$ & \\
University-wide & 15 & 28 & 41 & 12 \\
$\mathrm{~N}=84$ & $(17.85)$ & $(33.33)$ & $(48.80)$ & \\
\hline
\end{tabular}


Table 16

Faculty Respondents Indicate whether or not they Agree or Disagree that the Authority of the Faculty over Matters of Faculty Affairs has been

Weakened by the Ministry of Education Reforms

\begin{tabular}{lcccc}
\hline \multicolumn{1}{c}{ Questions } & $\begin{array}{c}\text { Mostly } \\
\text { Agree }\end{array}$ & $\begin{array}{c}\text { Mostly } \\
\text { Disagree }\end{array}$ & $\begin{array}{c}\text { No } \\
\text { Opinion }\end{array}$ & $\begin{array}{c}\text { No } \\
\text { Answer }\end{array}$ \\
\hline Arts and Education & 5 & 15 & 15 & 8 \\
$\mathrm{~N}=35$ & $(14.28)$ & $(42.85)$ & $(42.85)$ & \\
Agriculture & 1 & 5 & 16 & 2 \\
$\mathrm{~N}=22$ & $(04.54)$ & $(22.72)$ & $(72.72)$ & \\
Engineering & 3 & 10 & 14 & 2 \\
$\mathrm{~N}=27$ & $(11.11)$ & $(37.03)$ & $(51.85)$ & \\
University-wide & 9 & 30 & 45 & 12 \\
$\mathrm{~N}=84$ & $(10.71)$ & $(35.71)$ & $(53.57)$ & \\
\hline
\end{tabular}

\section{General Governance Process at Toshi University}

The important organs of governance located within Toshi University are the Board of Trustees, the Academy Council, the Deans' Council, and the Faculty Council. The Ministry of Education is an important external body of governance through its regulatory power over the administration of the University. Toshi University employs 74 full-time administrators, including the president, deans, department chairs and directors of research institutes to oversee the academic affairs of the various schools and departments. Also, 122 full-time administrators and staff provide managerial support through numerous administrative divisions and offices (see Figure 2). The governance process at Toshi University that was revealed through the faculty survey and the interviews with administrators was consistent with the descriptions of governance found in 
Figure 2

\section{Administrative Divisions and Offices at Toshi University}

\section{Division of Academic Affairs}

Office of Academic Affairs and Office of Registrar

\section{Department of Correspondence Education Administration}

\section{Division of Student Affairs}

Office of Student Affairs

\section{Division of Marketing and Student Recruitment}

Office of Marketing and Student Recruitment

\section{Division of Admissions}

Office of Admissions

\section{Placement Center}

Placement Office

\section{Combined Support Group}

Center for International Education, Computer Center, and Health Clinic

\section{Operations \& Management}

Office of Institutional Research, Office of Secretarait, Office of Campus

Affairs, Office of Personnel, Office of Bursar, Office of Property and

Maintenance, and Office of Educational Development

\section{Affiliated Divisions}

This division includes for-profit divisions. 
the school's constitution and by-laws. However, some discrepancies were revealed between how the faculty members perceive the decision-making process as compared to how the faculty and staff that hold an administrative position view the governance process.

According to the interviews with the President, Board of Trustee members, deans, directors and department chairs, important decisions are rarely made in the Faculty Councils, and it is the Board of Trustees and the President that are the most important decision-making bodies. According to Toshi University's Constitution, the Board of Trustees is the final decision-making body at Toshi University with regard to all academic and administrative matters, and the President is expected to carry out his duties according to the recommendations of the Board of Trustees. At Toshi University, the President is also the Chairman of the Board of Trustees, as well as the President of the K-12 schools and the Junior College for Women. The Board of Trustees oversees Toshi University and all of the schools that make up Toshi Academy as a single school corporation. The corporation is owned by the family of the Chairman of the Board of Trustees and is regulated by the Ministry of Education.

Perceptions of the Faculty about University Governance. As shown in Table 17, the faculty survey results paint a slightly different picture of the governance process at Toshi University. The faculty appear to emphasize the importance of the Faculty Council as a decision-making body while deemphasizing the importance of the Board of Trustees and the Deans' Council. On the survey, faculty members were asked to choose which organ of 
governance they were most concerned about: the Ministry of Education, the Board of Trustees, the President, the Deans' Council, the Faculty Council or other bodies, such as the Academy Council.

Table 17

All Faculty Indicate Concern about Decision-making at Various Levels of Governance

\begin{tabular}{lcccc}
\hline \multicolumn{1}{c}{ Decision-making Body } & $\begin{array}{c}\text { Deeply } \\
\text { Concerned }\end{array}$ & $\begin{array}{c}\text { Somewhat } \\
\text { Concerned }\end{array}$ & Indifferent & $\begin{array}{c}\text { No } \\
\text { Answer }\end{array}$ \\
\hline Ministry of Education & 21 & 60 & 1 & 14 \\
$\mathrm{~N}=82$ & $(25.60)$ & $(73.17)$ & $(01.21)$ & \\
Board of Trustees & 6 & 53 & 28 & 9 \\
$\mathrm{~N}=87$ & $(06.89)$ & $(60.91)$ & $(32.18)$ & \\
President & 25 & 61 & 1 & 9 \\
$\mathrm{~N}=87$ & $(28.73)$ & $(70.11)$ & $(01.14)$ & \\
Deans' Council & 18 & 45 & 23 & 10 \\
$\mathrm{~N}=86$ & $(20.93)$ & $(52.32)$ & $(26.74)$ & \\
Faculty Council & 33 & 43 & 6 & 14 \\
$\mathrm{~N}=82$ & $(40.24)$ & $(52.43)$ & $(07.31)$ & \\
\hline
\end{tabular}

It was expected that the faculty respondents would be most concerned about the organ of governance that had the most impact on them and that this would be the body that makes most of the important decisions. According to the results of the survey, the faculty members were most concerned about the decisions made by the Faculty Council, the President, and the Ministry of Education. In fact, a greater proportion of faculty respondents, over $40 \%$, indicated that they were more "deeply" concerned about the decisions made in the Faculty Council meetings than any other body of governance. On the other 
hand, only about $7 \%$ of the respondents reported that they were "deeply" concerned about the Board of Trustees, and over 30\% reported that they were indifferent to the decisions made by the Board of Trustees. About $26 \%$ of the faculty survey respondents reported that they were indifferent to the Deans' Council and very few faculty members noted a concern about the decisions made by the Academy Council (although this was not one of the items on the survey).

One faculty respondent noted on his survey that "depending on the level of governance, the system of decision-making on this campus is unclear." At least from the perspective of the faculty, the administrative decision-making structure at Toshi University is more ambiguous and fluid than the academic governance process. For example, many of the faculty members interviewed were aware of the basic organizational structure of Toshi University, but the position titles and responsibilities of the people who head the various administrative departments and divisions were not as clearly understood. In fact, the researcher was unable to find any written descriptions of the duties and responsibilities for most of the administrative positions, although the constitution and by-laws of Toshi University provides some limited description of the governance structure. There was also discrepancies between some of the organizational charts maintained by Toshi University Office of Personnel. For example, in comparing two organizational charts used by the researcher, a Japanese version and an English version, one of the organizational charts describes the Office of Secretariat as being under the Office of the President and 
another chart describes this office as being under the Divisions of Operations \& Management. Such contradictory descriptions would obviously contribute to the confusion, even among the faculty and staff themselves, about the organization of administrative authority at Toshi University.

As illustrated in Table 18, the faculty at Toshi University consider control by the Ministry of Education to be at its highest in the area of academic programs and instruction. About $19 \%$ of all of the faculty respondents indicated that the Ministry of Education had "too much control" in the academic decision-making at Toshi University and 13\% reported that the Ministry had "too much control" over the financial affairs of their institution. Control by the Ministry was perceived to be highest in matters of academic programs, followed by financial affairs, faculty affairs and relationship with the external environment.

\section{Table 18}

All Faculty Indicate Opinions about Ministry of Education's Control Over the Various Functions on Decision-making at Toshi University

\begin{tabular}{lcccc}
\hline $\begin{array}{l}\text { Functions of } \\
\text { Governance }\end{array}$ & $\begin{array}{c}\text { Too Much } \\
\text { Control }\end{array}$ & $\begin{array}{c}\text { Not Much } \\
\text { Control }\end{array}$ & $\begin{array}{c}\text { No } \\
\text { Opinion }\end{array}$ & $\begin{array}{c}\text { No } \\
\text { Answer }\end{array}$ \\
\hline Academic Affairs & 17 & 34 & 39 & 6 \\
$\mathrm{~N}=90$ & $(18.88)$ & $(37.77)$ & $(43.33)$ & \\
Financial Affairs & 12 & 36 & 42 & 6 \\
$\mathrm{~N}=90$ & $(13.33)$ & $(40.00)$ & $(46.66)$ & \\
Faculty Affairs & 7 & 40 & 43 & 6 \\
$\mathrm{~N}=90$ & $(07.77)$ & $(44.44)$ & $(47.77)$ & \\
External Affairs & 4 & 44 & 41 & 7 \\
$\mathrm{~N}=89$ & $(04.49)$ & $(49.43)$ & $(46.06)$ & \\
\hline
\end{tabular}


The survey results reported in Table 19 show that many faculty members at Toshi University are also unfamiliar with the strong external pressure exerted by the Ministry of Education in Japan over the decision-making process at their institution. This situation was reflected in the large number of survey respondents who did not answer or gave no opinion to those items on the survey that asked about the role of the Ministry of Education in the governance process at Toshi University. Some of these faculty respondents made additional comments on the survey admitting that they were not well informed about the relationship between the Ministry of Education and their school and were unable to answer the questions. These comments would suggest that many of the faculty members at Toshi University lack experience in dealing with the Ministry and are unfamiliar with the relationship between the Ministry of Education and Toshi University. Of those who did answer the questions, the majority of the faculty, about $77 \%$ of the respondents, indicated that the Ministry of Education's role in the decision-making was very limited. Several faculty members noted on their survey that Toshi University is private, not public, and therefore, the Ministry of Education has little control over their University. Another faculty respondent indicated that the Ministry of Education's control has been weakened due to recent higher education reforms in Japan. About $23 \%$ of the respondents indicated that they think the Ministry of Education still exerts "too much" influence over the decision-making at their school. One faculty member noted on his survey that the Ministry of Education "has exerted too much control with regard to 
academic credit and hours issues and we are forced to decrease the classes that are necessary for our students."

\section{Table 19}

Faculty Opinions about Ministry of Education's Control Over Decisionmaking at Toshi University

\begin{tabular}{lccc}
\hline $\begin{array}{l}\text { Question: Do you think the Ministry of Education } \\
\text { exerts too much control over decision-making at }\end{array}$ & & No & N/A \\
Toshi University? & & & \\
\hline College of Arts and Education & 4 & 28 & 11 \\
$\mathrm{~N}=32$ & $(12.50)$ & $(87.50)$ & \\
College of Agriculture & 4 & 17 & 3 \\
$\mathrm{~N}=21$ & $(19.04)$ & $(80.95)$ & \\
College of Engineering & 9 & 11 & 9 \\
$\mathrm{~N}=20$ & $(45.00)$ & $(55.00)$ & \\
University-wide & 17 & 56 & 23 \\
$\mathrm{~N}=73$ & $(23.28)$ & $(76.71)$ & \\
\hline
\end{tabular}

\section{University Council Reforms}

The University Council recommendations were widely reported and discussed in the Japanese media, but have received limited international coverage. The best source of information about the 1998 reforms is the report itself, and the various articles in Japanese newspapers that have documented the public's reaction to the recommendations and the progress being made by educators to implement the reforms. An ethnography of the documents and media accounts that pertain to the 1998 reforms are presented in this section in order to provide a background for the analysis that follows. 
In the preface of the two-chapter report entitled "A Vision for Universities in the $21^{\text {st }}$ Century and Reform Measures to be Distinctive Universities in a Competitive Environment," the University Council urges higher education institutions in Japan to continue structural reforms in response to the National Council on Educational Reform (NCER) recommendations. In the first chapter of the report, the University Council discusses the necessity of "diversification and individualization of higher educational institutions" with more specific objectives for reform detailed in the second chapter. In order to achieve the goals and objectives outlined in the report, the Council proposes that colleges and universities implement "comprehensive and practical reform measures" in accordance with the following four basic philosophies:

- qualitative enhancement of education and research with the aim of cultivating students' ability to pursue one's own ends.

- more flexible education and research systems to secure universities' autonomy.

- improvement of the administrative structure to facilitate responsible decision-making and implementation, that supports the philosophy.

- individualization of universities and continuous improvement of education and research by establishing a plural evaluation system.

The 1998 University Council recommendations would be used as a blueprint for the Ministry of Education to draft bills for revising the related laws. An article in the November 2, 1998 issue of The Nikkei Weekly ("Panel Urges Reform," 1998) described the University Council's report as the most 
comprehensive reform of higher education since the university chartering standards were revised in 1991. According to the article, the University Council, through its reform, sought to improve the quality of education and research by adding more flexibility to the higher education system and raising the standards of student achievement. The reform also sought to strengthen decision-making at the university-level while also making the faculty and administration more accountable to the public.

Reforms to Improve the Quality of Education and Research. Many of the University Council's recommendations, such as flexible academic schedules and transfer of credits between universities, were strikingly similar to elements already incorporated into the higher education system of the United States. In fact, a July 8, 1998 editorial in The Japan Times ("Japan's Universities," 1998) commented on the irony that half a century after the American Occupationinstituted reforms, Japan's own education experts would be calling for its universities to become more like their counterparts in the United States.

The majority of universities appeared to welcome the reforms, especially those reforms that were intended to add flexibility to the curriculum. According to a poll of university presidents taken by the Kyodo News Service, ("60\% of Universities," 1998), 60\% of the Japanese universities offering four-year courses were willing to consider adopting a system that would allow students with high grades to graduate within three years. Seventy percent of the universities reported that they were studying the feasibility of a one-year master's degree program to attract working people to graduate school. 
The Asahi Shimbun praised the report in its October 27, 1998 editorial ("University Entrance," 1998), commenting that the report went further than previous reform efforts to raise the standards of university education in Japan. However, the editorial also appeared critical of the report because it failed to adequately address the entrance examination system. Public universities and most private universities still rely primarily on standardized exams to select students, which has produced the infamous ritual of juken jigoku, or entrance exam hell, where students must endure the tremendous pressure of preparing for these exams. The "entrance exam hell" has long been deemed a major cause of Japan's various educational problems. All public universities and most private universities use the Ministry of Education administered exams offered each January to select students for their own exams that usually take place in February and March. Because the majority of students are unable to obtain the necessary test score to enter the school of their choice, many of these students will delay their university education for one year to attend "cram schools" to prepare for the next year's exams.

Soon after making its 1998 reform recommendations, the University Council turned the issue of the university entrance exam system over to the Education Minister's Central Council for Education. In November 1998, Minister of Education Akito Arima requested his advisory panel to study ways to reform the university entrance system, including changes to the standardized admission examinations. The Central Council was directed to report within one year, and the recommended changes would begin no later than 2005 ("Education 
Reforms," November 7, 1998). In November 1999, the Central Council recommended that Japan's universities should allow students to choose the institution they want to enter based on their individual plans for the future, rather than on their percentile scores ("Panel Urges," Nov. 1, 1999). The Central Council made its final recommendations for reforming the entrance exam system in January 2000, including proposals to introduce face-to-face interviews and reduced emphasis on percentile test scores. The proposals were met with severe opposition from the Japan Association of National Universities that countered that the proposals would be too costly and time-consuming to implement ("Universities RIP," 2000). The rejection of the proposals by the Association reflected the general displeasure that national universities have had with the University Council reforms.

Reforms to Strengthen Decision-Making. The call by the University Council for greater autonomy of the university and stronger decision-making power for the university's administration was perhaps the most controversial item in the Council's report as reflected in the amount of coverage this aspect of the reform received in the Japanese media. Implementation of the University Council's recommendations for greater autonomy for national and public universities was not expected to occur for many years. According to a September 20, 1999 article in the Nihon Keizai Shimbun ("Ministry Agrees," 1999), the government's decision to change the status of national universities was originally not expected until fiscal year 2003. Surprising many in the Japanese academic world, the changes began much sooner than anyone could 
have imagined. In September 1999, the Ministry of Education announced its plans to convert the 99 national universities into independent agencies with autonomous governing over their organization, budgets, and staff assignments, including selection of the university president and control over faculty appointments ("Ministry Agrees," 1999). Less than six months later, the Cabinet approved a bill to create a third-party system to objectively evaluate the 99 national universities ("Government Plans," 2000). The bill, sent to the Diet (equivalent to the Congress and Senate in the United States) for final approval, revised a law pertaining to the establishment of national schools. Not surprisingly, these unexpected moves by the Japanese government resulted in both criticism and opposition.

A September 20, 1999 editorial in the Asahi Shimbun ("Putting Some," 1999) criticized the government's motivation for making the decision, asserting that it lacked a desire for genuine reform. The primary reason for moving so quickly, according to the editorial, was to respond to the public's criticism against the national universities remaining unaffected by a government plan to cut the number of its employees by $25 \%$ by fiscal 2010 . "What is worrisome," says the editorial, "is that the government and the Liberal Democratic Party which are pushing for university independence seem to have an ulterior motive: cutting the educational budget." According to others, however, the changes have not moved quickly enough. An editorial in the September 20, 1999 issue of Nihon Keizai Shimbun ("National Universities," 1999) welcomed the government's decision to reorganize the national universities into independent corporate entities, but 
argued that the conversion of national universities into independent agencies would only have meaning if it leads to privatization. "National universities," said the editorial, " have been looked up to for a long time, but it appears their mission is at an end. In this era of private-sector leadership, special universities aimed at cultivating bureaucrats are no longer needed."

Opposition to the government's decision to convert the national universities into independent agencies was perhaps greatest among the faculty members of the national universities. An article in the February 10, 2000 issue of Asahi Shimbun ("Universities No Longer," 2000) reported one Tokyo University faculty member as saying that certain academic programs may lose government funding priority once they are exposed to competition from other areas under the new system. On the other hand, some segments of the national university community reacted more positively to the government's decision, such as the five national universities that started talks on forming a consortium to offer a common general educational curriculum and accept student transfers to enhance their competitiveness and cost-effectiveness ("Top Universities," 1999).

\section{Reforms to Increase Accountability of the Faculty and}

Administration. The University Council's final recommendation was that universities become more accountable to the public by setting up self-evaluation systems, both internal and external, and publicizing these assessments. The Council also recommended that the third-party evaluations should strive for objectivity and that they be used to help determine how much funding public universities receive from the government. This part of the reform has been 
greeted with some skepticism from the Japanese media. For example, the author of a July 8, 1998 editorial in The Japan Times ("Japan's Universities," 1998) predicted that the self-evaluation systems would be difficult to implement given the bureaucratic tendency of the Japanese government to promote the status quo. An October 27, 1998 editorial in The Yomiuri Shimbun ("Universities Need," 1998) praised the University Council for its recommendations to set up a third-party evaluation system, but predicted that universities would resist this part of the reform. According to the editorial, at the time of the report, nearly 90 percent of the country's universities, including private universities, were said to have introduced a self-assessment system; however, the results were rarely made public, and when they were, the objectivity of the results was questionable.

\section{Academic Governance Process at Toshi University}

At Toshi University, the President, who is also the Chairman of the Board of Trustees, holds the ultimate decision-making authority over the curriculum, teaching and research. As shown in the diagram (Figure 3), the Board of Trustees is the final decision-making body with regard to academic affairs, but the majority of the governance activities are carried out by the President, the Academy Council, the Deans' Council and the Faculty Councils. The Deans'

Council is the most important academic decision-making body at Toshi University after the President and the Board of Trustees.

Deans' Council. According to the Toshi University Constitution, the Dean's Council is the supreme consultant committee on issues related to 
Figure 3

\section{DECISION-MAKING AND ADVISORY BODIES FOR ACADEMIC GOVERNANCE AT TOSHI UNIVERSITY}

DECISION-MAKING BODIES

ADVISORY BODIES

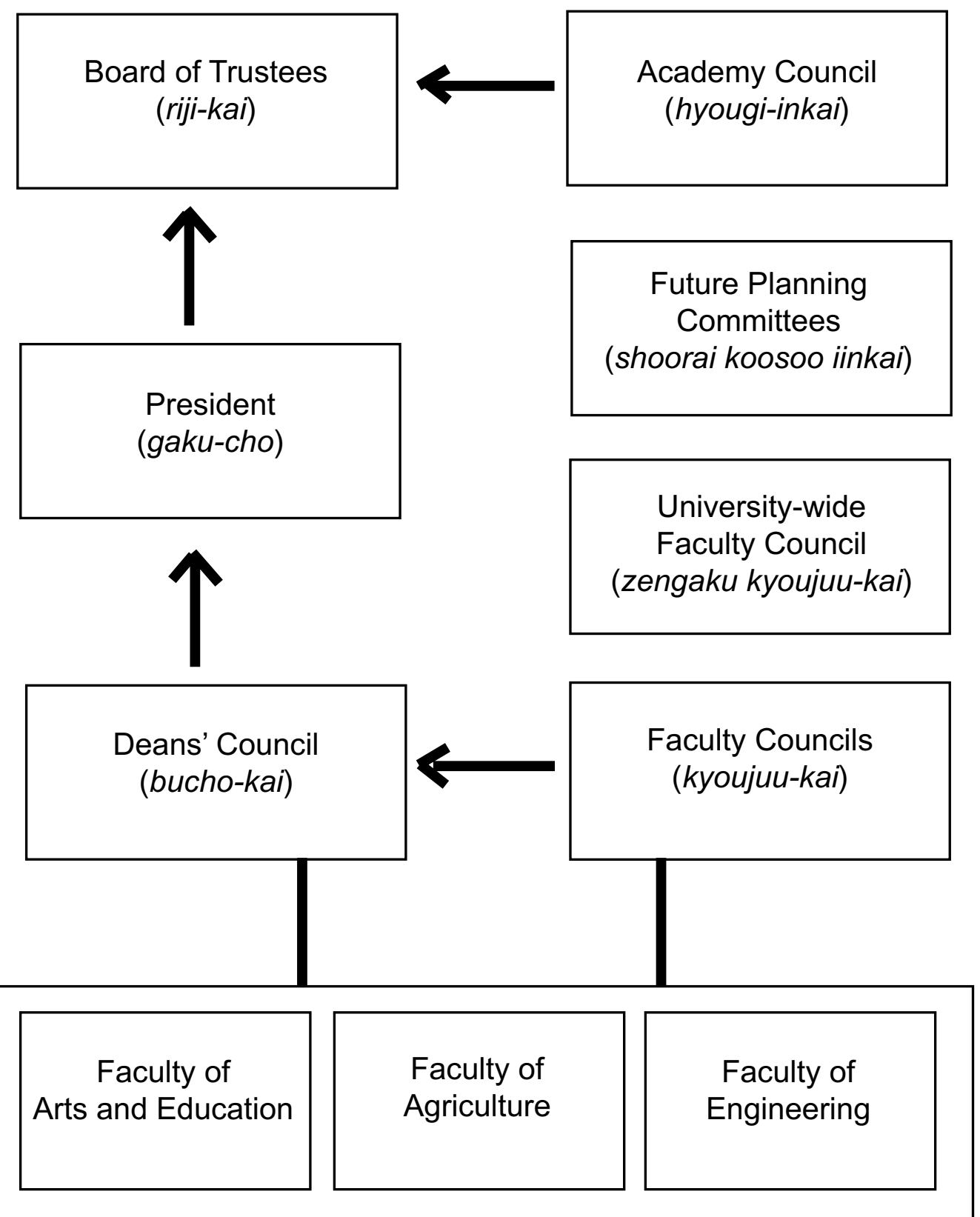


teaching and research. The President of the University calls the meetings of the Dean's Council to discuss the following:

(a) fundamental administrative policies regarding teaching and research and personnel; (b) issues related to discussions conducted in the Faculty Councils; (c) issues related to discussion conducted in the various organizational meetings; (d) issues related to the establishment, abolishment and revision of school regulations; (e) issues and inquiries submitted by the President; and (f) other issues that are significant to the administration and management of the University. (Toshi University Constitution)

The Deans' Council is a kind of coordinating agency for the interests of the respective faculties and research institutes. Each college and department has a Faculty Council (kyojyu-kai) where academic-related matters are discussed; however, the ultimate authority over academic affairs resides with the Dean. The Dean gathers reports from the Faculty Council meetings and coordinates the vested interests of his faculty and chairs at the Deans' Council meetings .

The Deans' Council is more concerned with the larger issues and policies related to academic programs and faculty affairs. It would not, for example, be concerned with the selection and evaluation of individual faculty members. On the other hand, the deans do play an important role in personnel matters related to selecting and evaluating faculty. According to the Director of the Office of Personnel at Toshi University, upon the vacancy of a full-time teaching position, the Dean will develop a plan for how to respond to the vacancy and will present 
this plan to the President and Board of Trustees members. The plan will be based on the recommendations made at the Faculty Council meetings, and it may include a list of prospective candidates for the vacant position. If it is decided that the vacancy should be filled, the Dean will recommend a select group of candidates to be interviewed by the President and Board of Trustees members. The final decision to employ the faculty member will be made, not by the Deans' Council, but by the President and the Board of Trustees members, in that order.

According to the various interviews with faculty and administrators at Toshi University, only deans and directors serve on the Deans' Council, known as Bucho-kai in Japanese. The translation of Bucho as "dean" is a loose one and is also used to refer to the director of an academic or administrative division. The term is also used regularly in the business world to refer to upper-level managers. In Japanese, cho means head or chief of a division or section (opposed to a department or office). Kai means meeting; therefore, Bucho-kai can be directly translated as a meeting of all the chiefs. Administrators, curriculum coordinators and department chairs report directly to the Bucho -- the deans and directors. The department chairs have decision-making authority over their department and rank higher than administrators or curriculum coordinators with regard to their importance as academic decision-makers.

One faculty member commented that there was some confusion among some of the faculty and staff about how members of the Deans' Council are selected. According to this faculty member, the Deans' Council is supposed to 
include all of the deans and directors; however, some directors do not participate in the Council meetings, and the reason was unclear. The majority of faculty members, even many of the most senior faculty members, have never attended a Deans' Council meeting and the agenda and minutes are not made public. Apparently, many faculty do not possess a clear understanding of how the Deans' Council meetings function to coordinate the interests of the faculty and promulgate decisions as these meetings are intended.

\section{Ethnographic Perceptions of a Deans' Council Meeting. The} researcher had the unique opportunity to attend a Deans' Council meeting at Toshi University during the site visit. Unlike the structured interviews, the faculty survey, or the collection and evaluation of the documents, the Deans' Council meeting provided the researcher with an opportunity to participate as well as observe activities directly. In this way, the researcher was able to get the feel of what a Deans' Council meeting was actually like, as opposed to just being told by an interviewee what occurs at such an event. The following account of a Deans' Council meeting was based on the perceptions of the researcher:

Like the child who finally gets to join a meeting in his big brother's secret club, I ventured into my first Deans' Council meeting. The airconditioned room was refreshing on a hot and humid afternoon. One big window planked that back of the room with a view of a garden made lush and green by the rainy season. The large room was empty of people and appeared even more open and spacious due to its sparse furnishing. There was only one large conference table in the middle of the room. 
The table was large enough to seat over 30 people, and I wondered how many deans would actually attend the meeting. I had met about ten deans, but I was not sure how many deans there were at Toshi University in total. I would soon find out. The President's executive assistant, a man in his 60's who had worked at Toshi University for over 30 years, guided me to a small desk and chair at the back of the room that had been arranged especially for my visit. I was told that the meeting would begin in about ten minutes and the assistant left me in the room alone to anticipate what would happen next.

During the wait, I reviewed what I did know about the Deans' Council meetings, which was not much because few of the interviewees had talked in detail about what occurs at these meetings. In fact, few of the faculty members I talked to had ever attended a meeting, or for that matter, entered the conference room where the meetings take place. One faculty member who has taught at Toshi University for over twenty years commented that he had never entered the building in which the Deans' Council meetings are held once per month. His comments conjured up images of a forbidden temple inside of which are practiced mysterious rites and ritual. In fact, throughout my interviews with the various administrators and faculty, when the discussion shifted to the Deans' Council meetings, the interviewees' non-verbal communication and spoken language would invariably become more reverent. I quickly became aware that there was something sacred about these meetings. 
They were considered important, not just for practical purposes, but also for ceremonial ones. Moreover, due to the exclusivity of these meetings, which are only attended by the most privileged members of the group, the meetings have an aura of mystery about them as perceived by most of the faculty and staff at Toshi University.

Having previously lived in Japan for about four years, I was quite sensitive to the distinction that Japanese make between uchi, literally the "house," which implies the "group," and soto, literally the "outside." The Japanese are very careful about whom they let into their group. As a foreigner in Japan, or gaijin, who was not a member of Toshi University, I was well aware of my status as an outsider and thus the President's invitation to attend a Deans' Council meeting was a great honor. It meant that I had developed the trust necessary to be a part of the group, albeit for a very short period of time and set apart from the main table. Actually, I had asked several deans during my interviews if they thought I could attend a Deans' Council meeting during my site visit, and they all replied that it would be impossible. I was told that an "outsider," meaning anyone who is not a dean at Toshi University, has never been allowed to attend a Deans' Council meeting at Toshi University, and that this was the standard protocol at any university in Japan. After learning the date and time of the next Deans' Council meeting, I went directly to the President and requested to attend the meeting. To my surprise, the next day, I learned that my request had been approved. 
As the members of the Deans' Council began to enter the room one by one, I began to feel increasingly conspicuous. It was apparent from their surprised gestures that they were not aware that an "outsider" would be attending the meeting. The deans did not stand around the table and chat as one might expect at a meeting in the United States, instead, they promptly and quietly took seats around the table. The deans were all dressed conservatively, wearing dark suits and white shirts, as is the custom at most corporations and universities in Japan. The last person to enter the room was the President whose chair was located at the head of the conference table nearest the entrance where his back would be facing the door. This was surprising to me. Usually during a meeting at a Japanese company or university, the leader of a group will sit furthest from the entrance and facing the door. I wondered if this seating arrangement by the President was intentional, perhaps to make his subordinates feel less pressured by his authority and to encourage more collegial participation at the meeting. Moreover, the deans did not stand when the President entered the room and bow, as I had expected. I suspect that at one time this was the custom, but the President is not very comfortable with formality and he probably ended the practice long ago.

In total, there were 31 individuals seated at the table, all were men, most were directors of administrative divisions. In addition to the deans and directors, there were also two full-time members of the Board of Trustees seated next to the President: to the President's left was seated 
the Trustee member who oversees the university administration and next to him the Director of the Office of Personnel; and to the President's right was seated the Trustee member who oversees the academic affairs of the University and next to him the Dean of the College of Arts and Education. In Japan, seating is important and people usually sit according to rank. The physical proximity of the above four individuals to the President at the meeting was an implicit statement of their power at Toshi University, which was either equal to or greater than their position of authority.

Before the meeting commenced, the President stood behind his chair as the deans settled into their positions around the table. The President spoke first and he immediately recognized me as a visitor who was conducting research at his university. He asked me to introduce myself to the group. After my introduction, the President took his seat and the meeting began. Interestingly, after I finished my introduction (which was, by the way, conducted in Japanese) the President remarked that my Japanese language ability was limited and that I would not understand the discussion completely. This comment appeared to be intended to comfort some of the members at the meeting who may not have been convinced that my presence was a good thing.

During the hour and a half meeting, the deans and directors took turns speaking on issues related to their individual departments. Discussion and debate were limited. There appeared to be a carefully planned agenda of issues related to the administration of the University. 
The President remained the authority throughout the meeting, both as the responsible person and the "go-between." About half of the members presented, usually for five or ten minutes with little or no discussion. Each presentation was usually followed by some comments from the President who presided over the meeting as a facilitator, neither showing approval or disapproval, but steering the meeting like the chairman of a committee.

As for the topics that were discussed in the meeting, few were controversial in nature. For example, the topic that consumed the most discussion time was related to the coordination of an upcoming school festival. The way in which these topics were discussed was actually more interesting to me than the topics themselves, at least from the perspective of gaining a deeper understanding of the culture. For example, during the meeting, the deans chose the more humble forms of the language (i.e. subordination of self to others) to discuss their own college or division. This was not surprising as Japanese usually think first of being part of the group. In their presentations, "We" would always come before "I." The deans would usually begin their presentation with "We" of this college or "We" of this division, rather than saying, "I think," as we would do in the United States. Humbleness is actually a major feature of the Japanese language and is used when one talks about self and their group.

Another major feature of the Japanese language is politeness, which is used when one's language is directed at others. There are multiple gradations of language to express politeness in Japanese. Levels 
of politeness are used to fit each occasion, depending on the relative age, status, role, gender, and familiarity of the speakers. For example, polite language was frequently used when the deans referred to another member at the meeting. On the other hand, the President was much less formal in his use of the language, although never disrespectful to another member. The President's informality was probably intentional and meant to put the other members at ease and to encourage openness and frankness.

By the end of the meeting, I as was unable to determine whether or not agreement had emerged on any of the issues that had been discussed. There had been no decisions made and no votes taken. My impression was that the Deans' Council meetings served more as a forum for presenting ideas and discussing issues, and, even more importantly, working toward a consensus. Throughout the meeting, I sensed that the President was listening intently and carefully to each presentation. He appeared interested and observant. My impression was that he was as much interested in the mood of the discussion, as the actual content of the presentations. The President of Toshi University is a proactive leader and he is not afraid to make decisions. However, he also knows that his decisions cannot be successfully implemented without wide support. For this reason, the President must be sensitive to the mood of the discussion. If the mood is such that no consensus seems possible, then it may be best to defer making a decision. On the other hand, if he determines that the 
mood of the deans is primarily positive, the opportunity for making the decision is probably near.

Academy Council. Unlike the Board of Trustees or the Deans' Council, the Academy Council is not a decision-making body, and it does not have either voting or veto power over the Board of Trustees. Instead, it serves more as an advisory body, or as a check on the Board of Trustees. The Academy Council also selects the new Board of Trustees members after the current members' term expires or they retire. The Academy Council is described in the Toshi University Constitution, and it is a common feature of all private schools in Japan and justified under the Private School Law of Japan. The Academy Council is composed of 15 members with representation from the Toshi K-12 schools, Junior College for Women and Toshi University. According to the Toshi University Constitution, Council members are elected by the Board of Trustees and the Council must be primarily composed of elected faculty members and alumni of one of the schools at Toshi Academy. Council members hold five-year office terms, but can be elected to serve for more than one term.

Future Planning Committee. Another university-wide committee that usually deals with issues that affect the university at-large and tends to serve as an advisory body is the Future Planning Committee (shoorai koosoo iinkai). The Future Planning Committee meetings are not mentioned in the Toshi University Constitution, but they have evolved as a traditional decision-making model at Toshi University. Each year during August, various departments or colleges will form committees to discuss their concerns and ideas for change. A report is 
generated from the meetings, and the information is shared within the University. For example, a committee might be organized to discuss distance learning and how it should be implemented. According to the President of Toshi University, these committees are a source for new ideas and new proposals for change; however, actual implementation is another matter:

Every school, division and department has ideas for changes they would like to make, but they do not all get initiated equally. Much depends on my personal relationship with the dean. If I can speak frankly with the dean, instead of on a formal level, there is more likelihood that the proposals will be initiated. If my relationship with the dean is on a formal level as a supervisor-employee relationship, rather than a familiar relationship, there is not much chance of changes being implemented unless it's a government mandate of some kind. (President of Toshi University, Personal Communication, June 1999)

Faculty Council. All full-time faculty members at Toshi University belong to one of around a dozen Faculty Councils located in their respective department or college. Faculty Councils are usually not university-wide committees, but meetings of the faculty of a particular department or college. All full professors, associate professors, lecturers and other faculty and staff participate in these meetings. The chair of a department or dean of a college calls the Faculty Council meetings on a regular basis and the President may also call these meetings if he perceives it as necessary. According to the Toshi University 
Constitution, the main issues under discussion in the Faculty Councils are the curriculum, research and other academic-related matters:

... student admission, change of major, transfer, studying abroad, readmission, dropout, graduation and exams; reward and punishment; school regulation; and items submitted by the President and other necessary issues. (Toshi University Constitution)

Also, once per year, the President calls upon all faculty members to have a meeting. This meeting is referred to as the University-wide Faculty Council (zengaku kyoujuu-kal) and consists of all the full professors in all of the departments. Associate professors, lecturers, assistants, and staff are also welcome to attend these meetings. Issues recognized by the President as important are discussed at the University-wide Faculty Council and if the President perceives the need for it, he may organize the faculty into smaller groups where each group addresses specialized areas of concern.

\section{Faculty Reactions to the 1998 University Council Reforms and their Impact}

\section{on Academic and Faculty Affairs at Toshi University}

The results of the survey reveal some opposition to the 1998 University Council reforms at Toshi University, although not to the same degree found in some of the national and public universities. The aim of the 1998 University Council report was to upgrade Japan's higher education to be in line with the other leading higher education systems in the world. The report contains numerous recommendations that the University Council hoped would lead to the establishment of tougher standards for students and educators alike, while also 
adding flexibility and incentive to the system. Some of these recommendations have already been recently adopted at Toshi University. The following list contains the main elements of the reform that pertain to academic programs and faculty affairs, many of which were addressed in the survey questionnaire:

- Universities should be allowed to grant bachelor's degrees to those with less than four years of attendance at universities.

- More emphasis should be aimed at developing the professional skills of those already in the workforce, especially in Master's degree programs.

- Universities should increase the number of credits they will allow students to transfer.

- Universities should specify criteria for assessing student achievement and implementing a more rigorous grading method.

- Faculty research should be more sensitive to community and business needs.

- Faculty should be required to participate in the self-evaluation of the University.

- Faculty should be required to prepare and distribute syllabi for the classes they teach.

- Students should evaluate their instructors and the classes they take.

- Less emphasis should be placed on final examinations and more on written assignments and attendance when grading students.

- Universities should be more flexible about admitting students in the fall.

- Universities should limit the number of credits undergraduates can earn each year. 
The data reported in Table 20 suggest that faculty at Toshi University tended to agree with all of the above changes pending in the reform except for the recommendation that universities should limit the number of credits undergraduates can earn each year. While the intention of the University Council in making this recommendation was to establish tougher standards for students, $49 \%$ of the faculty at Toshi University opposed this reform item and only about $28 \%$ agreed with the reform proposal. The University Council hoped that by limiting the number of course credits a student can seek in a school year, the practice of students amassing all their required credits in the first three years to free their senior year for job-hunting would be eliminated. Some also disagreed with at least four other reforms. About $28 \%$ of the faculty respondents reported that they did not agree that the university should be more flexible about admitting students in the fall. Over $18 \%$ of the respondents indicated that they did not agree with the reform that would allow faculty evaluation by their students, and the same percentage reported that they disagreed with the recommendations that faculty should utilize alternative methods of grading. The next largest pocket of disagreement was related to the recommendation that faculty should prepare and distribute syllabi in their classrooms. This reform was unpopular with about $15 \%$ of the faculty respondents. Of the four reform items with which faculty respondents tended to indicate the most disagreement, three had already been implemented at Toshi University by the time the survey was distributed. 
Table 20

All Faculty Respondents' Opinions about the Changes Pending in the Reforms that could Affect their Teaching or Research

\begin{tabular}{|c|c|c|c|c|}
\hline$\overline{C h}$ & $\begin{array}{l}\text { Mostly } \\
\text { Agree }\end{array}$ & $\begin{array}{c}\text { Mostly } \\
\text { Disagree }\end{array}$ & $\begin{array}{c}\text { No } \\
\text { Opinion }\end{array}$ & $\mathrm{N} / \mathrm{A}$ \\
\hline $\begin{array}{l}\text { Collaborative research among faculty } \\
\text { members of different departments should be } \\
\text { encouraged. } \mathrm{N}=87\end{array}$ & $\begin{array}{c}71 \\
(81.60)\end{array}$ & $\begin{array}{c}3 \\
(03.44)\end{array}$ & $\begin{array}{c}13 \\
(14.94)\end{array}$ & 9 \\
\hline $\begin{array}{l}\text { Interdisciplinary courses taught by faculty of } \\
\text { different departments should be encouraged. } \\
\mathrm{N}=85\end{array}$ & $\begin{array}{c}51 \\
(60.00)\end{array}$ & $\begin{array}{c}7 \\
(08.23)\end{array}$ & $\begin{array}{c}27 \\
(31.76)\end{array}$ & 11 \\
\hline $\begin{array}{l}\text { Faculty research should be more sensitive to } \\
\text { community and business needs. } \mathrm{N}=85\end{array}$ & $\begin{array}{c}62 \\
(72.94)\end{array}$ & $\begin{array}{c}6 \\
(07.05)\end{array}$ & $\begin{array}{c}17 \\
(20.00)\end{array}$ & 11 \\
\hline $\begin{array}{l}\text { Faculty should be required to participate in } \\
\text { the self-evaluation of the University. } N=84\end{array}$ & $\begin{array}{c}56 \\
(66.66)\end{array}$ & $\begin{array}{c}7 \\
(08.33)\end{array}$ & $\begin{array}{c}21 \\
(25.00)\end{array}$ & 12 \\
\hline $\begin{array}{l}\text { Faculty should be required to prepare and } \\
\text { distribute syllabi for the classes they teach. } \\
\mathrm{N}=89\end{array}$ & $\begin{array}{c}69 \\
(77.52)\end{array}$ & $\begin{array}{c}13 \\
(14.60)\end{array}$ & $\begin{array}{c}7 \\
(07.86)\end{array}$ & 7 \\
\hline $\begin{array}{l}\text { Students should evaluate their instructors and } \\
\text { the classes they take. } \mathrm{N}=86\end{array}$ & $\begin{array}{c}61 \\
(70.93)\end{array}$ & $\begin{array}{c}16 \\
(18.60)\end{array}$ & $\begin{array}{c}9 \\
(10.46)\end{array}$ & 10 \\
\hline $\begin{array}{l}\text { Less emphasis should be placed on final } \\
\text { examinations and more on written } \\
\text { assignments and attendance when grading } \\
\text { students. } \mathrm{N}=85\end{array}$ & $\begin{array}{c}44 \\
(51.76)\end{array}$ & $\begin{array}{c}16 \\
(18.82)\end{array}$ & $\begin{array}{c}25 \\
(29.41)\end{array}$ & 11 \\
\hline $\begin{array}{l}\text { The University should be more flexible about } \\
\text { admitting students in the fall. } \mathrm{N}=86\end{array}$ & $\begin{array}{c}48 \\
(55.81)\end{array}$ & $\begin{array}{c}24 \\
(27.90)\end{array}$ & $\begin{array}{c}14 \\
(16.27)\end{array}$ & 10 \\
\hline $\begin{array}{l}\text { The University should limit the number of } \\
\text { credits undergraduates can earn each year. } \\
\mathrm{N}=87\end{array}$ & $\begin{array}{c}24 \\
(27.58)\end{array}$ & $\begin{array}{c}43 \\
(49.42)\end{array}$ & $\begin{array}{c}20 \\
(22.98)\end{array}$ & 9 \\
\hline
\end{tabular}




\section{Faculty Perceptions about the 1998 University Council Reforms and their}

Implications for Academic Governance at Toshi University

Several elements of the 1998 University Council reforms pertain directly to the process of academic governance. One of these recommendations is that the president should set the objectives and make plans for education and research for the university at large. Unlike most public universities and many other private universities, Toshi University already has a president who plays a central role in the academic governance of his university, so this reform recommendation does not appear to apply to Toshi University. According to the survey (Table 21), the majority of respondents agreed that the president should play the central role in the academic governance, although about $21 \%$ disagreed. No comments were given on this part of the survey, so the type of academic governance system the faculty who disagreed would prefer is unknown.

The 1998 reforms also recommend that universities specify the basic functions of a senate and a faculty council respectively, but does not go so far as to recommend that all universities should have a faculty senate. However, in those cases where a university does have a faculty senate, the reform recommends that the presidents and deans should make the final decisions. A university-wide faculty decision-making body does not exist at Toshi University. Although Toshi University has a Faculty Council that represents each of its departments and colleges, the faculty members do not meet as a faculty senate on a university-wide level and make decisions about academic programs, instruction and research. The faculty senate is not a common feature of private 
Table 21

All Faculty Respondents Indicate their Opinions about Proposals for Reforming the Existing University System Japan as Recommended Recently by the University Council

\begin{tabular}{|c|c|c|c|c|}
\hline Proposals & $\begin{array}{l}\text { Mostly } \\
\text { Agree }\end{array}$ & $\begin{array}{c}\text { Mostly } \\
\text { Disagree }\end{array}$ & $\begin{array}{c}\text { No } \\
\text { Opinion }\end{array}$ & $\begin{array}{c}\text { No } \\
\text { Answer }\end{array}$ \\
\hline $\begin{array}{l}\text { The president should play the } \\
\text { central role in efforts to set } \\
\text { objectives and make plans for } \\
\text { education and research of } \\
\text { university at large. } \mathrm{N}=86\end{array}$ & $\begin{array}{c}52 \\
(60.46)\end{array}$ & $\begin{array}{c}18 \\
(20.93)\end{array}$ & $\begin{array}{c}16 \\
(18.60)\end{array}$ & 10 \\
\hline $\begin{array}{l}\text { The faculty senate should be } \\
\text { responsible for making decisions } \\
\text { about academic programs, } \\
\text { instruction and research, but the } \\
\text { presidents and deans should } \\
\text { make the final decisions. } \mathrm{N}=85\end{array}$ & $\begin{array}{c}47 \\
(55.29)\end{array}$ & $\begin{array}{c}22 \\
(25.88)\end{array}$ & $\begin{array}{c}16 \\
(18.82)\end{array}$ & 11 \\
\hline $\begin{array}{l}\text { The president should give } \\
\text { direction when the policy and } \\
\text { standard of personnel affairs, } \\
\text { including faculty appointments, } \\
\text { are decided. } \mathrm{N}=83\end{array}$ & $\begin{array}{c}49 \\
(59.03)\end{array}$ & $\begin{array}{c}10 \\
(12.04)\end{array}$ & $\begin{array}{c}24 \\
(28.91)\end{array}$ & 13 \\
\hline
\end{tabular}

universities in Japan, although it is a common feature of public and national universities. In fact, at some public universities, the faculty senate is even more powerful than the president. Faculty members at Toshi University were asked on the survey if they thought a faculty senate should be responsible for making decisions about academic programs, instruction and research. About 55\% of the respondents agreed that Toshi University should have a faculty senate with 
limited decision-making authority over academic affairs. This item also received the highest rate of disapproval with approximately $26 \%$ of the respondents indicating that they disagreed with this proposal.

Another University Council reform that relates to academic governance is the recommendation that the president should give direction with regard to policies and standards of personnel affairs, including deciding faculty appointments. The University Council also recommends that the selection process of personnel should be made more objective and transparent by advertising positions and improving the structure of selection committees. These reforms have direct implications for most public and national universities where faculty appointments are decided by the Ministry of Education. They also have implications for many private universities where the faculty senate decides matters of personnel. However, these reforms do not have implications for Toshi University. This system is currently the one at Toshi University, in which the President and the Board of Trustees make the final decision on all faculty appointments. According to the Director of Personnel at Toshi University, the deans and directors, as well as the Faculty Council, are also usually involved in the process of selecting faculty. The majority of the faculty members at Toshi University appear to be satisfied with the system of presidential authority over personnel decisions with $59 \%$ of the respondents indicating approval and only $12 \%$ indicating disapproval.

Many of the reforms that the University Council has recommended for improving the governance system are already in place at Toshi University, 
including the strong decision-making model with the president at the center of power. The Ministry of Education hopes that by relaxing its control over the public and private universities that the individual university decision-making systems will be strengthened. According to the survey results (Table 22), only $11 \%$ of the faculty at Toshi University agree that the Ministry of Education should have more power and that less power should be allotted to the university. Most faculty either agree that the Ministry of Education should have less power (52\% hold this opinion) or they do not have an opinion on the issue, with about $37 \%$ giving the latter response to the survey question.

\section{Table 22}

Faculty Respondents' Agree or Disagree that the Ministry of Education should have Less Power and that More Power should be Allotted to the University's Faculty and Administration as a Way to Strengthen Decisionmaking

\begin{tabular}{lcccc}
\hline & $\begin{array}{c}\text { Mostly } \\
\text { Agree }\end{array}$ & $\begin{array}{c}\text { Mostly } \\
\text { Disagree }\end{array}$ & $\begin{array}{c}\text { No } \\
\text { Opinion }\end{array}$ & $\begin{array}{c}\text { No } \\
\text { Answer }\end{array}$ \\
\hline Arts and Education & 20 & 4 & 13 & 6 \\
$\mathrm{~N}=37$ & $(54.05)$ & $(10.81)$ & $(35.13)$ & \\
Agriculture & 4 & 5 & 14 & 1 \\
$\mathrm{~N}=23$ & $(17.39)$ & $(21.73)$ & $(60.86)$ & \\
Engineering & 21 & 1 & 5 & 2 \\
$\mathrm{~N}=27$ & $(77.77)$ & $(03.70)$ & $(18.51)$ & \\
University-wide & 45 & 10 & 32 & 9 \\
$\mathrm{~N}=87$ & $(51.72)$ & $(11.49)$ & $(36.78)$ & \\
\hline
\end{tabular}




\section{Administrative Governance Process at Toshi University}

Unlike public universities in Japan, the key decision-making organs over financial affairs and other managerial activities at private universities are not the faculty and deans, but the Board of Trustees. In the case of Toshi University, the President is a key decision-maker over the financial and administrative affairs of the school due to his dual role as the Chairman of the Board of Trustees. The Ministry of Education through its regulations also plays an important role in the administrative governance process. In addition, several administrative offices at Toshi University are involved in the financial management of the institution, which provide support to the President and Board of Trustees and have limited decision-making power. These offices are situated within the Division of Operations and Management and include the Office of Institutional Research, the Office of Secretariat, the Office of Campus Affairs, the Office of Personnel, the Office of Bursar, and the Office of Property and Maintenance. Faculty members at private universities rarely make decisions related to the financial affairs of the institution, unless they are serving as members of the Board of Trustees. The survey results show that the faculty members at Toshi University have limited participation in the financial decision-making process, as well as limited knowledge of the functions of the Board of Trustees.

As a school corporation, Toshi Academy is incorporated under the guidelines set forth in the Private School Corporation Law of 1949. This law gives the Board of Trustees ultimate authority over the corporation. While most private universities in Japan are doing non-profit work, they are treated by the 
Japanese government as for-profit corporations. For example, private universities in Japan must pay corporate tax (on their "profit" making activities) at the same rate as businesses and there is no tax deduction for those contributing to school corporations. As a result, many private institutions, including Toshi University, develop commercial enterprises, such as managing hotels and renting buildings in order to supplement their income from tuition and fees that may account for up to $70 \%$ of the school's income.

Board of Trustees. The Board of Trustees, or riji-kai as it is known in Japanese, consists of seven trustees, one of whom serves as Chairman of the Board of Trustees (riji-cho). Three members of the Board of Trustees are parttime trustees (joumu-rij), and four are full-time trustees (jounin-riji). The full-time trustees are full-time, senior faculty members of Toshi University or Toshi Academy and they are physically present on the campus every day, fully engaged in their various duties as members of the Board of Trustees. The parttime trustees, on the other hand, might only visit the campus once or twice per year, and their role is more ceremonial. The part-time trustees are usually influential members of the business or political community. The core decisionmakers at Toshi University are the full-time trustees whose supreme authority over all administrative and academic affairs is justified in the Constitution to provide for a more efficient administration and operation of the corporation. According to the Constitution, the part-time trustees assist the other full-time trustees and can serve as substitutes if needed. At Toshi University, each one of the trustees has been delegated by the Chairman to oversee a different area of 
the decision-making: one of the trustees oversees the administrative affairs of Toshi Academy, another oversees the academic affairs of Toshi University and Toshi Junior College for Women, and another oversees the academic affairs of Toshi K-12 Schools. The constitution and by-laws of Toshi University require that trustees hold five-year office terms, but they can be elected to serve for more than one term. Both the full-time and part-time trustees are chosen by the President and the Academy Council. The trustees hold official meetings twice per month, but actually meet much more frequently. According to the President of Toshi University,

... the three jomuriji and myself get together once per week and we eat lunch together almost every day. Whenever the jomuriji and myself get together, running the school is almost always the topic of our conversation. (Personal Communication, June 1999)

Ministry of Education. The Ministry of Education also plays an important role in decisions related to finance and management because of its authority over the school establishment approval process and the limited subsidies it provides to private universities. This authority, however, has been growing weaker each year as private universities are forced to rely less on government subsidies and more on tuition income, for-profit activities and private donations. Toshi University now receives less than $30 \%$ of its financial support from the government's Private School Assistance Act of 1975, and this subsidy has been reduced by over half since 1980 as worsening economic factors put stringent limitations on increases in government subsidies. Many of the faculty and 
administrators interviewed predicted that some private institutions that depend heavily on tuition and fees will face the prospect of bankruptcy if they cannot attract sufficient numbers of students. Although none of the people interviewed suggested that such a fate was possible for Toshi University, almost everyone expressed concern about the situation and indicated that changes were needed to deal with the situation.

According to the President of Toshi University, changes have also occurred in how the Ministry provides funding to the private universities. At one time, Toshi University received unrestricted funding that was intended for the overall institution. Now the funding is for specific programs with preference given to those courses that characterize the uniqueness of the institution. The Ministry's intention is to promote uniqueness in the educational system and eliminate redundancy where several institutions offer the same types of programs. According to an official in the Ministry of Education's Bureau of Private Higher Education, the Ministry also sets limits on the number of students a private school can admit and enroll for each department and college. Also, when a private university decides to establish a new department or college, it must obtain approval from the Ministry and show that the new department or college will be financially viable. Given the control the Ministry exerts over enrollment and school establishment coupled with the fact that private universities in Japan are heavily dependent on tuition revenue, the Ministry of Education has considerable influence over a university, like Toshi. 


\section{The 1998 University Council Reforms and their Impact on the Financial}

\section{Affairs at Toshi University}

Immediately following the reform proposals by the University Council in October 1998, the Ministry of Education began its efforts to revise selected education laws and ordinances. In order for universities to begin implementing the various reform recommendations, the University Council proposed that more authority be given to the universities' administration and more governing autonomy be given to the individual university and its president. The call by the University Council for greater autonomy of the university and stronger decisionmaking power for the university's administration was perhaps the most controversial item in the Council's report because it suggested that the decisionmaking authority of the faculty and Ministry of Education should be weakened. Private universities were affected by the reform to give state-run universities more autonomy because (1) the regulatory control by the Ministry over private universities would be relaxed and government subsidies proportionately reduced, and (2) privatization of national and public universities would change the dynamic of the competition for the dwindling number of students.

With the 1998 reforms, both private and public universities are reacting to the University Council's recommendations. However, public universities appear the most directly affected because most of the tuition-dependent private universities, unlike their heavily-subsidized public counterparts, have already made the kinds of changes proposed in the reforms to deal with the declining college-going cohort. For example, the Kyoto College Consortium, a cooperative 
arrangement between 46 two-year and four-year colleges in Kyoto was reached five years ago, and over 6,000 students are expected to cross-register in classes at other consortiums of private colleges during the 2000 academic year ("College Reform," 2000). Toshi University has belonged to such a consortium for over three years and currently has a cooperative arrangement for transferring credit with over 20 four-year colleges located in its geographical area.

\section{Faculty Perceptions about the 1998 University Council Reforms and their}

\section{Implications for Administrative Governance at Toshi University}

As indicated in Table 23, the 1998 University Council reforms encourage a strong central leadership, like the one found at Toshi University, and recommend that vice-presidents, deans and faculty members assist the president to make necessary proposals and plans for the university administration. While Toshi University does not have vice presidents, the full-time members of the Board of Trustees function similar to vice-presidents at universities in the United States, each representing a different general area of governance, but generally concerned with the non-academic areas of governance, particularly the area of financial affairs. The frequent meetings that the President has with the trustees function as cabinet meetings with vice-presidents. The President also attends the Deans' Council meetings, and the deans assist the President with the academic governance, but they rarely participate in the decision-making related to financial affairs. Faculty members serve on both the Board of Trustees and Deans Council. According to the survey, the majority of respondents, about $83 \%$, agreed that the president should be assisted by vice-presidents, deans and 
faculty members assigned by the President to make necessary proposals and plans for the university administration.

Table 23

All Faculty Respondents Indicate their Opinions about Proposals for Reforming the Existing University System Japan as Recommended Recently by the University Council

\begin{tabular}{|c|c|c|c|c|}
\hline Proposals & $\begin{array}{l}\text { Mostly } \\
\text { Agree }\end{array}$ & $\begin{array}{c}\text { Mostly } \\
\text { Disagree }\end{array}$ & $\begin{array}{c}\text { No } \\
\text { Opinion }\end{array}$ & $\begin{array}{c}\text { No } \\
\text { Answer }\end{array}$ \\
\hline $\begin{array}{l}\text { The president should be assisted } \\
\text { by vice-presidents, deans and } \\
\text { faculty members assigned by the } \\
\text { president to make necessary } \\
\text { proposals and plans for the } \\
\text { university administration. } \mathrm{N}=86\end{array}$ & $\begin{array}{c}71 \\
(82.55)\end{array}$ & $\begin{array}{c}5 \\
(05.81)\end{array}$ & $\begin{array}{c}10 \\
(11.62)\end{array}$ & 10 \\
\hline $\begin{array}{l}\text { Presidents and deans should be } \\
\text { responsible for making decisions } \\
\text { about financial affairs and } \\
\text { personnel and take responsibility } \\
\text { for administration. } \mathrm{N}=85\end{array}$ & $\begin{array}{c}50 \\
(58.82)\end{array}$ & $\begin{array}{c}16 \\
(18.82)\end{array}$ & $\begin{array}{c}19 \\
(22.35)\end{array}$ & 11 \\
\hline $\begin{array}{l}\text { Present colleges and universities } \\
\text { are so big and complex that it is } \\
\text { necessary to train professional } \\
\text { administrators and managers of } \\
\text { higher education. } \mathrm{N}=84\end{array}$ & $\begin{array}{c}48 \\
(57.14)\end{array}$ & $\begin{array}{c}11 \\
(13.09)\end{array}$ & $\begin{array}{c}25 \\
(29.76)\end{array}$ & 12 \\
\hline
\end{tabular}

The 1998 reforms also recommend that the presidents and deans should be responsible for making decisions about financial affairs and personnel. At Toshi University, the deans do not play a significant role in decisions related to financial affairs, although they are involved in personnel decisions. About $59 \%$ of 
the faculty agreed with this recommendation and about $19 \%$ of the faculty reported that they disagreed, receiving the highest disapproval rating. No comments were offered on this part of the survey, so source of the disapproval is unknown. At some private universities, deans are involved in the financial decision-making; however, at Toshi University, the Board of Trustees is the body responsible for this area of governance. Perhaps the faculty members at Toshi University do not support giving more decision-making responsibility over the financial affairs to the Deans' Council, or perhaps they believe that the deans should have less authority in personnel matters. This recommendation was likely intended more for national and public universities because it does not even mention the role of a Board of Trustees in making decisions related to personnel and financial affairs.

The final item on this part of the survey was expected to get overwhelming agreement; however, it received the lowest approval rating of the three items with only a little over half of the survey respondents in agreement that training is necessary for professional administrators and managers of higher education. In the United States, this idea is widely accepted in the higher education community, while it appears that in other countries, like Japan, university administration is still not considered a valid profession.

\section{Governance over External Affairs at Toshi University}

At Toshi University, mutual interaction with the external environment occurs on an institutional-level through the Board of Trustees and the President. 
The Board of Trustees at Toshi University includes four part-time members from the external community. These part-time trustees are usually business and political leaders who represent the formal link between Toshi University and its outside community. The groups with which the private universities in Japan interact include alumni, the parents of current and prospective students, the business community (which employs the graduates), private industry (and other sources of funding and collaboration for research), and the general public. Compared to universities in the United States, private universities in Japan are still much less involved in affairs outside the academic community. Like most universities in Japan, Toshi University has very little official communication with the outside environment, but this situation is changing due to government reforms that are encouraging more openness and interaction with the public.

Alumni. Much of Toshi University's communication with the external environment is informal, the university having no offices for community development or external affairs. The system for conducting alumni relations at Toshi University is still in its infancy and the university does not have an administrative unit that solely focuses on alumni relations. According to the President of Toshi University,

Because our funding depends $80 \%$ on tuition, we do not have the same motivation to interact with the community as you might find in the United States. Alumni support and private giving is very minimal, which is typical in Japan. We are planning to launch major funding drives; however, we 
have a long way to go because the prevailing attitude in Japan is that once you graduate it’s "sayonara." (Personal Communication, June 1999)

Despite the limited infrastructure dedicated to alumni relations, Toshi University has begun efforts to increase its relations with alumni. The President initiated continuing education programs about two years ago and markets the programs specifically to the alumni through a direct mailing campaign. The President says the program has been highly successful as a public relations tool and brings hundreds of alumni to the campus each year to see first-hand the University's progress.

While perhaps not a top priority at Toshi University, alumni do play an important role in the university's decision-making process in terms of their influence. Many alumni find employment at Toshi Academy after they graduate, especially as staff in the administrative offices, but also as faculty and administrators. According to one faculty member,

The large number of alumni working at Toshi University in decisionmaking roles has a much greater impact on the administrative system than any reform from the Ministry. I know of very few administrators who are not alum of Toshi University. I've heard that the director of human resources has been trying to get consensus at the Deans' Council to limit the number of alumni that are employed at Toshi University, but he has faced some opposition. (Personal Communication, June 1999) 
Since many of the faculty and almost all of the staff at Toshi University are graduates, they give a great deal of pride and loyalty to the University. According to Reischauer (1988),

Major universities have the ideal of staffing themselves exclusively from their own graduates and achieve this goal to a surprising degree. Very few students attend more than a single university, and throughout life individuals identify themselves and are identified by others on the basis of the university they attended in a way that finds only a pale reflection even among Ivy League schools in the United States. (p. 134)

Parents. The parents of current and prospective students are of great concern to the university administration who want to make their programs appealing for students, but more importantly, they want to make the programs appealing to the parents who pay the tuition. For example, in his "State of the University" speech given in April 1999, the President of Toshi University attributed many of the objectives for the recent curriculum reforms to the expectations voiced by parents of the students attending the Toshi Academy Secondary School.

Business. The links between business and university have always been evident in Japanese higher education. However, only recently has so much discussion in the higher education community dealt with tailoring university curriculum to meet the needs of employers. Toshi University has increased efforts to reach out to the business community. The Office of Academic Affairs and the Office of Institutional Research are responsible for conducting surveys of 
businesses (as well as parents and alumni) to collect data on employers' needs and their satisfaction with the graduates who obtain jobs there. According to the President,

We do listen to what the business community has to say, in that they are receiving many of our students. We will sometimes survey the business community to get a better idea of how to develop our curriculum to meet the needs of the employer. (Personal Communication, June 1999)

Companies are now placing more value on the candidate's quality of scholarship gained through a four-year educational process rather than on the score gained on the university entrance examination. Traditionally, Japanese have believed that career opportunities primarily depend on the educational institution one attended. Arimoto (1997) notes that many companies are already abolishing the practice of recruiting candidates based on whether they attended one of the "shiteiko," or designated schools, such as University of Tokyo or Waseda University, which require the highest scores on the entrance examinations. Institutions like Toshi University are responding to this change of attitude by revising its curriculum and establishing new programs that emphasize business management, information technology, and other areas in demand by business.

Industry and Other Sources of External Funding. According to Arimoto (1997), cooperation between commercial enterprises and universities, even national universities, has been increasing. Institutions are seeking money and resources through the establishment of cooperative research centers and 
donations. The current trend represents a significant change in the faculty's attitude toward university involvement with the outside community. Yamamoto (1993) discusses the challenges of overcoming traditionalism at Japanese universities in order promote research and development:

Unlike the public, which had accepted scholarly detachment and traditionalism more out of respect than anything else, professors have believed, and still do, that universities should stay aloof from whatever is parochial and anti-intellectual. The only outsiders accepted in the academic community have been students who must prove themselves worthy. However, the growing demand for accountability and the changes in science and technology support have forced universities to change. (pg. 48)

At Toshi University, faculty members have gained prominent roles in the university-wide decision-making process due to their involvement in high-profile research projects that bring funding and prestige to the University. According to one dean at Toshi University, a faculty member's outside contacts in the government and business world can become valuable assets to the university, which in turn can help to empower that faculty member's position:

As a dean, I can initiate change at Toshi University. I can bring issues up at the Deans' Council and I can even go directly to the President if I want. For the average faculty member, it is much more frustrating. The faculty member must get consensus within their [sic] own department, but there are occasions where faculty members go directly to the dean or even the 
president. However, in this case, it helps to have contacts in the Ministry or in big business or have access to research funding if you want your voice to be heard. (Personal Communication, June 1999)

For the most part, private universities have been more willing to adjust their research activities to the needs of private industry and the general public than their national and public counterparts. This is probably because private universities have more decision-making power over planning budgets and distributing resources than the public universities that must defer to the Ministry of Education. At Toshi University, most faculty members agree that research should address the needs of the community and business. About $73 \%$ of the faculty respondents agreed (see Table 24) that faculty research should be more sensitive to community and business needs, and very few faculty disagreed with this trend.

\section{Table 24}

Faculty Respondents' Agree or Disagree that Faculty Research Should be More Sensitive to Community and Business Needs

\begin{tabular}{lcccc}
\hline & $\begin{array}{c}\text { Mostly } \\
\text { Agree }\end{array}$ & $\begin{array}{c}\text { Mostly } \\
\text { Disagree }\end{array}$ & $\begin{array}{c}\text { No } \\
\text { Opinion }\end{array}$ & $\begin{array}{c}\text { No } \\
\text { Answer }\end{array}$ \\
\hline Arts and Education & 27 & 1 & 7 & 8 \\
$\mathrm{~N}=35$ & $(77.14)$ & $(02.85)$ & $(20.00)$ & \\
Agriculture & 15 & 1 & 7 & 1 \\
$\mathrm{~N}=23$ & $(65.21)$ & $(04.34)$ & $(30.43)$ & \\
Engineering & 20 & 4 & 3 & 2 \\
$\mathrm{~N}=27$ & $(74.07)$ & $(14.81)$ & $(11.11)$ & \\
University-wide & 62 & 6 & 17 & 11 \\
$\mathrm{~N}=85$ & $(72.94)$ & $(07.05)$ & $(20.00)$ & \\
\hline
\end{tabular}




\section{The 1998 University Council Reforms and their Impact on the External}

\section{Affairs at Toshi University}

The role of universities in Japan in relation to the public is changing. A growing call by the public demands that universities should address real-world economic and social needs. In response, the University Council has initiated reforms that have led to self-evaluation processes at each university. The 1998 reform recommendations sought to create more healthy competition among universities in light of the dwindling numbers of students and limited state subsidies. To do so, the government, as recommended by the University Council reforms, has begun to give greater autonomy and power to the individual universities. In exchange, it expects universities to become more accountable to the public by setting up self-evaluation systems, both internal and external, and publicizing these assessments. According to Arimoto (1997), the United States first introduced the concept of external evaluation after World War II, but the concept has become accepted only recently in Japan. The University Accreditation Association (Daigaku Kijun Kyokai) began conducting evaluations of its 169 member institutions in 1996, the first example of external academic evaluation in the history of Japanese higher education. As a result of the 1998 reforms, external evaluations may soon become mandatory for all public and national universities, and perhaps even private universities.

In fact, in January 1999, the Ministry submitted a bill to the Diet to amend the law concerning the establishment of national universities to include a clause on information disclosure ("Release of Information," 1999). The Ministry of 
Education also announced its plans to introduce similar revisions for other public and private universities. The Ministry of Education might eventually require private universities to adopt a third-party evaluation system that would determine how much funding they would receive from the government, similar to what is now being implemented in the public university sector. Currently, private universities have only been encouraged--not required--to accept external evaluation.

According to the Ministry of Education, numerous universities are now publishing the findings of their external evaluations, including colleges and departments at the University of Tokyo, Hiroshima University and Kyoto University. Also, many private universities are publicizing the results of their selfevaluation reports and distributing the publications to secondary schools, public libraries and boards of education for public viewing. Some private universities have also established councils to evaluate their management systems and have invited outside experts from private industry to serve on the councils. At Toshi University, the Office of Institutional Development coordinates the assessments of the university, and some of its findings are published in reports available to prospective students and their parents. Each college and department also publishes information about its programs and research projects on its school website. According to the President of Toshi University, future self-evaluations may utilize the techniques of Total Quality Management and allow for widespread participation in a continual assessment of both the academic and administrative processes of the university. Higher education and management experts may 
also be invited to participate in the evaluation. Currently, the Future Planning Committee, that meets each summer, carries out assessments and makes recommendations for changes; however, the reports are usually not made public, but used for internal purposes only.

\section{Faculty Perceptions about the 1998 University Council Reforms and their}

\section{Implications for Governance over External Affairs at Toshi University}

A study by the Research Institute for Higher Education (1991) reported that many faculty accept the need for reforming the university, but they are reluctant to take action, except for an elite group of professors who are actively engaged in the issue of higher education reform. According to the study, this circumstance is especially true in the area of self-evaluation where faculty members are usually encouraged to serve on self-evaluation committees, but they are sometimes reluctant to participate actively in the process. This does not appear to be the case at Toshi University. According to the faculty survey results (Table 25 ), the majority of the respondents, about $67 \%$, agreed that faculty should be required to participate in self-evaluations of the University. 
Table 25

Faculty Respondents' Agree or Disagree that Faculty Should be Required to Participate in the Self-Evaluation of the University

\begin{tabular}{lcccc}
\hline & $\begin{array}{c}\text { Mostly } \\
\text { Agree }\end{array}$ & $\begin{array}{c}\text { Mostly } \\
\text { Disagree }\end{array}$ & $\begin{array}{c}\text { No } \\
\text { Opinion }\end{array}$ & $\begin{array}{c}\text { No } \\
\text { Answer }\end{array}$ \\
\hline Arts and Education & 28 & 0 & 7 & 8 \\
$\mathrm{~N}=35$ & $(80.00)$ & $(00.00)$ & $(20.00)$ & \\
Agriculture & 8 & 3 & 11 & 2 \\
$\mathrm{~N}=22$ & $(36.36)$ & $(13.63)$ & $(50.00)$ & \\
Engineering & 20 & 4 & 3 & 2 \\
$\mathrm{~N}=27$ & $(74.07)$ & $(14.81)$ & $(11.11)$ & \\
University-wide & 56 & 7 & 21 & 12 \\
$\mathrm{~N}=84$ & $(66.66)$ & $(08.33)$ & $(25.00)$ & \\
\hline
\end{tabular}

\section{Summary}

This chapter provided a description of Toshi University, its history, academic organization, mission, students, faculty, and governance processes. It also reported perceptions of the university governance process by the faculty and their attitudes toward the recent changes affecting teaching and research using the results of a survey distributed to all of the faculty at Toshi University. This was followed by an ethnography of the documents and media accounts that pertain to the 1998 reforms. An analysis was then provided, which included a description of the governance processes at Toshi University related to its academic, administrative and external functions of decision-making. The 1998 University Council reforms were discussed in relation to each of these functions of governance, including faculty's responses to the emerging issues resulting from the reforms. 


\section{Chapter 5}

\section{Discussion of Findings}

This chapter will discuss the findings in relation to the problem statement and research questions, and will then relate the findings to theories and concepts used to analyze governance patterns, namely the bureaucratic, collegial and political models, as well as three authority structures and various aspects of Japanese culture discovered at Toshi University.

\section{Discussion of the Findings in Relation to the Problem Statement}

The case study examination of governance at Toshi University sought to answer the following question:

What are the differences between the patterns of governance at Toshi

University before and after the 1998 University Council reforms?

The research findings demonstrate that bureaucratic, collegial and political patterns of governance were all present before and after the 1998 reforms. As discussed in Chapter 2, these three patterns of governance are major Westernbased conceptual models that have evolved from the organizational theory. These major theoretical models by themselves do not adequately describe all of the governance patterns present at Toshi University. Several authority structures are present as well, including professional authority, trustee authority and personal authority. These structures were all observed both before and after the 1998 reforms. In addition, some patterns of governance specific to Japanese culture are either found in isolation or in combination with the Western-based 
models. The 1998 reforms have served to either strengthen or weaken these various patterns of governance with respect to one or more functions of decisionmaking, namely academic programs and instruction, faculty affairs, financial affairs, or the relationship with the key parts of the University's environment.

The Bureaucratic Model. The bureaucratic model was reflected in the governmental regulations imposed on Toshi University by the Ministry of Education, particularly in the areas of financial and academic affairs. This model is based on Max Weber's theory of bureaucracy and is characterized by an organizational hierarchy of authority, systematic application of rules and regulations, and divisions of labor. The authority of the Ministry of Education is more clearly evident in the administrative affairs of Toshi University than in the academic domain that is more familiar to the average faculty member. This finding might explain why the majority of the faculty who were surveyed reported that they were less concerned with the Ministry of Education as a decisionmaking body than they were with the President or the Faculty Council. Most of the faculty at Toshi University are unfamiliar with the Ministry of Education and its role in their University's governance process, as reflected in the large number of non-responses on survey items related to the Ministry of Education. On the other hand, a small number of faculty at Toshi University (as was shown in Tables 15 and 16) felt their authority had been weakened by the Ministry of Education reforms. About $18 \%$ of the faculty respondents reported that they felt their authority over the curriculum had been weakened, and about $11 \%$ indicated that they felt less empowered over matters related to faculty affairs. Overall (as was 
seen in Table 19), about $23 \%$ of the respondents indicated that they thought the Ministry of Education still exerts "too much" influence over the decision-making at their school, especially with regard to academic programs and instruction.

However, it is probably in the area of financial affairs and the other managerial activities of the university where the bureaucratic power of the Ministry of Education is strongest, especially with regard to the regulations over enrollment and the establishment of new departments and colleges. The 1998 reforms recommend that the president and deans should be responsible for making decisions about financial affairs and personnel. The majority of faculty at Toshi University appear to agree with the 1998 reform recommendation that the president should be primarily responsible for making decisions related to personnel and financial affairs, and that less power should be allotted to the Ministry of Education. Actually, this is already the case at Toshi University, so the reform only serves to reinforce the strong presidential leadership authority that currently exists. While the bureaucratic patterns of governance will continue to grow weaker with the relaxation of the Ministry of Education regulations over the academic governance due to the 1991 and 1998 University Council reforms, these patterns will probably remain at the same level within the administrative governance processes at Toshi University.

Another aspect of the bureaucratic model is seen in the decisions that the administrative staff at Toshi University carries out according to the goals and objectives set by the President. These goals and objectives are communicated in the President's State of the University address that he gives at the beginning of 
each year on April 1. The speech is published as a report and distributed to all of the managers of the administrative divisions and offices, who, then use the goals and objectives to develop proposals and plans for their respective divisions.

The Collegial Model. The collegial model, which is grounded in "human relations" theory, is more decentralized than the bureaucratic model, emphasizing community, shared decision-making and consensus. The collegial model is reflected in the traditions of the Future Planning Committee and the limited representation that faculty maintain in the Faculty Councils at Toshi University, especially with regard to academic governance. Chapter 4 noted that the most significant changes to the curriculum during the past five years at Toshi University were revisions made to the general education requirements. According to the President of Toshi University, faculty members in each of the colleges and departments carried out the revisions, which would suggest a certain level of collegiality was present in the decision-making process. However, these collegial patterns have been largely restricted to academic governance, rather than administrative governance.

The results from Table 13 showed a large number of faculty, as many as $40 \%$ of the survey respondents, who believed that the changes in their college over the past five years have been mostly negative. The faculty's resistance to change, despite their collegial participation in the decision-making process, is an interesting point to ponder. This high level of disapproval pertained to the curricular changes that were based on the Liberal Arts model found in the United States where all students must satisfy a general education requirement before 
they begin to take courses in their major. It is the assumption of the researcher (based on some on the interviews with various faculty members) that the resistance of the faculty toward this change comes mainly from the senior faculty members who are unwilling to accept new ideas that depart from the traditional Japanese system. The younger faculty members, on the other hand, appear more supportive of the changes. They are also more open to new ideas and new situations in general, as reflected in the above-average number of younger faculty who responded to the researcher's survey on governance, while the senior faculty respondents were surprisingly underrepresented in the survey results. The collegial patterns of governance will probably be strengthened in the future as more of the senior faculty retire and are replaced with younger faculty.

The 1998 reforms are also likely to have direct implications on the collegial patterns of governance at Toshi University. According to the faculty survey results (as shown in Table 25), the majority of the respondents, about $67 \%$, agreed that faculty should be required to participate in the self-evaluation process of the University, which the reforms recommend should include faculty participation. As the self-evaluation component in the 1998 reforms becomes more widespread, collegial patterns will certainly be strengthened at Toshi University. Toshi University may possibly someday form a faculty senate that promotes greater collegiality of the faculty at the university-wide level, but this change is unlikely soon. The 1998 reforms recommend that universities specify the basic functions of a senate and a faculty council respectively, but does not go so far as to recommend that all universities should actually have a faculty senate. 
As the survey results suggest, a faculty senate model at Toshi University would either have to be imposed by the Ministry of Education or strongly encouraged by the President to be successful due to faculty division on this issue. As seen in Table 21, while over half of the faculty respondents agreed that Toshi University should have a faculty senate with limited decision-making authority over academic affairs, this survey item also received the highest rate of disapproval with approximately $26 \%$ of the respondents indicating that they disagreed with the reform proposal related to governance by a faculty senate.

The Political Model. The political model, unlike the bureaucratic and collegial models, accounts for the conflict that is often found in an organization. The major components of the political model are conflict, interest groups, political elites, democratic factors, compromises, and external influences (Baldridge, 1971a). The political model is reflected in the environment of the market economy in which Toshi University must operate where student enrollment determines to a large extent how its resources are to be allocated. In this case, the more popular programs with the strongest enrollment receive the larger share of resources.

The deans play a major role in the political dynamic of the decisionmaking at Toshi University. It is the responsibility of the deans to coordinate the vested interests of their faculty through their participation in the Dean's Council meetings, but more importantly through their personal interaction with the President. In fact, the President remarked in an interview with the researcher that it is his personal relationship with the Dean that often determines whether or 
not a proposal is initiated. One of the faculty members at Toshi University mentioned in an interview that contacts in the Ministry or in big business or access to research funding sometimes make it possible for a faculty member to by-pass the Dean and gain direct access to the President. Perhaps to a lesser extent than having important contacts in business or government, alumni status may also provide a faculty or staff member with a certain amount of political power. The political pattern will continue to the same degree after the 1998 reforms, and may be strengthened due to the heightened competition from the national universities for the dwindling college-cohort. On an institutional level, political patterns of governance can be seen in the coalitions that will certainly increase between universities, even between public and private universities, in order to capture a greater market share of the college cohort. These coalitions are already seen in the various consortiums for articulating credit that are developing, but will likely soon evolve into mergers between institutions for mutual financial benefit.

Professional Authority Structure. Although closely related to the collegial model, professional authority provides a more accurate orientation for some of the faculty groups at Toshi University whose authority is based on expertise, research specialization and professional association. Professional authority is reflected in the senior faculty members at Toshi University who exercise dominion over their teaching and research based on traditionalism. In fact, Toshi University has a higher percentage of full and associate professors than the average university in Japan and, according to the survey results, many 
of these faculty are strongly oriented toward research, especially in the colleges of Agriculture and Engineering. The research findings also demonstrate that the administrative and governance roles at Toshi University are largely restricted to the most senior full professors with long years of service at the University. Despite their power in numbers and rank, the professional authority structure appears to have been stronger before the reform and has since been significantly reduced. The weakening of the professional authority can be primarily attributed to the President who initiated a change soon after becoming president that required departments to standardize their specialized curriculum based on the content of the program. Before that time, the requirements for the major areas of study were much less standardized and were more dependent on who taught the courses, rather than what was being taught. The increased autonomy that Toshi University has achieved as a result of the 1991 and 1998 University Council reforms has made it possible for the President to initiate these widespread changes in the curriculum.

Trustee Authority Structure. Another authority structure found at Toshi University is trustee authority, which is derived from the corporate nature of Toshi University and characterized by formal decision-making and accountability of the institution to the public. Trustee authority is reflected in the Board of Trustees who make all of the financial decisions and are responsible for maintaining accountability to the Ministry of Education, the parents, the business community and the financial viability and legal requirements of the school corporation. One of the more surprising results from the surveys was the low number of faculty 
who indicated concern about the decisions made by the Board of Trustees. As shown in Table 17, only 7\% of the respondents reported that they were "deeply" concerned about the Board of Trustees, and almost 30\% reported that they were indifferent to the decisions made by the Board of Trustees. In fact, the faculty were more concerned about the decisions made by the Faculty Council, the President, the Ministry of Education and the Dean's Council than they were about those by the Board of Trustees.

Yet the Toshi University Constitution describes the Board of Trustees as the supreme authority over all administrative and academic affairs at Toshi University. It is likely that the power of the Board of Trustees is only nominal and the decisions made by this body of governance are more formalized and predictable. Though never stated in any of the interviews with the administrators, the researcher reached this conclusion based on observations and the results from the survey. Trustee authority is therefore present at Toshi University, although to a much lesser extent than the personal authority of the President. Moreover, there are no indications that this authority structure will be weakened or strengthened in the future as a result of the reform. In fact, boards of trustees are not even mentioned in any of the 1998 reform recommendations, perhaps because this body of governance does not exist at national and public universities.

Personal Authority Structure. Strong personal authority is also evident at Toshi University and is characterized by the paternalism of a single leader. This authority structure is reflected in the monocratic authority of the President at 
Toshi University who draws much of his power from his ownership of the corporation. The President's leadership is strongly supported by the majority of the faculty, which suggests that his power is also based on charisma. The 1998 reforms recommend that the President should be the one who sets the objectives and makes plans for education and research for the university at large. According to the survey results (shown in Table 21), the majority of respondents, about $60 \%$, agreed that the President should play the central role in the academic governance. All of the faculty and staff interviewed by the researcher indicated that the President was a strong and effective leader who is capable of making change at his institution.

The concept of leadership was briefly discussed in Chapter 2 and its relationship to a research study dealing with governance was examined. Studies have been conducted that have compared and contrasted presidential leadership across cultures. For example, Trow (1987) found that presidents in the United States tended to be stronger leaders than their counterparts in Europe. According to the higher education research in Japan, the majority of Japanese universities are populated with presidential leaders who are unable to affect change on their institution, especially in the national and public universities, but also at many private universities where the faculty dominate the governance process. This situation is not the case at Toshi University, where the President is also the Chairman of the Board of Trustees and takes a very active role in the management and leadership of his institution. This strong personal authority 
structure at Toshi University will likely be strengthened in the future due to the 1998 reforms that calls for a strong president at the center of governance.

\section{Toshi University College of Business}

In order to provide a broader perspective on the differences between the patterns of governance before and after the 1998 reforms, the five research questions (listed at the beginning of Chapter 1) will be presented and discussed in relation to one of the most important single events in the recent history of Toshi University: the decision to establish a new College of Business though made prior to the 1998 reforms, many decisions associated with the implementation of the college also occur after 1998. Moreover, the decision involved all aspects of the university governance, including the decision-making over academic, faculty, financial and external affairs. For this reason, the decision to establish a new college will serve as the point of reference for discussing the five research questions. However, before proceeding with this presentation of each one of the research questions, a discussion will begin with a description of the new College of Business. This discussion will not attempt to draw any conclusions, only present the findings related to the decision to establish a new college.

\section{Background on the Establishment of the New College}

At Toshi University, the establishment of a new College of Business is one of the most important new developments in the past thirty years of its history. Encouraged by the revisions of the standards for university establishment in 
1991 and the 1998 University Council reforms, hundreds of public and private universities in Japan have been establishing new colleges and departments in order to attract new students. The trend is the product of university leaders in Japan who have been seeking ways to make their institutions more unique, more competitive and more responsive to various environmental pressures, such as the declining 18-year-old cohort. Arimoto (1997) predicts that the current trend may eventually constitute the most substantive changes to occur since the postwar reform, because for the first time, the changes are taking place internally and they are self-directed. In some cases, the establishment of these new colleges and departments has been purely cosmetic, a restructuring that is nothing more than renaming the college or department and keeping the same staff and facilities as before.

The College of Business is the first new college at Toshi University since the Junior College for Women was established in 1964. Since that time, numerous movements have attempted to establish new colleges, but none have been successful until now due to internal reasons or rejections by the Ministry of Education. According to one of the senior faculty members at Toshi University, Many years ago there was a movement to establish a College of Education; however, because of our aging population and reduced need for teachers, this did not work out. There were also discussions to establish a College of Fine Arts, but it was later determined that it would be too costly. A College of Foreign Languages was also proposed at one time, but we found that we could not guarantee the needed numbers and 
the foreign language training market is already flooded in Japan. A College of Business probably has a much better chance for being implemented and many people have always felt uncomfortable with the international management courses under the English and American Literature Department in the College of Arts and Education. (Personal Communications, June 1999)

The President of Toshi University made his first official, public announcement about the new College of Business in his State of the University address in April 1999. In his speech to the faculty and the entire freshman class, he indicated that the new college would be a world-class business school that would incorporate the unique educational philosophy found in all programs of study at Toshi University. He promised that the school would also educate students to be "global citizens" with a "public mind" who are competent in using English as an international language and who possess skills and the knowledge to use information technology and manage business organizations:

...the new-era managers need to have not only a sense of making money, but also a sense of truth, goodness, beauty, holiness, health and wealth that make it possible for a business professional to manage consistent with the standards of an international society. (President of Toshi University's State of the University, Transcript of Speech, April 1999) 


\section{Mission and Academic Organization of the New College}

The President's State of the University remarks are reflected in the mission statement of the new school: (1) to develop business leaders who can assume the responsibilities inherent in a global society; (2) to develop human beings with public concerns who can do business in the global network, and (3) to establish research institutes where one can learn business management that is fair and consistent with global standards.

The curriculum of the new college places a heavy stress on communicating and understanding English as an international language and computer literacy. The first two-years of study share the same liberal arts-based foundation of courses found in the other colleges at Toshi University with additional courses in the field of business and international studies. Students must also take courses in English as a foreign language and computer literacy, and all students are required to bring a laptop computer to their classes. Upperdivision courses include Macroeconomics, Microeconomics, Accounting, International Relations, Business Leadership, and Business Ethics. The fouryear degree program will also require students to study abroad, and participate in an international internship program where they will gain experience working at an international business firm. The school will allow students to transfer up to 60 hours of credit, more than twice allowed by the other colleges at Toshi University. Upon graduating, students are expected to have sufficient English language ability to pursue academic study at a college or university in an English-speaking country. The College of Business will open with only one department, the 
Department of International Business Management, which will enroll 180 students for its first freshman class in April 2001. Some of the faculty will transfer from the College of Arts and Education where they have been teaching business courses in the Department of English and American Literature, and others will be new faculty members at Toshi University. The college is expected to expand during the next ten years with additional departments and graduate programs.

\section{The Process of Establishing the New College}

The history of the College of Business can be traced back to the Future Planning Committee sessions in 1995 and 1996 (see Figure 4). Since then, administrators and faculty have been working together to develop a proposal for establishing the new college at Toshi University. In order to establish a new school in Japan, it is necessary to submit a proposal to the Ministry of Education and obtain approval before recruiting students and marketing the school. The acceptance of the proposal is based on its strict conformity to the recently revised University Establishment Standards, an ordinance from the Ministry of Education in the School Law of 1947 that prescribes standards for academic staff qualifications, framework for curricula, graduation requirements, and minimum facility/equipment standards. In the case of private universities, a successful proposal must also demonstrate financial viability. 
Figure 4

\section{Establishment of College of Business \\ Timeline of Events and Committees}

1994 Toshi University President

Takes Office

1995

1996 Future Planning Committee Makes Proposal to Establish a College of Business to President

1997
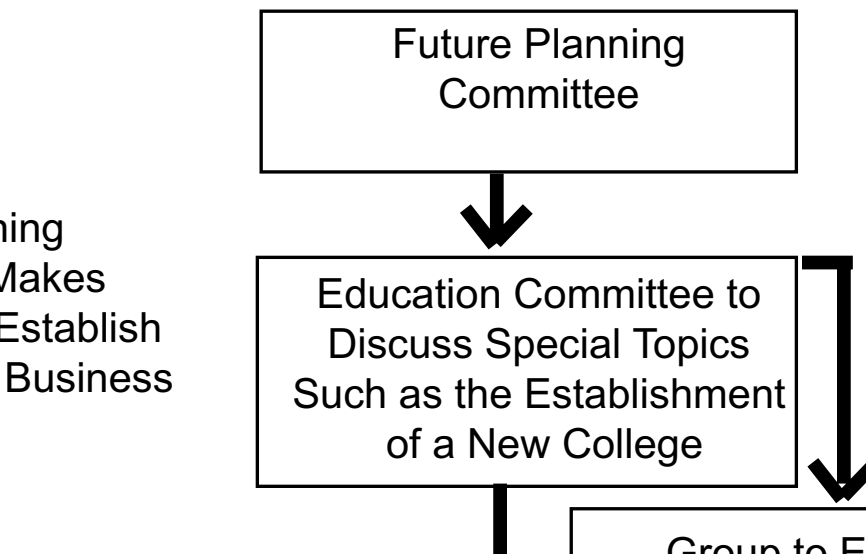

1998 University Council Reforms

1999 College of Business Proposal Announced to All Faculty

President Announces the New College in his State of the University Address

Application to Establish New College Submitted to Ministry of Education

2000 Ministry of Education Approves the New College

Group to Establish New College

Committee to Establish a College of Business Management includes:

Educational Planning Group

External Relations Group 
Early Stages of the Process. According to an administrator who was involved in the planning process from the beginning, the concept of establishing the College of Business developed when several groups began discussing the idea with the direction and support of the President:

First there were discussions among the faculty in the departments of the College of Arts and Education and they talked in great detail about the curriculum and gradually the discussion expanded to the level of the Dean. At the same time, the members of the Board of Trustees were discussing the financial viability of establishing a College of Business. And on another level, but at the same time, the Office of Academic Affairs was conducting research and investigating the marketing potential for this program. (Personal Communications, June 1999)

Eventually, these groups began meeting at the Future Planning

Committee. According to documents provided to the researcher by the Office of Academic Affairs, the group met twelve times at the Future Planning Committee during 1995 and 1996 and reported the outcome of their meetings in October 1996. The Future Planning Committee made the following recommendations in its report:

A new college, which emphasizes social sciences, should be created at Toshi University to meet the current demands of society, the job market and in order to attract the male 18 year-old cohort. The new college should come out of the College of Arts and Education to (1) relieve this college of its heavy administrative burden and to allow for more effective 
research and student instruction, and (2) utilize the business course foundation already established in the Department of English and American Literature. The vision of the new college should borrow from both the business courses found in the College of Arts and Education's Department of English and American Literature and the curriculum in the College of Engineering's Management Engineering Department. The new school should also include an international perspective in its vision. The new college should be related to Business Management in view of the current societal needs, the demand from the graduating high school students and their parents and the current employment trends. (Future Planning Committee Report, October 1996)

Formalization of the Process. With the President's approval, a committee was established to discuss the process of establishing the new College of Business. This committee was called the Education Committee to Discuss Special Topics Such as the Establishment of a New College (gakubu-too kyooiku tokubetsu iinkal) and began meeting from November 1996. This committee consisted of faculty from the colleges of Arts and Education, Agriculture, Engineering and the Junior College for Women, as well as the College of Arts and Education's departments of Education, Drama and Fine Arts, English and American Literature, Foreign Language and the Correspondence Education School. The selection of the faculty to serve on this committee was based on their prior participation on the Educational Improvement Groups of the Faculty Councils in their college, and the Educational Improvement Units of the 
Faculty Councils in their department. Originally, the faculty representatives from the Correspondence Education School had reported to the committee as a Unit, but beginning in April 1999, they began to report as a Group representing their growing independence from the College of Arts and Education.

During the first two years, the members of the committee met about once a month to discuss the various issues related to the establishment of a new college, as well as other special topics concerning the future direction of the University. Most of these meetings were spent discussing the conclusions that had been reached at the Future Planning Meetings during the summers of 1995 and 1996, such as the number of students that would initially be enrolled and the number of departments that would be housed in the new college. The members discussed the impact of the upcoming University Council reforms as they might relate to the establishment of a new college. As a result of the 1998 reforms, the proposal would need to incorporate as many of the reform recommendations as possible, such a GPA system, policies for transferring credit, and a selfevaluation system. The trends for each college and department were also discussed in light of the expected cuts in the Ministry of Education enrollment quotas after the year 2000 and their implications for the new College of Business. In February 1997, the committee decided to establish a sub-committee, called the Group to Establish a New College (shingaku-bu setchi bukai), which would begin meeting in June 1997 to discuss and agree on those items that needed in order to establish the new college. The members of this sub-committee consisted of a smaller group of members from the main committee. These 
individuals, both faculty and administrators who would continue to play major roles in the process of planning the new school and serving on subsequent committees.

The Group to Establish a New College met until October 1998 and discussed the more specific items of establishing a new school, such as the timeline, the name, the curricular objectives, the number of departments, the kinds of courses, minors and majors to be offered, credit transfer issues, and the graduation requirements. The results of the surveys that had been administered by the Office of Academic Affairs to high school students, parents, alumni and business firms were discussed and analyzed. At each meeting, different members took turns making presentations and proposals for the design of the school structure and curriculum. The group also brainstormed ideas for names for the college. In Japan, since names and titles are very important, a great deal of time was spent searching for the appropriate combination of words for the title. The names of other recently established colleges were examined and then discovered that the most popular school titles included the words international, global, environment, information, social welfare, and human. The name of the new college should reflect the goals for the new school that had been communicated by the President while also maintaining its appeal to the Ministry of Education and the students and parents. Fifteen names for the new college were eventually proposed: College of Management (keieigaku-bu), College of Management Science (keieikagaku-bu), College of Social Science (shakaikagaku-bu), College of International Development (kokusai kaihatsugaku- 
bu), College of International Management (kokusai keieigaku-bu), College of Resource Development (shigen kahatsu gaku-bu), College of Human Society (ningen shakaigaku-bu), College of Global Policy (sougou seisaku-bu), College of Global Society (sougou shakaigaku-bu), College of Business Management (keieigaku-bu) and College of Resource Management (shigen keieigaku-bu).

In January 1999, a preliminary proposal for the design of the new college was agreed upon and it was determined that the name for the new school should be the College of Business Management. Also during that month, the Provisional Committee to Establish a College of Business Management (keieigakubu setchi junbikai) replaced the Group to Establish a New College. This was mainly a change in the name of the committee with the same members. In late January, the Provisional Committee presented their plan for establishing the College of Business Management to the faculty at Toshi University in the various Faculty Councils. Some of the special features of the college that drew the greatest reaction from the faculty, both negative and positive, were the advanced English proficiency requirement and the high grade point average required for graduation. Faculty members also reacted, both positively and negatively, to the emphasis that had been placed on communications in the curriculum and the policy that all students would be required to bring a personal laptop computer to school.

In March 1999, the Committee to Establish a College of Business Management (keieigakubu setchi iinkal) was formed and replaced the Provisional Committee as the committee to plan both the academic and administrative 
details of establishing the new school. Again, this was mainly a change in the title of the committee with the same group members. The members were divided into two groups. The first group was called the Educational Planning Group of the Committee to Establish a College of Business Management (keieigakubu setchi iinkai kyooiku keikaku bukal) and it began meeting from April 1999. Its duties were to finalize the academic issues, including number of credit hours to graduate, English proficiency requirements and English language training, internship programs, study abroad programs, the application and registration process, facilities, faculty qualifications and selection, and cooperative research with outside business firms and foreign universities. The second group was called the External Relations Group of the Committee to Establish a College of Business Management (keieigakubu setchi iinkai hoojin taiyoo bukal) and it began meeting from May 1999. Its duties were to discuss the administrative issues involved in obtaining the necessary approvals from the Ministry of Education, as well as planning the budget and finances, staffing, and recruiting students. The procedures for obtaining approval from the Ministry of Education were extremely complex and required some professional consulting from an outside firm to assist the External Relations Group with the application process. During the early stages of the application and screening interviews, the Ministry had some concerns about another private university establishing a College of Business and the competition it might pose to the government-run universities that already had business programs in place. Despite these concerns, the application, which was submitted in October 1999, was successful and Toshi 
University has since obtained the approval to begin enrolling students from April 2001.

The original committee that spawned the ever-evolving group of faculty and administrators that carried out the planning of the new school continued to meet regularly and in parallel with these smaller planning committees. The Education Committee to Discuss Special Topics Such as the Establishment of a New College was more globally oriented to the problems of establishing the College of Business. Its primary function was to address the impact the new college would have on other parts of the University. Specifically, this committee was concerned about the impact of the new school on the College of Arts and Education and how to resolve the potential problems that had been raised in the Faculty Council meetings in the Department of English and American Literature. With the departure of some of their faculty, that department would have to modify its curriculum and there would also be the problem of how to handle the faculty who were presently teaching the business courses in addition to non-business courses in that department.

Faculty Perceptions of the Decision to Establish a New College. The survey results (Tables 26-29), indicate that the majority of faculty members at Toshi University agreed that the decision to establish a College of Business would have a medium or stronger impact on all of the functions of governance. This agreement was strongest with regard to the impact the establishment of the new school would have on financial affairs $(80 \%)$, followed by external affairs (71\%), faculty affairs (65\%), and academic programs and instruction (64\%). 
Table 26

Faculty Respondents' Opinions about the Degree of Impact of the Decision to Establish the New College of Business on Faculty Affairs

\begin{tabular}{lcccccc}
\hline & $\mathbf{1}$ & $\mathbf{2}$ & $\mathbf{3}$ & $\mathbf{4}$ & $\mathbf{5}$ & $\mathbf{N} / \mathbf{A}$ \\
& Strong & & & & Weak & \\
\hline Arts \& Educ & $2(6.89)$ & $4(13.79)$ & $10(34.48)$ & $7(24.13)$ & $6(20.68)$ & 14 \\
$\mathrm{~N}=29$ & & & & & & \\
\hline Agriculture & $1(05.00)$ & $6(30.00)$ & $7(35.00)$ & $3(15.00)$ & $3(15.00)$ & 4 \\
$\mathrm{~N}=20$ & & & & & & \\
\hline Engineering & $5(19.23)$ & $6(23.07)$ & $8(30.76)$ & $2(07.69)$ & $5(19.23)$ & 3 \\
$\mathrm{~N}=26$ & & & & & & \\
\hline University-wide & $8(10.66)$ & $16(21.33)$ & $25(33.33)$ & $12(16.00)$ & $14(18.66)$ & 21 \\
$\mathrm{~N}=75$ & & & & & & \\
\hline
\end{tabular}

Table 27

Faculty Respondents' Opinions about the Degree of Impact of the Decision to Establish the New College of Business on Academic Affairs

\begin{tabular}{lcccccc}
\hline & $\mathbf{1}$ & $\mathbf{2}$ & $\mathbf{3}$ & $\mathbf{4}$ & $\mathbf{5}$ & $\mathbf{N} / \mathbf{A}$ \\
& Strong & & & & Weak & \\
\hline Arts \& Educ & $7(24.13)$ & $5(17.24)$ & $3(10.34)$ & $5(17.24)$ & $9(31.03)$ & 14 \\
$\mathrm{~N}=29$ & & & & & & \\
Agriculture & $1(05.00)$ & $3(15.00)$ & $8(40.00)$ & $2(10.00)$ & $6(30.00)$ & 4 \\
$\mathrm{~N}=20$ & & & & & & \\
Engineering & $10(38.46)$ & $4(15.38)$ & $7(26.92)$ & & & \\
$\mathrm{N}=26$ & & & & & & \\
University-wide & $18(24.00)$ & $12(16.00)$ & $18(24.00)$ & $7(9.33)$ & $20(26.66)$ & 21 \\
$\mathrm{~N}=75$ & & & & & & \\
\hline
\end{tabular}


Table 28

Faculty Respondents' Opinions about the Degree of Impact of the Decision to Establish the New College of Business on the Financial Affairs of the University

\begin{tabular}{lcccccc}
\hline & $\mathbf{1}$ & $\mathbf{2}$ & $\mathbf{3}$ & $\mathbf{4}$ & $\begin{array}{c}\mathbf{5} \\
\text { Weak }\end{array}$ & $\mathbf{N} / \mathbf{A}$ \\
& Strong & & & & & \\
\hline $\begin{array}{l}\text { Arts \& Educ } \\
\mathrm{N}=29\end{array}$ & $9(31.03$ & $4(13.79)$ & $10(34.48)$ & $1(03.44)$ & $5(17.24)$ & 14 \\
Agriculture & $3(15.00)$ & $525.00)$ & $8(40.00)$ & $1(05.00)$ & $3(15.00)$ & 4 \\
$\mathrm{~N}=20$ & & & & & & \\
Engineering & $4(15.38)$ & $2(07.69)$ & $15(57.69)$ & $2(07.69)$ & $3(11.53)$ & 3 \\
$\mathrm{~N}=26$ & & & & & & \\
University-wide & $16(21.33)$ & $11(14.66)$ & $33(44.00)$ & $4(05.33)$ & $11(14.66)$ & 21 \\
$\mathrm{~N}=75$ & & & & & & \\
\hline
\end{tabular}

Table 29

Faculty Respondents' Opinions about the Degree of Impact of the Decision to Establish the New College of Business on External Affairs

\begin{tabular}{|c|c|c|c|c|c|c|}
\hline & $\begin{array}{c}1 \\
\text { Strong }\end{array}$ & 2 & 3 & 4 & $\begin{array}{c}5 \\
\text { Weak }\end{array}$ & N/A \\
\hline $\begin{array}{l}\text { Arts \& Educ } \\
N=29\end{array}$ & $8(27.58)$ & $6(20.68)$ & $9(31.03)$ & $2(06.89)$ & $4(13.79)$ & 14 \\
\hline $\begin{array}{l}\text { Agriculture } \\
\mathrm{N}=20\end{array}$ & $2(10.00)$ & $5(25.00)$ & $6(30.00)$ & $3(15.00)$ & $4(20.00)$ & 4 \\
\hline $\begin{array}{l}\text { Engineering } \\
\mathrm{N}=26\end{array}$ & $5(19.23)$ & $4(15.38)$ & $8(30.76)$ & $3(11.53)$ & $6(23.07)$ & 3 \\
\hline $\begin{array}{l}\text { University-wide } \\
N=75\end{array}$ & $15(20.00)$ & $15(20.00)$ & $23(30.66)$ & $8(10.66)$ & $14(18.66)$ & 21 \\
\hline
\end{tabular}


The widespread agreement by the faculty respondents about the impact the decision would have on financial affairs was also shared by many of the administrators who said that the decision to establish a new college at Toshi University was more financially motivated than academically-oriented. The decision to establish the new college was likely financial, and motivated by a necessity to expand student capacity before the period of declining enrollment makes expansion impossible. Currently, the Ministry of Education regulates the student enrollment at Japanese private universities and sets quotas for how many students each university can enroll over and above an acceptable level of students. From 1992 to 1999, the Ministry of Education allowed Japanese universities to enroll over the number of students normally allowed because of the large number of students who delay their university education for one year to attend "cram schools" and prepare for the next year's exams. These students are referred to as ronin, or "masterless samurai" because they are unable to obtain the necessary test score to enter the school of their choice and are forced to study without a school until they pass the test. Beginning with the 2000 academic year, the Ministry of Education will begin to limit the capacity of students that schools can enroll to offset the decrease in the number of students expected to seek enrollment in the future. Due to changes the government made to the University Establishment Standards in 1991, the establishment of a new college will allow Toshi University to keep its quota of enrollment allocated by the Ministry of Education. It is ironic, however, that despite the declining college-age population, there is a great "rush" to establish new departments and colleges in 
Japan, which is due in part to this loophole in the University Establishment Standards.

The question of whether there was broad support for the new College of Business was addressed in the survey to the faculty at Toshi University. According to the survey results (Table 30 ), only about $13 \%$ of the faculty agreed that there was wide support for the decision to establish the new school and about $22 \%$ reported that there was not wide support. The biggest opposition appears to be in the College of Arts and Education where $30 \%$ of the respondents reported that there was not wide support for the decision in their college. Note that this college is also the one most affected by the decision. The College of Art and Education's Department of English and American Literature currently houses the business-related courses that will be moved (along with some of its faculty and student enrollment quota) to the new College of Business. According to the Dean of the College of Arts and Education, ... the chairman of the Department of English and American Literature is particularly concerned about this event. He is worried that his department will lose its appeal to prospective students, with the loss of these business courses. I think that it will be necessary for his department to work harder to distinguish itself from now on. (Personal Communications, June 1999) 
Table 30

Faculty Respondents' Opinions about whether or not there was wide support for the decision to establish a new College of Business

\begin{tabular}{lcccc}
\hline & Yes & No & $\begin{array}{c}\text { Don't } \\
\text { Know }\end{array}$ & $\begin{array}{c}\text { No } \\
\text { Answer }\end{array}$ \\
\hline Arts \& Educ $\mathrm{N}=40$ & $7(17.50)$ & $12(30.00)$ & $21(52.50)$ & 3 \\
Agriculture $\mathrm{N}=24$ & $1(04.16)$ & $2(08.33)$ & $21(87.50)$ & \\
Engineering $\mathrm{N}=29$ & $4(13.79)$ & $6(20.68)$ & $19(65.51)$ & \\
University-wide $\mathrm{N}=93$ & $12(12.90)$ & $20(21.50)$ & $61(65.59)$ & 3 \\
\hline
\end{tabular}

However, the results reported in Table 30 cannot be generalized because the majority of respondents, about $66 \%$, admitted that they did not know whether or not there was wide support for the establishment of a new college. On the other hand, this large number of "Don't Know" responses does suggest that the majority of the faculty at Toshi University were not involved in the decision.

Wide support for the decision did appear among the various administrators who were interviewed, although a few indicated that they were concerned that the new college would not be able to recruit a sufficient number of students. Some of the reasons given for supporting the establishment of the new college included (1) it compliments the other school offerings at Toshi University, (2) the conditions necessary to establish the school, such as adequate facilities, support of faculty, financing, staffing, student recruitment, etc. are present to justify the decision, (3) there has been an increasing demand among high school graduates at Toshi University for a College of Business and if it is not provided, these students will go to other universities, and, (4) there is a demand from the 
parents who think the program will provide greater job opportunities for their children after graduation.

During the three years of planning, before the official announcement by the President in the Spring of 1999, only a small group of faculty had actually been involved in the process to establish the new college. According to the survey results (Table 31 ), over $50 \%$ of faculty respondents either had no opinion or gave no answer to the questions about which groups were most instrumental in the development and implementation of the new college. Many of these respondents provided additional comments on their survey, explaining that they did not have sufficient knowledge to answer the question because they had not been involved in the establishment of the new college. Of those who did give an opinion, the President was cited as being the most influential, both in the development and implementation stages of the decision-making. The Board of Trustees was considered to be the next most influential group in both areas. The Faculty Council was considered to be the third most instrumental group in terms of its role in the development stage of the decision to establish the new college. Further, faculty respondents reported that the Ministry of Education was probably the least instrumental, both in the development and implementation of the decision-making process. Among the administrators who were interviewed, everyone indicated that the President was the most influential. Some of the administrators mentioned the role of the deans and some of the faculty who were already teaching business courses in the College of Arts and Education. The Ministry of Education was also considered by many to be influential due to the 
recent reforms that encourage universities to establish new programs that have a distinctive character.

\section{Table 31}

All Faculty Respondents' Opinions about which Groups were Most Instrumental in the Development and Implementation of the New College

\begin{tabular}{lccccc}
\hline \multicolumn{1}{c}{ Group } & $\begin{array}{c}\text { Develop- } \\
\text { ment }\end{array}$ & $\begin{array}{c}\text { Implem- } \\
\text { entation }\end{array}$ & Both & $\begin{array}{c}\text { No } \\
\text { Opinion }\end{array}$ & $\begin{array}{c}\text { No } \\
\text { Answer }\end{array}$ \\
\hline Ministry of Education & $5(08.19)$ & $6(09.83)$ & & $50(81.96)$ & 35 \\
$\mathrm{~N}=61$ & & & & & \\
Board of Trustees & $13(17.80)$ & $13(17.80)$ & $5(06.84)$ & $42(57.53)$ & 23 \\
$\mathrm{~N}=73$ & & & & & \\
President N=81 & $17(20.98)$ & $21(25.92)$ & $9(11.11)$ & $34(41.97)$ & 15 \\
Deans' Council & $9(13.23)$ & $12(17.64)$ & & $47(69.11)$ & 28 \\
$\mathrm{~N}=68$ & & & & & \\
Faculty Council & $12(18.46)$ & $7(10.76)$ & $1(01.53)$ & $45(69.23)$ & 31 \\
$\mathrm{~N}=65$ & & & & & \\
\hline
\end{tabular}

The survey results (Tables 32-35) provide evidence that students, parents and alumni had been the least consulted about the decision to establish a new school. The survey respondents indicated that faculty had been the most involved with $27 \%$ reporting that this group had been adequately consulted, compared to less than $10 \%$ who indicated that any one of the other three groups had been adequately consulted. One of the survey respondents from the College of Arts and Education commented on his survey that "only a few faculty had been involved in the decision-making process, mainly from the College of Arts and Education." According to one of the administrators in the Office of Academic Affairs who was coordinating the approval process with the Ministry of 
Education, Toshi University was actually prohibited from discussing the decision to establish the new school with students and members from the outside community until the approval was obtained. However, as part of the proposal, Toshi University was required to survey the groups that would be most affected by the establishment of the new school. The results of the survey were reported in December 1997 and included responses from 3071 parents of children enrolled in the Toshi K-12 school (74.7\% response), 1413 students enrolled in the Toshi Secondary School (91.0\% response), and 2452 alumni (23.2\% response). Business firms were also surveyed. The survey results indicated a high approval rating from all of these groups for the establishment of a College of Business at Toshi University.

\section{Table 32}

Faculty Respondents' Opinions about whether or not Faculty were

Adequately Consulted about the Establishment of the New College

\begin{tabular}{lcccc}
\hline & $\begin{array}{c}\text { Adequately } \\
\text { Consulted }\end{array}$ & $\begin{array}{c}\text { Not Adequately } \\
\text { Consulted }\end{array}$ & $\begin{array}{c}\text { No } \\
\text { Opinion }\end{array}$ & $\begin{array}{c}\text { No } \\
\text { Answer }\end{array}$ \\
\hline Arts \& Education N=38 & $11(28.94)$ & $17(44.73)$ & $10(26.31)$ & 5 \\
Agriculture $\mathrm{N}=22$ & $7(31.81)$ & $11(50.00)$ & $4(18.18)$ & 2 \\
Engineering $\mathrm{N}=28$ & $6(21.42)$ & $13(46.42)$ & $9(32.14)$ & 1 \\
University-wide $\mathrm{N}=88$ & $24(27.27)$ & $41(46.59)$ & $23(26.13)$ & 8 \\
\hline
\end{tabular}


Table 33

Faculty Respondents' Opinions about whether or not Students were Adequately Consulted about the Establishment of the New College

\begin{tabular}{lcccc}
\hline & $\begin{array}{c}\text { Adequately } \\
\text { Consulted }\end{array}$ & $\begin{array}{c}\text { Not Adequately } \\
\text { Consulted }\end{array}$ & $\begin{array}{c}\text { No } \\
\text { Opinion }\end{array}$ & $\begin{array}{c}\text { No } \\
\text { Answer }\end{array}$ \\
\hline Arts \& Education $\mathrm{N}=38$ & $1(02.63)$ & $23(60.52)$ & $14(36.84)$ & 5 \\
Agriculture $\mathrm{N}=22$ & $2(09.09)$ & $7(31.81)$ & $13(59.09)$ & 2 \\
Engineering $\mathrm{N}=28$ & $4(14.28)$ & $12(42.85)$ & $12(42.85)$ & 1 \\
University-wide $\mathrm{N}=88$ & $7(07.95)$ & $42(47.72)$ & $39(44.31)$ & 8 \\
\hline
\end{tabular}

Table 34

Faculty Respondents' Opinions about whether or not Alumni were Adequately Consulted about the Establishment of the New College

\begin{tabular}{lcccc}
\hline & $\begin{array}{c}\text { Adequately } \\
\text { Consulted }\end{array}$ & $\begin{array}{c}\text { Not Adequately } \\
\text { Consulted }\end{array}$ & $\begin{array}{c}\text { No } \\
\text { Opinion }\end{array}$ & $\begin{array}{c}\text { No } \\
\text { Answer }\end{array}$ \\
\hline Arts \& Education $\mathrm{N}=38$ & & $21(55.26)$ & $17(44.73)$ & 5 \\
Agriculture $\mathrm{N}=22$ & $2(09.09)$ & $10(45.45)$ & $10(45.45)$ & 2 \\
Engineering $\mathrm{N}=28$ & $2(07.14)$ & $12(42.85)$ & $14(50.00)$ & 1 \\
University-wide $\mathrm{N}=88$ & $4(04.54)$ & $43(48.86)$ & $41(46.59)$ & 8 \\
\hline
\end{tabular}

Table 35

Faculty Respondents' Opinions about whether or not Students' Parents were Adequately Consulted about the Establishment of the New College

\begin{tabular}{lcccc}
\hline & $\begin{array}{c}\text { Adequately } \\
\text { Consulted }\end{array}$ & $\begin{array}{c}\text { Not Adequately } \\
\text { Consulted }\end{array}$ & $\begin{array}{c}\text { No } \\
\text { Opinion }\end{array}$ & $\begin{array}{c}\text { No } \\
\text { Answer }\end{array}$ \\
\hline Arts \& Education $\mathrm{N}=38$ & & $20(52.63)$ & $18(47.36)$ & 5 \\
Agriculture $\mathrm{N}=22$ & $3(13.63)$ & $10(45.45)$ & $9(40.90)$ & 2 \\
Engineering $\mathrm{N}=28$ & $2(07.14)$ & $12(42.85)$ & $14(50.00)$ & 1 \\
University-wide $\mathrm{N}=88$ & $5(05.68)$ & $42(47.72)$ & $41(46.59)$ & 8 \\
\hline
\end{tabular}




\section{Discussion of the Research Questions}

In the following section, the research questions will be addressed. Before proceeding with this discussion, it is necessary to provide a summary of which governance bodies played the most significant role in the decision to establish a College of Business. The major academic governance bodies involved in the decision were the President, the Ministry of Education, the Future Planning Committee, Ad Hoc committees composed of faculty that reported directly to the President, and the Faculty Councils. Surprisingly, the Dean's Council was never mentioned as playing a major role in the decision, although the deans were involved as members of the Faculty Council, the Future Planning Committee, and the Ad Hoc committees. External groups, namely parents and business firms, also played a minor role in the academic governance process. The major administrative governance bodies involved in the decision were the President, the Board of Trustees, the Ministry of Education, the Office of Academic Affairs, and Ad Hoc committees composed of administrators that reported directly to the President. The major governance bodies involved in the external affairs aspects of the decision were the President, the Board of Trustees, and the Ministry of Education.

\section{Research Question \#1}

Describe and analyze the bureaucratic, collegial, political and other governance patterns at Toshi University as reflected through past major decisions on the functions of academic programs and instruction and the implications of the new reforms for those patterns. 
The research findings demonstrate the following patterns of governance and authority structures before and after the 1998 reforms on the functions of academic programs and instruction: (1) the bureaucratic model was reflected in the Ministry of Education and its approval authority over the academic programs for the College of Business; (2) the collegial model was seen in the participation by the faculty on the various committees that developed the academic programs and policies for the new college; (3) the political model was reflected in the role of the external interest groups, namely the parents and business firms, and their role in deciding what type of academic programs would be established; (4) personal authority structures were reflected in the President who provided extensive direction in the development and implementation of the academic program. The 1998 University Council reforms have implications for (1), (2), (3), and (4). The research findings did not find any evidence of professional or trustee authority structures on the decision to establish the College of Business before or after 1998 on the function of academic programs and instruction.

First of all, the bureaucratic patterns have been weakened by the reform, which has begun to give individual universities more control over their academic programs. At the same time, signs indicate that these bureaucratic patterns will not weaken to the point that they will disappear all together. The decision to establish the College of Business was made during this period of reduced Ministry-control over the curriculum. As a result, Toshi University was able to include many courses in the College of Business curriculum that are unique and distinctive to its school philosophy that it might not have been able to include 
before 1991. On the other hand, while the 1998 reforms continue to encourage the increased autonomy of individual universities over their academic governance, schools are also being asked to toughen their academic standards. Toshi University's adoption of a high GPA requirement for its College of Business curriculum, although voluntary, was largely a response to the government's call for tougher academic standards. These tougher standards were not part of the original recommendations that the Future Planning Committee made to the President in 1996. The decision to include a high GPA requirement was made after 1998 in response to the new reforms. In fact, one of the concerns that many faculty and administrators had with the proposal was that the high GPA requirement would make it more difficult to recruit a sufficient number of students. The current trend in Japan is for schools to lower their standards in order to continue admitting the same number of students. Most scholars agree that the Ministry of Education's bureaucratic authority will be weakened as a result of the 1998 reforms as it continues to relax its regulations over the academic affairs of the individual universities. On the other hand, there is also a possibility that the current calls for toughening standards may elevate bureaucratic patterns as reflected in increased regulations because, unlike Toshi University, schools do not voluntarily raise their standards as the Ministry had hoped.

Secondly, the collegial patterns have been strengthened by the reform, which seeks to give more autonomy to the individual universities over their academic programs and instruction. The design of the academic programs of the 
College of Business were primarily developed by faculty who first began working together during the Future Planning Committee sessions in 1995 and 1996, and later, in Ad Hoc committees that reported directly to the President. However, the collegial participation by the faculty on this decision was limited. The survey results demonstrate (as seen in Table 30) no widespread faculty involvement in the decision to establish a College of Business as indicated by the large number of respondents (66\%) who indicated "Don't Know" on this item of the survey. Moreover, the majority of faculty members at Toshi University do not participate in the Future Planning Committee, which was where the decision originated; and while they do all participate in Faculty Councils, only the Faculty Council in the Department of English and American Literature was involved in the decision. Ad Hoc faculty committees were also involved in the decision, but these committees were only composed of one or two faculty from each department and college. In fact, not until the proposal had been fully developed in January 1999 was it finally presented to the various Faculty Councils. However, it is likely that faculty participation in governance will increase in the future, along with the increased collegial patterns of governance represented by the Future Planning Committee and Faculty Councils. The 1998 University Council reforms seek to give individual universities more autonomy over their academic programs and instruction and in exchange universities are expected to become more accountable to the public and engage in self-assessment. This reform will especially be true for the College of Business, which will be required by the Ministry of Education to undergo an external assessment as a new college 
before it will be allowed to expand. The reforms also encourage faculty to participate on these assessment committees, which will increase opportunities for future collegial patterns on the governance processes.

The political patterns of governance on the functions of academic programs and instruction have been strengthened by the reform, which empowers external interest groups through its recommendations for external and internal assessment and public disclosure. The decision to establish a College of Business, opposed to a College of Education, or College of Fine Arts, was partly the result of market forces, a reaction to the demands of parents, students, and business firms. The reform has basically served to empower these public interest groups by forcing universities to factor public opinion into its decisionmaking. This trend can be traced back to the revised University Establishment Standards in 1991 that require universities to survey the public before establishing a new college or department. External interest groups are expected to continue having more and more influence over the decision-making through political influence. Toshi University may possibly be forced to disclose the results of its assessments, as well as the results from third-party assessments, to the public. In fact, this requirement may be a prerequisite for expanding the College of Business in the future. The knowledge from the published reports of university assessments will give the external groups even more power than they have now.

Finally, the personal authority structure has been strengthened by the reform, which recommends a strong president at the center of the decision- 
making. This authority structure was prominent in the decision-making over academic programs and instruction related to the establishment of the College of Business, although at the same time, bureaucratic, collegial and political patterns of governance were all present as well. The President's involvement in this decision-making process is perhaps best illustrated by another decision that involved academic programs and instruction. One of his first objectives as a new president at Toshi University five years ago, was to make university-wide curriculum revisions. As the President's comments suggest, the personal authority structure was just as evident in the decision-making that occurred five years ago as it was in the decision to establish the College of Business:

Before I became President, we had a one-year semester, which began in April. Now we have a Spring semester which begins in April and ends in September and a Fall semester which begins in October and ends in March. This change was the result of some Ministry of Education-initiated reforms in the early 90s. I personally initiated this reform at our university after I became President and we were one of the forerunners to adopt the semester system in Japan. I had actually tried to initiate this change fifteen years ago before I became president, when I was a faculty member and division head at the University, and people at the time called me crazy. I got a lot of resistance with this idea from other faculty who could not imagine giving two grade reports each year. After I became President, there was no longer the resistance that I experienced before, probably because by that time internationalization was more trendy and other 
schools were beginning to adopt two semester systems. (Personal

Communications, June 1999)

With the 1998 University Council reforms, the personal authority structure has been reinforced and made stronger by the reforms that recommend a stronger president at the center of decision-making. This structure will continue to serve as the primary pattern of academic governance at Toshi University and will have a major impact on the future operation and expansion of the College of Business.

\section{Research Question \#2}

Describe and analyze the bureaucratic, collegial, political and other governance patterns at Toshi University as reflected through past major decisions on functions of faculty affairs (promotion, tenure, etc.) and the implications of the new reforms for those patterns.

Faculty affairs encompasses all of those areas of academic governance related to the performance of the faculty, including their teaching, research, service and governance roles. Issues related to promotion, benefits, tenure, academic freedom and the control faculty possess over their various performance roles are all different aspects of the faculty affairs. The research findings demonstrate the following patterns of governance and authority structures before and after the 1998 reforms on the functions of faculty affairs: (1) the collegial model was reflected in the Future Planning Committee and the role it played in the decision to establish the College of Business; (2) professional authority structures were reflected in the College of Arts and Education faculty 
who opposed the decision; (3) personal authority structures were reflected in the President's role in determining which faculty members would be involved in the process to establish the new school. The 1998 University Council reforms do not have any implications for (3), but they do have implications for (1) and (2). The research findings did not find any evidence of bureaucratic or political patterns of governance or trustee authority structures on the decision to establish the College of Business before or after 1998 on the function of faculty affairs.

First, the collegial model has been strengthened by the reform, which encourages involvement of the faculty in the future assessment process of the College of Business. Secondly, the professional authority structure has been weakened by the new reform. As mentioned at the beginning of this chapter, the weakening of the professional authority structure can be primarily attributed to the President who initiated a change soon after becoming president that required departments to standardize their specialized curriculum based on the content of the program. Before that time, the requirements for the major areas of study were much less standardized and were more dependent on who taught the courses, rather than what was being taught. It appears that this professional authority structure was further weakened by the establishment of the College of Business. According to one of the faculty members in the College of Arts and Education who was familiar with the controversy, some faculty members opposed the decision based on philosophical reasons. These reasons are revealed in the 1999 Toshi University Student Bulletin, which states that the business courses were housed in the Department of English and American 
Literature because the intention of the program was to help its students develop an international view on business management. By providing a curriculum that promotes a deep understanding of English-speaking cultures through the study of the English language and literature. Another faculty member in the Department of English and American Literature, who serves on a curriculum committee for the new College of Business, described the reaction of some of the faculty in his department to the decision:

I was on the front line dealing with the faculty. Some of them said that the curriculum did not have enough new ideas and others said it needed to be more traditional. Many of the faculty currently teaching business courses were opposed because they will have to teach different courses. Japanese professors tend to teach like their professors and they are very traditional. In my case, I was educated in the United States and many of my ideas came from the business curriculum models found in the United States. (Personal Communicatons, June 1999)

As one might imagine, the establishment of new colleges or departments on a college campus is likely to meet with some resistance at any university. Tadao Ishikawa, President of Keio University, who established two new colleges at his private university in 1990, writes in Green's (1997) book, Transforming Higher Education: Views from Leaders Around the World:

Keio is an old, large university with tradition and a history of success. In this context, it is not easy to establish new faculty. Existing faculties are naturally interested in maintaining and developing their own research 
agenda. They react negatively to the emergence of a new faculty, fearing infringement upon what is perceived to be vested rights and a decline in budget allocations... The main reason to establish these new faculties was to respond to the needs of the future. At the same time, I also hoped the new faculties would provide a strong competitive challenge to the traditional faculties, which were resistant to change because of past success and a tendency to be conservative. I also sought to encourage internal change in the existing faculties. (p. 305)

The opposition from some of the faculty in the Department of English and American Literature at Toshi University reflects a professional authority structure that is based on philosophical goals and rewards superseding or opposing those of their institution. This type of authority structure has grown weaker after the 1998 reforms, and it will probably continue to grow even weaker as the demands of the environment, namely the reforms and the public, become the major influence on how university resources are allocated.

\section{Research Question \#3}

Describe and analyze the bureaucratic, collegial, political and other governance patterns at Toshi University as reflected through past major decisions on the functions of financial affairs and other managerial activities and the implications of the new reforms for those patterns.

The research findings demonstrate the following patterns of governance and authority structures before and after the 1998 reforms on the functions of financial affairs: (1) bureaucratic patterns of governance are reflected in the 
Ministry of Education's approval authority over the budget and enrollment of the new school; (2) bureaucratic patterns of governance can also be applied to the administrative staff in the Office of Academic Affairs who were responsible for coordinating the application for approval from the Ministry, including the budget, staffing and facilities; (3) the political model is reflected in the faculty who either supported or opposed the decision of how university resources were allocated on the basis of the special program requirements of the new school; (4) tustee authority structures were reflected in the Board of Trustees who made the final decisions on the budgetary matters regarding the establishment of the new school; and (5) personal authority structures were reflected in the President who guided the process from beginning to end and was financially motivated due to his ownership of the university. The 1998 University Council reforms have no implications for any of the above governance patterns and authority structures on the function of financial affairs. The research findings did not find any evidence of collegial patterns of governance or professional authority structures on the decision to establish the College of Business before or after 1998 on the function of financial affairs.

During the decision to establish the College of Business, the Office of Academic Affairs coordinated the approval process with the Ministry of Education. Just as the bureaucratic model applies to the Ministry of Education, it also applies to this office and the other administrative offices at Toshi University, such as the Office of Admissions, Office of Personnel and the Office of Bursar. The offices function in very clear hierarchical patterns, where each 
staff member reports to one superordinate, who in turn reports to a more senior superordinate. In the process to establish the new school, the Director of Academic Affairs reported directly to the President because of his dean-level status. On an official level, only deans and trustees report directly to the President:

I communicate through the trustee members and the deans. I rarely interact with the deans on an official level outside of the Dean's Council meetings, unless there is an emergency or one of the deans makes the initiative to contact me directly. I rarely interact with the department chairs, faculty or staff on an official level, although I frequently bump into these people on the campus and have informal communication. It is possible for anyone to make an appointment with me to discuss official business, but I rarely initiate the communication myself. Every year, on the first day of school in April, I give a state of the university address to all of the campus faculty and staff. Occasionally, deans will initiate a meeting with me to discuss matters or on-going projects which originate from the department or school level, and occasionally I will initiate the meeting. (Personal Communications, June 1999)

Another example of the bureaucratic patterns found in the administrative areas were included in the comments by the Director of Personnel at Toshi University:

I interact with the President to determine what the priorities of the university are and how the personnel resources are used to accomplish 
the goals of the university. The goals are outlined in the President's state of the university address, which he gives in April. (Personal Communications, June 1999)

In addition to the bureaucratic model, the political model was also evident in the College of Business decision on the function of financial affairs and is best reflected in the faculty who either supported or opposed the decision of how university resources were allocated. The faculty members in the Department of English and American Literature who opposed the decision did not have sufficient power to promote their interests above the interests of the faculty who supported the new College of Business. Many faculty members who opposed the decision were reacting to the change in how university resources would be allocated in the future. As one faculty member commented in the College of Engineering:

The College of Engineering is concerned about the establishment of this new College of Business and its impact on the College of Engineering. There will certainly be an impact on the budget of our University and how future resources will be allocated. I'm sure it concerns some of the faculty in the College of Engineering. (Personal Communications, June 1999)

The role of the Board of Trustees in the decision to establish the new school was primarily deciding on the budgetary matters and representing the decision to the public and Ministry of Education as necessary. The trustee authority structure was represented by the seven members of the Board of Trustees who represent the school corporation. While the trustee authority 
structure was certainly present in the decision to establish the new school, it was present to a much lesser extent than the personal authority of the President, or even the ad hoc committees that reported directly to the President. Of the three full-time trustees (not including the Chairman), only two were directly involved with the decision on a daily basis. Since one of the trustees represented the K12 schools of Toshi Academy, his involvement was unnecessary. However, the other two full-time trustees were directly involved in the planning and implementation of the decision. The one trustee who oversees the administration worked closely with the Director of Academic Affairs. The trustee who oversees the academic affairs of the university worked closely with the Dean of the College of Arts and Education and the faculty members on the committees coordinating the development of the academic programs.

While these two trustees and the President discussed the decision regularly, in both formal and informal meetings, it appears that the ad hoc committees that reported directly to the President, and the President himself, were more instrumental in the decision-making process. Moreover, the part-time trustees had very limited involvement in the process, if any involvement at all. The researcher met with one of the part-time trustees informally; he was knowledgeable about the College of Business development and very supportive of the project, but gave no indication that he was participating directly in the decision-making process. Therefore, the researcher concludes that although some of the individual members of the Board of Trustees were actively involved in the process through their membership on one of the committees or through 
their personal interaction with the President, the trustee authority represented by this body of governance was quite weak. Moreover, nothing indicates that this authority structure will be weakened or strengthened in the future as a result of the reform.

\section{Research Question \#4}

Describe and analyze the bureaucratic, collegial, political and other governance patterns at Toshi University as reflected through past major decisions on functions of external relationships with key parts of the environment, including business and industry and alumni and the implications of the new reforms for those patterns.

The research findings demonstrate the following patterns of governance and authority structures before and after the 1998 reforms on the functions of external relationships with key parts of the environment: (1) the bureaucratic model was reflected in the Ministry of Education that required Toshi University to survey the parents, alumni, and business firms as part of its application process for establishing the new school; (2) the political model is reflected in the Toshi University faculty and administrators who are seeking to establish cooperative research agreements and partnerships with industry as one of the missions of the new school; (3) personal authority and trustee structures were reflected in the President and Board of Trustees who are the official representatives of the school to the public. The 1998 University Council reforms have implications for (1), (2), and (3). 
First, the bureaucratic patterns may be strengthened by the reform, which seeks to make universities accountable to the public which in itself will invite other kinds of regulations from the government. Secondly, the political patterns of governance have been strengthened by the reform, which promotes expanding linkages between the university and the community, especially with private industry, as well as partnerships between public and private universities. Finally, the personal authority and trustee structures have been strengthened by the reform, which recommends a strong president at the center of decisionmaking. The research findings did not find any evidence of collegial patterns of governance or professional authority structures on the decision to establish the College of Business before or after 1998 on the function of external affairs.

The major governance bodies involved in the decision on the function of external affairs are the Ministry of Education, the President, and the Board of Trustees. Since 1998, the Ministry of Education has been requiring universities to become more accountable to the public and this is perhaps one of the clearest examples of bureaucratic patterns over the function of external affairs. The Ministry of Education's requirement that Toshi University survey the parents, alumni, and business firms as part of its application process for establishing the new school is only one example of this increased accountability. In order for the College of Business to expand, Toshi University may have to carry out internal and external assessments and disclose the results of these assessments to the public. Thus, it appears that these bureaucratic patterns may be strengthened by the reform. As mentioned in Chapter 4, Toshi University is already conducting 
assessments of the university and some of its findings are published in reports that are available to prospective students and their parents. Each college and department at Toshi University also publishes information about its programs and research projects on its school website.

The political model is reflected in the Toshi University faculty and administrators who are seeking to establish cooperative research agreements and partnerships with industry. The prominent bureaucratic role the Ministry has played in directing universities to become more interactive with their external groups does not adequately explain the increased responsiveness of universities to the outside communities. It must also be noted here that these faculty and administrators must interact with the public through the President and Board of Trustees who are the official representatives of the new school to the public. The idea of universities cooperating with business and industry is relatively new in Japan, but has recently become more accepted as demonstrated by the widespread agreement by faculty members at Toshi University that research should address the needs of the community and business. According to the results of the survey (as shown in Table 24), about $73 \%$ of the faculty respondents agreed that faculty research should be more sensitive to community and business needs, and very few faculty disagreed with this trend.

Motivated primarily to compete more effectively for the dwindling number of students, Toshi University is seeking partnerships and consortiums with other universities to make the College of Business more attractive to students. For example, the curriculum of the new school will allow students to transfer credit up 
to the maximum allowed by the Ministry of Education, and administrators are searching for domestic and foreign universities with which to develop exchange programs and articulation agreements. Like most universities in Japan, until only recently, Toshi University had very little official communication with the outside environment, but government reforms are encouraging more openness and interaction with the public.

\section{Research Question \#5}

Describe and analyze the bureaucratic, collegial, political and other governance patterns at Toshi University as reflected through past major decisions on other important functions and the implications of the new reforms for those patterns.

No other functions were reported in the case study findings.

\section{Japanese Characteristics of Governance}

Throughout the above discussion, western-based models of governance were described and analyzed as they related to the decision to establish the College of Business at Toshi University. None of these models, by themselves, adequately explain the governance patterns as reflected in the majority of the decisions, whether on the functions of academic programs and instruction, faculty affairs, financial affairs or the relationship with key parts of the environment. The primary models of governance at Toshi University appear to be more of a mixture of these Western-based models and Japanese cultural patterns. Of all of the models described thus far, the personal authority structure 
exhibited by the President was perhaps the most pervasive, second only to the bureaucratic patterns of the Ministry of Education. In fact, the personal authority structure was present to such a high degree that it subverts the other patterns, resulting in mixed models of governance, usually combining personal authority with the bureaucratic, collegial, or political models. The mixed governance patterns follow the Western patterns, but they only go so far in explaining the models of governance found at Japanese institutions. Some of the governance models at Toshi University diverge from the Western-based models when they are embodied with one or more of the Japanese cultural values, such as consensus, harmony and group solidarity.

Japanese Personal Authority. Absolute authority does not characterize the personal authority patterns at Toshi University, perhaps because the other models have the effect of diluting or softening the personal authority patterns. As a result, the President is never forceful and domineering. Moreover, this is not the typical approach to leadership in Japan where leaders are expected to be sensitive to the feelings of others. According to Reischauer (1988), leaders in Japan are

... shown by the warmth of their personalities and the admiration and confidence they inspire rather than by the sharpness of their views or the vigor of their decisions. What the American might consider as desirably strong leadership causes suspicion and resentment in Japan. Consensus through prolonged consultation is the norm. The purported boss more often seems to be just the chairman of the committee. (p. 157) 
One reason for such a strong personal authority at Toshi University is due to the President's ownership of the school corporation. Yet, not all of the President's ideas are unanimously accepted. While the President of Toshi University is considered by the other faculty and administrators on his campus to be a visionary leader, he is also a young president, and because of his youth, and to a lesser extent his Western education, he sometimes encounters resistance to his ideas by some of the faculty. According to one faculty member,

The President is powerful and he is a progressive thinker, but he has much pressure from the older generation of faculty and administrators who may not be as progressive in their thinking. (Personal Communications, June 1999)

As a young president, he must face cultural barriers related to the roles that Japanese consider to be appropriate to one's status and position, which is usually determined by age. As Reischauer (1988) states,

Unlike the American propensity for the elderly person to try to act young or the company president to be one of the boys, the Japanese try to live up to their status. In earlier times, the concept of taking one's proper station in life had to do with the unchanging hereditary status, but now it means to act one's age and one's position as one moves up in life. (Reischauer, $p$. 155)

As the survey results indicate, the opposition to the President's plans for change is limited to about $20 \%$ of the faculty. These faculty members are the more senior members of the faculty who are strongly oriented to the traditions of a 
chair system. Most national and public universities and many private universities in Japan, incorporate a strong chair system. According to Clark (1983), this system is often "mixed with certain Japanese characteristics of small-group loyalty and cohesiveness." The small group of senior faculty who often make up the chair system are more powerful than a single individual faculty member or even the department chairperson. For this reason, as the expression goes, the chair of a department is not a "chair," but a sofa because it seats many. Toshi University does not have a chair system, but the professional authority structure that is present at Toshi shares some characteristics in common with this system, such as the small-group loyalty. Moreover, like the chair system, the professional authority structure presents a challenge for any president who is trying to achieve centralized control over their institution.

The President also derives much of his power from charisma. The identity he projects is one of strength, intelligence and knowledge, and he consistently manages to command the respect of his faculty and staff to accomplish his objectives. Another source of his charisma is his status as a descendent of the founder of Toshi Academy. As a descendent, he derives some of his power from what Lebra (1991) refers to as "ancestral charisma." According to Lebra, Japan is a country of ancestor-oriented faith and ritual and, in such a context, "ancestors may appear as resources at the disposal of a descendent to build up and sustain a desirable identity of his/her own."

Personal Authority and the Bureaucratic Model. One reason for such a strong personal authority at Toshi University is due to the President's 
ownership of the school corporation. As Chairman of the Board of Trustees, the President sits atop the corporate hierarchy and holds the final decision-making authority over all academic and administrative affairs of his university. In this way, the personal authority is combined with the bureaucratic model, as reflected in the President's State of the University address that he delivers each year in April. This speech will contain many of his goals and objectives that become the blueprints for developing new agendas for change in the academic programs and the administrative processes of the university for the coming year. The mixture of bureaucratic and personal authority models was evident in the College of Business decision, especially in decisions about the functions of academic programs and instruction. For example, during the process of establishing the College of Business, the various committees would often spend time reviewing the President's prior communications and speeches in order to guide the development of the academic programs.

At Toshi University, despite occasional opposition to the President's agenda, there is no evidence of an organized anarchy, such as that described by Cohen and March (1974) in their book, Leadership and Ambiguity. The personal authority at that institution combined with the bureaucratic model is sufficiently strong to guarantee a central coordination over both the academic and administrative decision-making. The successful implementation of the decision to establish a new school by the President, despite the opposition by some of the faculty in the College of Arts and Education, illustrate this centralized control. 
Personal Authority and the Collegial Model. The President at Toshi University has been successful in combining the personal authority with the collegial model. This combination has resulted in a very effective style of management that is used quite frequently by the President:

... faculty come up with various ideas and they are very frank in their opinion and I sometimes include these ideas in my proposals. In these cases, it may appear that the initiative is coming from me; however, it actually came from a faculty member. Sometimes I have an idea for an initiative, something I might have gathered from a trip abroad or something I read. I will call up a Dean and the idea will be discussed in his division and at the departmental level and may serve as a basis for future proposals. (Personal Communications, June 1999)

When the collegial model is observed at Toshi University, it is usually combined with the Japanese values of consensus and harmony. For example, the Faculty Council and Future Planning Committee meetings are primarily collegial and reflect the notion of peer privileges and consent of the governed; however, these meetings are also characterized by consensus-style decisionmaking in which an elite group of leaders (usually the most senior in age and rank), not usually a single individual, shapes the decision making using what Japanese refer to as nemawashi. According to Christopher (1983),

Nemawashi involves a cautious feeling-out of all the people legitimately concerned with an issue, a highly tentative process in which no firm 
stands are openly taken and argument is implicit rather than explicit. (Christopher, p. 54)

The term, nemawashi, is often used among those who grow bonsai plants. It literally describes the action of cutting around the roots of a plant before it is transplanted. The careful pruning and positioning of the roots will determine the future growth of the plant. An analogy can be made here with the College of Business at Toshi University that will illustrate the way nemawahi was used in an attempt to build consensus for the decision. First of all, nothing indicates that the decision to establish the College of Business was made autocratically by the President. To use such a top-down approach would be analogous to yanking out a plant by its stem. Instead, nemawashi was used, which included conducting many wide informal discussions involving the concerned subordinates, mainly the faculty who were being affected in the College of Arts and Education. These faculty members were the roots, which would need to be carefully tended by the President and a small group of deans, administrators and senior faculty members. The President made a great effort to fully familiarize the affected faculty members with the decision in advance, instead of making the decision without any warning. The goal of the process was to achieve consensus, although the survey results suggest that consensus may not have been completely reached as the majority of respondents in the College of Arts and Education indicated that the attitudes of faculty toward recent changes in the curriculum have been mostly negative. 
Another aspect of this mixed collegial model in Japan is seen in the ways the leaders, such as the dean or the chair of the committee, might work around obstacles to achieve harmony. Such activity is considered the mark of leadership in Japan. As Reischauer (1988) explains,

The key Japanese value is harmony, which they seek to achieve by a subtle process of mutual understanding, almost by intuition, rather than by a sharp analysis of conflicting views or by clear-cut decisions, whether made by one-man dictates or majority votes. (p. 136)

Harmony was a key concern of one of the committees involved in the planning of the College of Business. After approval of the application to establish the new school, one of the main functions of the Education Committee to Discuss Special Topics Such as the Establishment of a New College was to address the impact the new college would have on other parts of the University. Specifically, this committee was concerned about the impact of the new school on the College of Arts and Education and how to resolve the potential problems raised in the Faculty Council meetings in the Department of English and American Literature. With the departure of some of their faculty, that department would have to modify its curriculum and would face the problem of how to handle the faculty who were presently teaching the business courses in addition to non-business courses in that department. The "subtle processes of mutual understanding" described by Reischauer was certainly used extensively by the elite group of senior faculty and administrators on the committee who dealt with these various issues, but more importantly worked toward the desired harmony in the relationships. 
Personal Authority and the Political Model. Another of these mixed models combines the personal authority structure with the political model as reflected in the President and his relationship with the deans and faculty. According to the President, his relationship with the dean will determine how effective that dean will be in getting their proposals implemented:

The various committee meetings, such as the committees that meet at the Future Planning Meeting, are a source for new ideas and new proposals for change; however, the actual implementation is different. Every school, division and department has ideas for changes they would like to make, but they do not all get initiated equally. Much depends on my personal relationship with the dean. If I can speak frankly with the dean, instead of on a formal level, there is more likelihood that the proposals will be initiated. If my relationship with the dean is on a formal level as a supervisor-employee relationship, rather than a familiar relationship, there is not much chance of changes being implemented unless it's a government mandate of some kind. For example, the Chair of the Department of Education is a personal friend. He is around the same age and we went to school together and we can talk very frankly. For this reason, we can see a lot of change happening in his department. The College of Agriculture is the same way. The Dean of the College of Engineering, on the other hand, is much older than me and our relationship is much more formal; therefore, very little change is initiated in 
this school unless it comes through bureaucratic channels. (Personal Communications, June 1999)

In the case of the decision to establish the College of Business, clearly the key players in the planning and implementation were those faculty and deans who had a similar personal background to the president, including their age, education and philosophy of teaching and learning. Also, note that the College of Arts and Education faculty were more involved in the planning process of the new school than the faculty in the College of Engineering, even though both colleges have business-related courses and faculty with background in this area. The President's personal relationship with the Dean of the College of Arts and Education was obviously an important factor in the College of Business decision. The mixed political and personal authority model was one of the prevailing patterns of governance in deciding which colleges, departments, and groups of faculty would be included in the process and benefit from the inclusion.

$\underline{\text { Trustee Authority and Japanese Group Values. Another mixed model }}$ that is evident at Toshi University is trustee authority combined with Japanese group values. In addition to their role in the governance over the financial affairs, the trustee members might also be described as "go-betweens" with external bodies and the institution. The function of a "go-between" has a long history in Japan, as Reischauer (1988) explains:

To avoid confrontation and maintain group solidarity, the Japanese make wide use of go-betweens. In delicate transactions, a neutral person scouts out the views of the two sides and finds ways around obstacles or 
else terminates the negotiations without the danger of an open confrontation or loss of face on either side. (pp. 137-138)

As already mentioned, the various external groups, such as the parents, alumni and businesses, played a very important role in the process of establishing the College of Business as the University surveyed these various publics, as was required by the Ministry of Education. Another example of Toshi University interaction with the public was when it sought out key members of the business community in order to secure partnerships with companies and business leaders. This interaction was not a requirement of the Ministry of Education, but was an attempt to build support for the school. The part-time trustees were often instrumental in serving as "go-between" with these companies and business leaders. Given the Japanese tendencies to avoid confrontation and maintain group solidarity, this course was a much more effective method than the President or other university officials directly approaching these companies and business leaders for support.

Duality of Authority. Another aspect of governance that is perhaps not addressed in any of the Western models is the duality of authority. The Japanese university contains many examples of the separation of authority and power. For example, at many universities in Japan, presidents do not have the influence of their Western counterparts, although from an official standpoint they occupy the top position at the University. At these universities, decisions are made in the Faculty Council meetings through a process of consensus-building, and the President is merely a figurehead. This situation is a classic illustration of 
the difference between omote and ura. Omote is literally the surface or front of an object and ura its back or reverse side. Tasker (1987) provides a more abstract duality to the terms in the following description:

Omote is the official, public aspect of a person, event or institution, and ura its unofficial or private aspect. Thus, an omote signboard means a pretext or a figurehead, while '"to see the ura of a man's heart" is to understand his true feelings. Almost every sphere of Japanese society has its omote and its ura: as if by law of nature, phenomena divide into distinct but mutually-dependent realities. (p. 67)

The Board of Trustees at Toshi University is an example of this duality of authority. The Constitution of Toshi University describes the authority of this body of governance as the supreme authority over all academic and administrative decisions. This is the omote, or official version. The ura, or unofficial reality, is that it is actually one of the weakest bodies of governance, and its power is significantly less than that of the President. In fact, the part-time trustee members are more or less figureheads with almost no power at all, as clearly demonstrated in the College of Business decision process where fewer than half of the members were really involved with the decision. The involvement of these few member was less an aspect of their official duties as trustee members, and more a product of their status as senior faculty participating in the various ad hoc committees that reported to the President.

Layered Authority. The bureaucratic model found at Toshi University has some unique Japanese cultural characteristics as represented in the layering 
of authority that makes it difficult to determine the source of power. One example is the Ministry of Education and its layering of regulations over the various functions of decision-making at Toshi University. As the survey results show, even the faculty at Toshi University are unfamiliar with the relationship between their school and the Ministry of Education. Another aspect of this layering exists in almost every aspect of the internal governance process at Toshi University. The Western visitor to Japan soon observes that not all is what it appears. In fact, appearances in Japan are not expected to correspond to reality, and this circumstance is accepted, and even enjoyed and appreciated. For example, the Japanese place great emphasis on polite and respectful language, and as a result they are sometimes misunderstood by Westerners who do not understand the cultural subtleties behind the courtesies. Polite language is used for many purposes in Japan, including asking favors, initiating conversation with strangers, signaling between friends and acquaintances, and it can even be used to offend someone. The polite language itself might be viewed as a kind of wrapping, not unlike the wrapping of a gift, and one can never be quite sure what is beneath the wrapping. The Japanese tend to wrap everything, sometimes more than once, and great effort is always made in the presentation. Hendry (1993) relates the significance of the Japanese custom of wrapping:

A Western perception of the practice prepares us to regard wrapping as a means to obscure the object inside, whereas in a Japanese view it would seem that the function of wrapping is rather to refine the object, to add to it 
layers of meaning which it could not carry in its unwrapped form. (Hendry, p. 27)

This concept of wrapping can be extended to describe the layers of an organization that make it difficult to locate the center of power, if there is, in fact, a center. The researcher encountered these wrappings throughout the case study. In the decision to establish the College of Business, the wrapping was apparent in the multitude of committees that planned the process, some with long, elaborate and important titles that also had wide representation from every college and department at the University. In reality, these committees were probably much less influential on the decision-making process than a small group of faculty and administrators who worked closely with the President to carry out the decision. In fact, the role of the President in the process was not clearly described in any of the reports or other written communication. According to these reports, the decision evolved from the Future Planning Committee meetings and was shaped by the collegial participation of some of the faculty in the College of Arts and Education. On the other hand, the faculty reported on the survey that the President was the most influential in both the development and implementation of the decision. And this was certainly the case given the very strong patterns of personal authority at Toshi University.

\section{Summary and Conclusions}

The conclusion that was reached from the analysis of the research findings was that no one model can be used to describe the governance patterns that existed before and after the 1998 University Council reforms. Indeed, a 
mixture of models based on Japanese cultural values, such as consensus, harmony and group solidarity, is needed to describe the situation at Toshi University. It was also determined that the University Council reforms have served to either strengthen or weaken these various patterns of governance with respect to one or more functions of decision-making.

It is regrettable that there are so few case studies that examine the governance systems of Japanese universities. More of these studies are needed, especially ones that compare and contrast private with public universities. In addition, there is a need for longitudinal studies that will examine the long-term impact of the current reforms. Perhaps one of the more interesting issues raised in the study was the question of what is effective presidential leadership in Japan. More studies are needed that address this issue and provide profiles of presidents at various types of institutions who are using the major governance patterns to realize their vision.

The President at Toshi University is such a leader. The strong personal authority that the President represents appears to meet the needs of his institution. The President is effectively responding to the reforms and other environmental pressures that currently exist in Japan, such as the declining college cohort. During his tenure, he has tried to achieve a more unified, cohesive system of governance in which all of the faculty, staff and administrators work constructively for the good of the university. The Ministry of Education hopes that through its reform to give individual universities more autonomy over their decision-making that they will in turn become more 
functional. The governance system at Toshi University, unlike most national and public universities and many other private universities in Japan, is already functional. In fact, one of the most highly regarded Japanese higher education scholars in the world once referred to Toshi University as "one of the best examples of a well-managed university in Japan."

It would seem that as more universities in Japan adopt a more centralized decision-making system, it will be necessary to acquire a deeper understanding of the leadership styles that are effective in a Japanese cultural context. This case study provides such an opportunity because of the effectiveness of the strong personal authority that exists at Toshi University, such as that seen in the process to establish a College of Business. This new school is a credit to the leadership of the President because (1) he was able to use the major governance patterns to realize his vision; (2) he was able to utilize his authority and power to manage and plan effectively; and (3) he was able to sell the idea to the Ministry of Education, the faculty and external interest groups 


\section{References}

Altbach, P. G. (1983). Comparative university reform. In Comparative approaches to higher education: curriculum, teaching, and innovation in an age of financial difficulties: reports of the Hiroshima/OECD meetings of experts. Hiroshima, Japan : Hiroshima University, Research Institute for Higher Education.

Altbach, P. G. (1991). University Reform. In Altbach, P. G. (Ed.), International Higher Education: An Encyclopedia. (pp. 261-274). New York: Garland Pulbishing.

Arimoto, A. \& Weert, E. D. (1993). Higher education policy in Japan. In Goedegebuure, L. (Ed.), Higher education policy: an international comparative perspective. Oxford \& New York: Pergamon Press.

Arimoto, A. (1997). Market and higher education in Japan. Higher Education Policy, 10 (3/4), 199-210.

Baldridge, J.V. (1971a). Academic Governance. Berkeley, California: McCutchan.

Baldridge, J. V. (1971b). Power and conflict in the university. New York: John Wiley.

Baldridge, J. V., Curtis, D. V., Ecker, G. P. \& Riley, G. L. (1977a). Alternative models of governance in higher education. In Baldridge, J. V. \& Riley, G. L. (Eds.), Governing academic organizations. McCutchan Publishing Corp: Berkeley, CA.

Baldridge, J. V. \& Riley, G. L. (1977b). Governing academic organizations. McCutchan Publishing Corp: Berkeley, CA.

Barretta, M. J. (1987). Rikkyo university, Tokyo, Japan: a case study of governance at a private university. Doctoral Dissertation, University of Pittsburgh.

Beauchamp, E. R. \& Rubinger, R. (1989). Education in Japan: a source book. New York: Garland. 
Bess, J. L. (1988). Collegiality and bureaucracy in the modern university: the influence of information and power on decision-making structures. New York: Teachers College Press.

Christopher, R. C. (1983). The Japanese Mind. New York : Fawcett Columbine.

Clark, B. (1983) The higher education system: academic organization in cross-cultural perspective. Berkeley \& Los Angeles: University of California Press.

Cohen, M. D. \& March, J. G. (1974). Leadership and ambiguity. New York: McGraw-Hill.

College reform. (March 2, 2000). Mainichi Daily News.

Cummings, W. K. (1994). From knowledge seeking to knowledge creation: the Japanese university's challenge. Higher Education, 27, (4), 399-415.

Cummings, W. K. (1997). Private education in eastern Asia. In Cummings, W. K. \& Altbach, P. G. (Eds.), The challenge of eastern Asian education. State University of New York Press.

Dorfman, C. H. (Ed.). (1987). Japanese education today: a report from the U.S. study of education in Japan. U.S. Department of Education: Washington, D. C.

Education reforms may end exam hell. (November 7, 1998). The Japan Times. Eurich, N. P. (1981). Systems of higher education in twelve countries: a comparative view. Praeger: New York.

Findlay-Kaneko, B. (1998, November 6). Panel in Japan urges major university reforms. The Chronicle of Higher Education, p. A 69.

Green, M. F. (1997). Transforming higher education: views from leaders around the world. Phoenix, Arizona: Oryx Press.

Government plans system to evaluate national universities. (February 19, 2000). The Yomiuri Shimbun.

Hendry, J. (1993) Wrapping culture: politeness, presentation and power in Japan and other societies. Oxford: Clarendon Press.

Japan's Universities Need a Big Bang. (July 8, 1998 ). The Japan Times. 
Kitamura, K. (1991). Japan: an education-oriented society. In Altbach, P. G. (Ed.), International Higher Education: An Encyclopedia. (pp. 489-498). New York: Garland Publishing.

Lebra, T. S. (1991). Resurrecting ancestral charisma: aristocratic descendants in contemporary Japan. Journal of Japanese Studies, 17 (1), 59-78.

Lincicome, M. (1993). Focus on internationalization of Japanese education: nationalism, internationalization, and the dilemma of educational reform in Japan. Comparative Education Review, 37(2).

Manabe, S. (1996). Gendai daigakuron josetsu: Nihon mondai no ichikyokumen to shiteno daigaku mondai. [Higher education in Japan today: the university's problems as one aspect of the overall problems facing Japan]. Osaka, Japan: Kansai University of Economics.

Millett, J. D. (1978). New structures of campus power. Jossey-Bass: San Francisco.

Millet, J. D. (1985). Governance of higher education. In Husen, T. \& Postlethwaite, T. N. (Eds.), The international encyclopedia of education research and studies. (Vol. 4, p. 2061). Oxford: Pergamon Press.

Ministry agrees to make national universities independent. (September 20, 1999). . Nihon Keizai Shimbun.

Ministry of Education, Science, Sports and Culture, Japan (1996). Susamu daigaku kaikaku: daigaku no atarashii sugata. [New faces of Japan's universities: a brief introduction to advancing reforms]. Tokyo, Japan: The University of Tokyo, Center for Research \& Development. Ministry of Education, Science, Sports and Culture, Japan (1998a). Gakko kihon chosa houkokusho. [Report on the basic statistics related to schools]. Tokyo, Japan: Mombusho Daijin Kambo Chosa Tokeika.

Ministry of Education, Science, Sports and Culture, Japan (1998b). Monbu tokei yoran. [Handbook of educational statistics]. Tokyo, Japan: Ministry of Finance Press. 
Motohisa, K.. (1989). Financing higher education in Japan: trends and issues. Hiroshima, Japan : Hiroshima University, Research Institute for Higher Education.

Nagai, M. (1971). Higher education in Japan: its take off and crash. Tokyo: University of Tokyo Press.

Nakayama, S. (1989). Independence and choice: western impacts on Japanese higher education. In Altbach, P. G. \& Selvaratnam, V. (Eds.), From dependence to autonomy: the development of Asian universities. Boston: Kluwer Academic Publishers.

Narita, K. (1978). Systems of higher education: Japan. New York: International Council for Educational Development.

National Council on Educational Reform (1986). Summary of second report on educational reform. Tokyo: Office of the Prime Minister, Japan.

National universities should be privatized. (September 21, 1999). Nihon Keizai Shimbun.

Ninomiya, A. (1977). Private universities in Japan. Tokyo: The Private Universities Union.

Okano, K. \& Tsuchiya, M. (1999). Education in contemporary Japan: inequality and diversity. Cambridge University Press.

Osaki, H. (1997). The structure of university administration in Japan. Higher Education, 34, 151-163.

Owens, R. G. (1991). Organizational behavior in education. (4th ed.) Englewood Cliffs, N.J.: Prentice Hall.

Panel Advises Universities to Emulate U.S. (July 2, 1998). Mainichi Daily News. Panel urges reform for universities. (November 2, 1998). The Nikkei Weekly. Panel urges shift in emphasis from 'hensachi' system. (Nov. 1, 1999). Kyodo News Service.

Putting some meaning into independent universities. (September 20, 1999).

Asahi Shimbun.

Release of information by colleges sought. (January 1,1999). The Yomiuri Shimbun. 
Reischauer, E. O. (1988). The Japanese today. Cambridge, Massachusetts: The Belknap Press of Harvard University Press.

Shimbori, M. (1969). The sociology of a student movment - a Japanese case study. In Altbach, P. G. \& Lipset, S. M. (Eds.), Students in revolt. (pp. 283-309). Boston: Houghton Mifflin Company.

$60 \%$ of universities open to early graduation: survey. (October 25,1998$)$. Kyodo News Service.

Smith, H. L. \& Krueger, L. M. (1933). A brief summary of literature on leadership. Bloomington: Indiana University, School of Education Bulletin.

Snoddy, G. A. (1996). A comparative study of the strategies to maintain enrollments at Japanese and American private institutions of higher education as a response to decline in the population of traditional age students. Doctoral Dissertation: West Virginia University.

Taylor, F. W. (1911). The principles of scientific management. New York: Harper.

Tasker, P. (1988) The Japanese. New York: Truman Talley Books.

Teichler, U. (1997). Higher education in Japan: a view from outside. Higher Education, 34, 275-298.

Tokutake, Y. (1995). Education in Japan. ("About Japan" Series, Volume 8). Foreign Press Center: Tokyo, Japan.

Top universities talk of joing forces: discussions prompted by education ministry's plans to make national schools more accountable. (November 8, 1999). Nihon Keizai Shimbun.

Trow, S. (1987). Comparative reflections on leadership in higher education. In Altbach, P. G. \& Berdalh, R. (Eds.), Higher Education in American Society (Revised ed.). Buffalo, New York: Prometheus Books.

Trow, S. (1972). The expansion and transformation of higher education. International Review of Education, 18, 61-81. 
University Council (1998, October). 21 seiki no daigaku zoto kongo no kaikaku hoshin ni tsuite. Kyosoteki kankyo no naka de kosei ga kagayaku daigaku. [A vision for universities in the $21^{\text {st }}$ century and reform measures to be distinctive universities in a competitive environment]. Tokyo: Ministry of Education, Science, Sports and Culture, Japan. University entrance methods are key to quality learning. (October 27, 1998). Asahi Shimbun.

Universities need external appraisal. (October 27, 1998). The Yomiuri Shimbun.

Universities no longer a protected species. (February 10, 2000). Asahi Shimbun.

Universities RIP reform plans. (January 11, 2000). Asahi News Service.

Weber, M. (1947). The theory of social and economic orgnizations. New York: Free Press.

Yamamoto, S. (1993). Research and development versus traditionalism at Japanese universities. Higher Education Policy, $\underline{6}$ (2). 47-50.

Yamamoto, S. (2000, May). Making the grade: Japanese universities aim to 'outshine the competition'. Look Japan. 


\section{APPENDIX A}

\section{SCRIPT FOR INTERVIEW}




\section{Script for Interview}

Thank you for agreeing to participate in my study. The goal of my research is to help me to better understand the governance system and the governance patterns of Toshi University. The information gathered will be used for my doctoral dissertation. I want to point out several things to you before we start:

1. Your participation is entirely voluntary and you do not have to respond to every item or question;

2. Your responses will remain anonymous and confidentiality will be maintained.

Thank you for agreeing to participate in this study.

\section{Structured Interview Questions}

1. How would you describe your position as (name of position) in terms of major responsibilities?

2. As (name of position) how would you describe your interaction with the Trustees? the president? the deans? the department chairs? the faculty senate? the alumni? the community? What other authority groups do you interact with most frequently?

3. What have been some of the major decisions during the past couple of years at Toshi University? major decision affecting financial affairs? academic programs and instruction? faculty affairs? external relationships with the community? other?

4. For each of the above major decisions, which authority groups or individuals at Toshi University were most instrumental in its development and implementation?

5. How would you describe the way each of the above decisions was developed and implemented? Do you believe there has been wide spread support for each of these decisions?

6. From what I have read it appears that the Japanese Ministry of Education exerts considerable influence on private universities. Can you tell me more about this and about how Toshi University interacts with the Ministry?

7. How do you think the 1998 University Council reforms will affect governance at Toshi University? 


\section{APPENDIX B}

\section{COVER LETTER FOR SURVEY}

\section{(ENGLISH VERSION)}


Dear Faculty Member of Toshi University:

I am writing this letter to tell you a little about myself and to explain why I have sent you the attached questionnaire. I am a doctoral candidate at West Virginia University where my field of study is higher education administration. I am interested in learning more about the organizational structure of Toshi University and about the involvement of faculty in decision-making. The major aim of this questionnaire is to help me to better understand the extent to which Toshi University faculty are involved in the administration and governance of their institution.

Please be assured that your responses to this survey will remain anonymous and your confidentiality will be maintained. The sole purpose of this research is in connection with my doctoral dissertation. Upon completion of my case study, a copy of the dissertation will be presented to Toshi University for placement in its archives or for other purposes as may be deemed appropriate.

Your participation in this survey is entirely voluntary and you do not have to respond to every item or question. I would appreciate it if I could have the survey returned to the Toshi University Office of International Education by Wednesday, July 26, 2000. In closing let me thank you in advance for your cooperation with my study. I am very grateful for the opportunity to conduct research at this fine school.

\section{Clark Egnor}

West Virginia University Doctoral Candidate 
APPENDIX C

SURVEY INSTRUMENT

(ENGLISH VERSION) 


\section{FACULTY SURVEY}

\section{Section One}

Please check the appropriate area about your status at Toshi University:

1. In which college and department of Toshi University are you a full-time member of the faculty?

\begin{tabular}{|l|c|c|}
\hline $\begin{array}{l}\text { College of Arts \& Education } \\
\text { Department of Education } \\
\text { Department of Drama \& } \\
\text { Fine Arts } \\
\text { Department of English and } \\
\text { American Literature } \\
\text { Department of Foreign }\end{array}$ & $\begin{array}{c}\text { College of Agriculture } \\
\text { Department of Agronomy } \\
\text { Department of Agriculture }\end{array}$ & $\begin{array}{c}\text { College of Engineering } \\
\text { Department of Mechanical } \\
\text { Engineering } \\
\text { Department of Electronic }\end{array}$ \\
$\begin{array}{l}\text { Chemistry } \\
\text { Eanguages }\end{array}$ & & $\begin{array}{c}\text { Engineering } \\
\text { Department of Information- } \\
\text { Comunication Engineering } \\
\text { Department of Management }\end{array}$ \\
\hline
\end{tabular}

2. What is your position as a full-time member of the faculty?
A. __ Full professor (Kyooju)
C. ___ Lecturer (Kooshi)
B. Associate Professor (Jokyooju)
D. ___ Assistant (Joshu)

3. What is your age?
A. _ 20-29 years old
D. _ 50-59 years old
B. _ 30-39 years old
E. __ 60 years old or older
C. _ 40-49 years old

4. How many years of service have you had at Toshi University?
A. __ less than three years
C. ___ six to fifteen years
B. three to five years
D. ___ sixteen years of more

\section{Section Two}

Please check the appropriate area about your involvement in the governance of Toshi University.

5. Listed below are some of the administrative positions found at Toshi University. Please indicate whether or not you have ever served in the positions indicated and the number of years in each position.

\begin{tabular}{|l|l|l|l|}
\hline Position & Yes & No & $\begin{array}{c}\text { Years of } \\
\text { Service }\end{array}$ \\
\hline Board of Trustees Member (riji) & & & \\
\hline Dean of Faculty (gakubucho) & & & \\
\hline Department Chair (gakkacho) & & & \\
\hline Other: & & & \\
\hline
\end{tabular}


6. Please indicate your involvement on any university-wide committees at Toshi University.

\begin{tabular}{|l|c|c|c|}
\hline Committee & Yes & No & $\begin{array}{c}\text { Years of } \\
\text { Service }\end{array}$ \\
\hline Future Planning Committee (shoorai koosoo iinkai) & & & \\
\hline University Council (hyogiin-kai) & & & \\
\hline Other: & & & \\
\hline
\end{tabular}

7. Please rank the activities according to the amount of time you give to each one. Use \#1 for the activity in which you spend most of your time. Use \#4 for the activity in which you spend the least time.

A. ___ Teaching and preparation for teaching. Estimated hrs/wk?

B. Research, translating, editing, writing, and other scholarly work. Estimated hrs/wk?

C. ___ Social service. Estimated hrs/wk?

D. ___ Governance (i.e. committee meetings, administrative positions) Estimated hrs/wk?

\section{Section Three}

Please indicate your attitudes towards the governance processes at Toshi University.

8. Listed below are the major decision-making organs of Toshi University. Please indicate to what extent you are concerned about the decisions made at each level.

\begin{tabular}{|l|l|l|l|}
\hline Decision-making Body & $\begin{array}{c}\text { Deeply } \\
\text { Concerned }\end{array}$ & $\begin{array}{c}\text { Somewhat } \\
\text { Concerned }\end{array}$ & Indifferent \\
\hline Ministry of Education (Monbusho) & & & \\
\hline Board of Trustees (Rijikai) & & & \\
\hline President (gakucho) & & & \\
\hline Deans' Council (Buchokai) & & & \\
\hline Faculty Meetings of College (Kyoojukai) & & & \\
\hline Other: & & & \\
\hline
\end{tabular}

9. What do you think about the following opinions about the Ministry of Education and its control over higher education in Japan? Please circle 1 (Mostly Agree), 2 (Mostly Disagree), 3 (No opinion)

\begin{tabular}{|l|cc|}
\hline $\begin{array}{l}\text { The Ministry of Education has too much power over academic programs and instruction at } \\
\text { Toshi University }\end{array}$ & $\mathbf{2}$ & $\mathbf{3}$ \\
\hline $\begin{array}{l}\text { The Ministry of Education has too much power over financial affairs and other managerial } \\
\text { activities at Toshi University }\end{array}$ & $\mathbf{1}$ & $\mathbf{2}$ \\
\hline The Ministry of Education has too much power over faculty affairs at Toshi University & $\mathbf{1}$ & $\mathbf{2}$ \\
\hline $\begin{array}{l}\text { The Ministry of Education has too much power over Toshi University's relationship } \\
\text { with its external environment, such as community and alumni.. }\end{array}$ & $\mathbf{1}$ & $\mathbf{2}$ \\
\hline
\end{tabular}

10. Do you think the Ministry of Education exerts too much control over decision-making at Toshi University?

_ Yes __ No Please explain your views: 
11. Please comment on the establishment of the new College of Business at Toshi. In your opinion, which of the following groups were most instrumental in the development and implementation of this major decision.

\begin{tabular}{|l|l|l|l|}
\hline Group & $\begin{array}{c}\text { Instrumental in } \\
\text { Development }\end{array}$ & $\begin{array}{c}\text { Instrumental in } \\
\text { Implementation }\end{array}$ & No Opinion \\
\hline Ministry of Education (Monbusho) & & & \\
\hline Board of Trustees (Rijikai) & & & \\
\hline President and Executive Officers (Gakucho) & & & \\
\hline Deans' Council (Buchokai) & & & \\
\hline Faculty Meetings of College (Kyojukai) & & & \\
\hline Department Meetings (Gakkakaigi) & & & \\
\hline
\end{tabular}

12. Please indicate below whether or not you believe that there was adequate consultation about the establishment of the new College of Business for each of the following groups.

\begin{tabular}{|l|l|l|l|}
\hline Group & $\begin{array}{c}\text { Adequately } \\
\text { Consulted }\end{array}$ & $\begin{array}{c}\text { Not Sufficiently } \\
\text { Consulted }\end{array}$ & No Opinion \\
\hline University Faculty & & & \\
\hline University Students & & & \\
\hline University Alumni & & & \\
\hline Students' Parents & & & \\
\hline
\end{tabular}

13. Do you believe there was wide support for this decision to establish a new College of Business?
A. Yes
B. No
C. Don't know

14. Please rank the degree of impact of the decision to establish a new College of Business for each of the following areas. \#1 is strongest impact and \#5 is weakest impact.

\begin{tabular}{|c|c|c|c|c|c|}
\hline Area of Impact & 1 & 2 & 3 & 4 & 5 \\
\hline Academic programs and instruction & & & & & \\
\hline Financial affairs and other managerial activitie & & & & & \\
\hline University relations with business, parents and & & & & & \\
\hline Faculty affairs (e.g. hiring, tenure, promotion) & & & & & \\
\hline
\end{tabular}

15. Please check the top three changes during the past five years at Toshi University affecting your teaching, research and other duties as a full-time faculty member?

A. ___ faculty participation in the self-evaluation of the University.

B. ___ establishment of a new center for developing education methods

C. ___ training opportunities for the teaching staff

D. ___ requirement of the faculty to prepare and distribute syllabi for the classes they teach

E. ___ requirement of the faculty to have their students evaluate the classes they teach

F.___ increasing usage of Teaching Assistants

G. ___ other: Please explain: 
16. What do you think about the following changes pending in the reforms that could affect your teaching or research at Toshi University? Please circle 1 (Mostly Agree), 2 (Mostly Disagree), 3 (No Opinion)

\begin{tabular}{|c|c|c|c|}
\hline Collaborative research among faculty members of different departments should be encouraged & 1 & 2 & 3 \\
\hline Interdisciplinary courses taught by faculty of different departments should be encouraged. & 1 & 2 & 3 \\
\hline Faculty research should be more sensitive to community and business needs. & 1 & 2 & 3 \\
\hline Faculty should be required to participate in the self-evaluation of the University. & 1 & 2 & 3 \\
\hline Faculty should be required to prepare and distribute syllabi for the classes they teach. & 1 & 2 & 3 \\
\hline Students should evaluate their instructors and the classes they take. & 1 & 2 & 3 \\
\hline $\begin{array}{l}\text { Less emphasis should be placed on final examinations and more on written assignments and } \\
\text { attendance when grading students. }\end{array}$ & 1 & 2 & 3 \\
\hline The University should be more flexible about admitting students in the fall. & 1 & 2 & 3 \\
\hline The University should limit the number of credits undergraduates can earn each year. & $\mathbf{1}$ & 2 & 3 \\
\hline $\begin{array}{l}\text { The Monbusho should have less power and more power should be allotted to a university's } \\
\text { faculty and administration as a way to strengthen decision-making. }\end{array}$ & $\mathbf{1}$ & 2 & 3 \\
\hline
\end{tabular}

17. How would you rate the faculty's attitudes toward the changes in the curriculum that have occurred over the past five years?

\begin{tabular}{|l|l|l|l|}
\hline Group & Mostly Positive & Mostly Negative & No Opinion \\
\hline College of Arts \& Education Faculty & & & \\
\hline College of Engineering Faculty & & & \\
\hline College of Agriculture Faculty & & & \\
\hline
\end{tabular}

18. Do you mostly agree or mostly disagree with the following statements?

\begin{tabular}{|c|c|c|c|}
\hline & $\begin{array}{l}\text { Mostly } \\
\text { Agree }\end{array}$ & $\begin{array}{c}\text { Mostly } \\
\text { Disagree }\end{array}$ & $\begin{array}{l}\text { No } \\
\text { Opinion }\end{array}$ \\
\hline $\begin{array}{l}\text { Faculty's authority over the curriculum has been weakened by the } \\
\text { Ministry of Education reforms. }\end{array}$ & & & \\
\hline $\begin{array}{l}\text { Faculty's authority over matters of faculty affairs (e.g. hiring, tenure, } \\
\text { promotion) has been weakened by the Ministry of Education reforms. }\end{array}$ & & & \\
\hline
\end{tabular}

19. What do you think about the following proposals for reforming the existing university system in Japan as recommended recently by the University Council? Circle 1 (Mostly Agree), 2 (Mostly Disagree), 3 (No opinion)

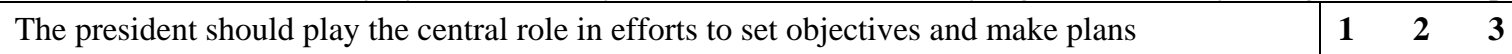
for education and research of university at large.

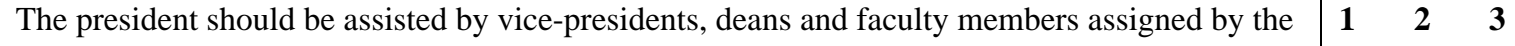
president to make necessary proposals and plans for the university administration.

The faculty senate should be responsible for making decisions about academic programs, instruction and research, but the presidents and deans should make the final decisions.

Presidents and deans should be responsible for making decisions about financial affairs and personnel and take responsibility for administration.

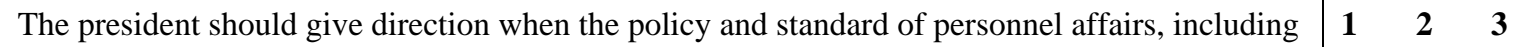
faculty appointments, are decided.

Present colleges and universities are so big and complex that it is necessary to train professional administrators and managers of higher education. 


\section{APPENDIX D}

\section{COVER LETTER FOR SURVEY}

(JAPANESE VERSION) 


\section{都市大学教職冝 $\sigma$ 皆样}

都市大学の教職目の皆样にアソケートにお答えいただきたく、こうして筆をとり ました。

私はアメリリカウェストバージニア州ウェストバージニア大学博士課程で高等教育 行政学を学んでいる、ェグナータラータと申します。私の博士課程研究の一環と

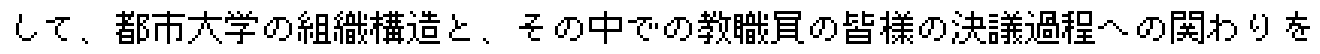
勉強しています。

このたび、教瞕目の皆样の行政、自治に関わる程度をよりよく理解したいと、そ の目安となるものとして、アンケートを取らせていただくことにしました。

このアンケートは無記名で、回答は他にもれることがないほか、私の博士号卒業 論文にのみ使われるということをどうぞご理解頂きたいと思います。私の卒業論 文は、コビー一部が、完成と同時に玉川大学に提出きれ、記録保管所に保存きれ るほか、適当と思われる方法で使われることとなっています。

アソケート回答は、自発的であること、全ての監問に答えなくても良いことをど うぞ心留放ておてくだきい。アンケートの回答を、2000年7月26日までに 国際教育事務所ま-で提出頂们た有り難く思います。

最後になりましたが、皆様のご協力と、そしてこのような立派な教育鼣関でのア ンケートができることに感謝申し上げたいと思います。

$$
\begin{gathered}
\text { ウェストバージニア大学博士課程 } \\
\text { ェダナータラータ }
\end{gathered}
$$




\section{APPENDIX E}

SURVEY INSTRUMENT

(JAPANESE VERSION 


\section{セクション1}

\section{馬胃アンケート}

都市大学での瞕種であなたに当てはまる瞕種にチェックしてくだきい。

1. 次の郝市大学のどの学部およけどの科でフルタイムの専任教貝をしていますか。

\begin{tabular}{|c|c|c|}
\hline $\begin{array}{l}\text { 立学吾 } \\
\text { 一教盲学科 } \\
\text { 一芸術学科 } \\
\text { 一英米文学科 } \\
\text { 一外国語学科 }\end{array}$ & 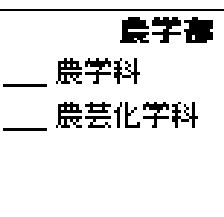 & 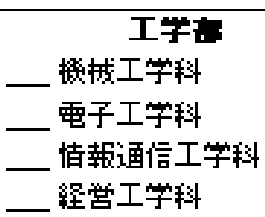 \\
\hline
\end{tabular}

2. 専任教冒としてのあなたのボジションは次のうちどれですか。
A. — Full professor (教粽)
B. - Associate Frofessor (助教兽)
C. _ Lecturer (諎師)
D. — Assistant (助手)

3.あなたの年路は?
A. $20-29$ 才
B. - $30-39$ 才
C. - $40-49$ 才

D. - 50-59 才

E. 一 60 才以上

4. 都市大学で何年はたらいていますか？
A. 3 年以内
B. 一 3 年的 5 年以内
c. 6 年加的 15 年以内
D.— 16 年以上

セクション 2

都市大学の統括管理で、あなたがあてはまるものにチェックして下さい。

5.下記のリストは、都市大学にあるポジションです。下記の看圱に就いたことがあるかどうか、

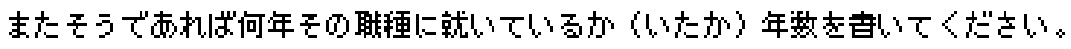

\begin{tabular}{|c|c|c|c|}
\hline ボジション & ある & あい & 年敢 \\
\hline \multicolumn{4}{|c|}{ Board of Trustees Member (理事) } \\
\hline \multicolumn{4}{|l|}{ De an of Fac uly ('学部長) } \\
\hline \multicolumn{4}{|l|}{ De partment Chair (主任) } \\
\hline 宅の他: & & & \\
\hline
\end{tabular}




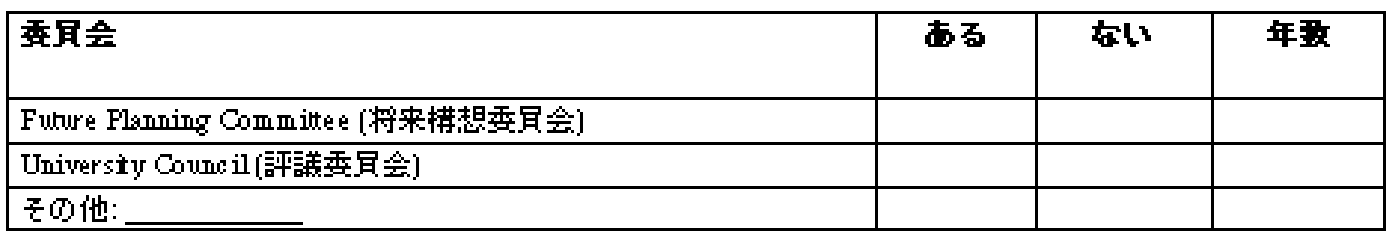

7. 次のうちであなたが一番時間を费やすものから順に 1 からら 4 とランクをつけてくだきい。 1 は一番所要時間が高いもので、4 は所要時間が低いものです。

A.—教える時間とそれに要する準㑤時間。大体の所要時間は?

B.—研究、翻訳、編集、著吉、气の他学問的な仕事。大体の所要時間は?

C. 一社会的なコミュニティーサービス。大体の所要時間は?

D. 一統括管理〈たとえば、香只会ミーティンダや管理部門の仕事〉。大体の所要時間は？

\section{セクション}

都市大学の管理処理に対してのあなたの意見を教えてくだきい。

8. 下記のリストは都市大学での每決断決定がなされている部所です。これらの每郡所で決定される決 断にあなたがどれ位関心索持っているか教えてくだきい。

\begin{tabular}{|c|c|c|c|}
\hline 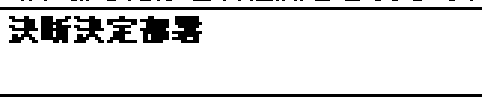 & $\begin{array}{l}\text { 大本图心を } \\
\text { 持っている }\end{array}$ & $\begin{array}{c}\text { まあまあ目心た } \\
\text { 持っている }\end{array}$ & $\begin{array}{r}\text { 全然用心を } \\
\text { 持っていない }\end{array}$ \\
\hline \multicolumn{4}{|l|}{ Ministry of Ed ucation (文部省) } \\
\hline \multicolumn{4}{|l|}{ Board of Trustees (理事侌) } \\
\hline \multicolumn{4}{|l|}{ President ('学長) } \\
\hline \multicolumn{4}{|l|}{ De ans' Council( 部長念) } \\
\hline \multicolumn{4}{|l|}{ Faculty Me etings of College (教擅侌) } \\
\hline その他: & & & \\
\hline
\end{tabular}

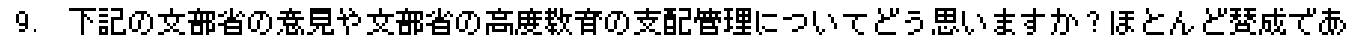

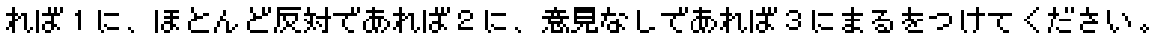

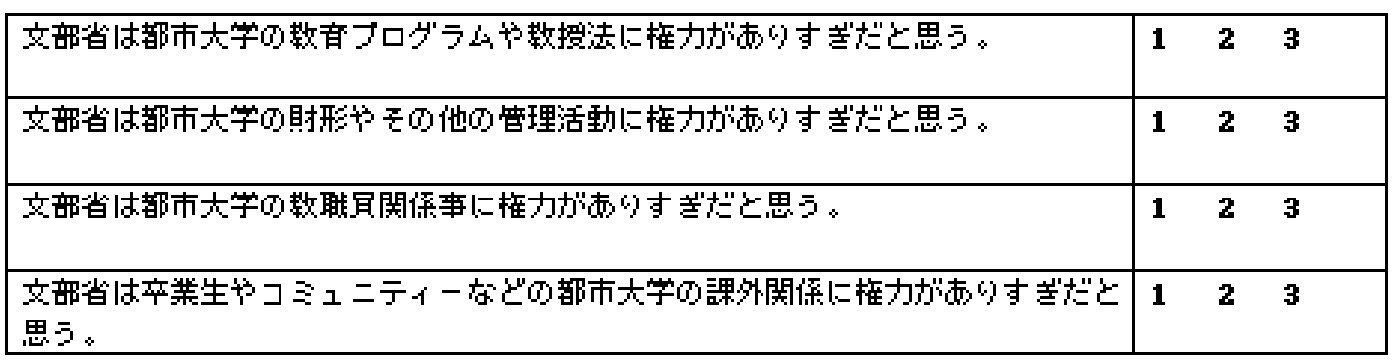

10.あなたは、都市大学が每決断をするのに、文部省が竦理干涉しすぎだと思いますか？ はい —いいえい゙うしてですか？説明してください。： 
11. 都市大学経営学郡設立にあたって、あなたの意見をおききしますが、次のどのグルーブ゙

一番措想進展に役立ったか、そしてどのダルーブが主な決断を施行しましたか？

\begin{tabular}{|c|c|c|c|}
\hline クルーフ & 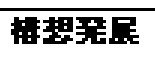 & 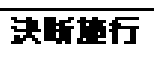 & 意見なし \\
\hline \multicolumn{4}{|l|}{ Ministry of Ed wation (文䑙省) } \\
\hline \multicolumn{4}{|l|}{ Board of Trustees (理事会) } \\
\hline \multicolumn{4}{|l|}{ President and Exec uhive Ofticers ( } \\
\hline \multicolumn{4}{|l|}{ De ans' Council( 部長念) } \\
\hline \multicolumn{4}{|l|}{ Faculty Me etings of College (教授侌) } \\
\hline De partment Meetings [学科会㦈] & & & \\
\hline
\end{tabular}

12. 経営学部設立にあたり、次の每グルーブに十分な協譜があったと思いますか？

\begin{tabular}{|l|l|l|l|}
\hline ケルーフ & 十分あった & 十分でなかった & 奎見はし \\
\hline 大学の教联員 & & & \\
\hline 大学生 & & & \\
\hline 大学の卒業生 & & & \\
\hline 学生の保瀑者 & & & \\
\hline
\end{tabular}

13. 経営学部設立の決断に対し、幅広いサボート〈支操〉があったと思いますか。

\begin{tabular}{|l|l|l|}
\hline A. はい & B.ゆい & C.わからない \\
\hline
\end{tabular}

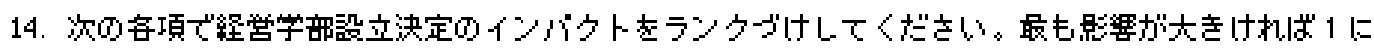
少なければ 5 に印をつけてください。

\begin{tabular}{|c|c|c|c|c|c|}
\hline Area of Inpael & $\mathbf{1}$ & 2 & $\mathbf{3}$ & 4 & 5 \\
\hline アカデミックブロダラムと講義 & & & & & \\
\hline 財形諸事とその他の管理活動 & & & & & \\
\hline ビジネス、父兄、卒業生と大学の関保 & & & & & \\
\hline 教渄只関保（㕍用、保有権、出世など) & & & & & \\
\hline
\end{tabular}

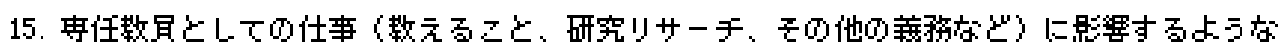
変化が、過去 5 年間に都市大学で”ありましたか。密化の大きいもの3つにチェックしてください。

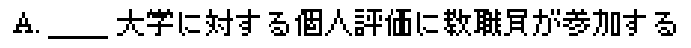
B.—教音メソッドを展開する新しいセンターの設立
C.—教貝のためのトレーニングの榙会

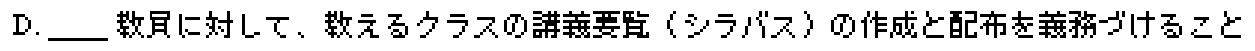
E.——教貝が学生にクラスの評価をしてもらうことの義净づけ。
F.—助手の利用をふやすると。
G.——の他：説明してください 


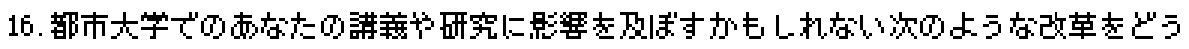

思いますか？大体琶成なら 1、大体反対なら 2、意見なしなら3に丸をつけてください。

\begin{tabular}{|c|c|c|c|}
\hline 每学料の教娥員との間の共同研究が推㤨されるべきだ。 & & & \\
\hline 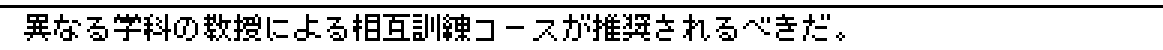 & 1 & 2 & 3 \\
\hline コミュニティーとビジネスの必要性に教㙂研究はもっと敏感でなければならない。 & $\mathbf{1}$ & 2 & 3 \\
\hline 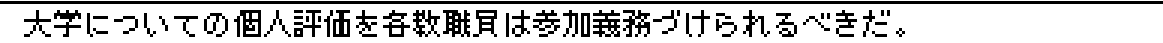 & $\mathbf{1}$ & 2 & 3 \\
\hline 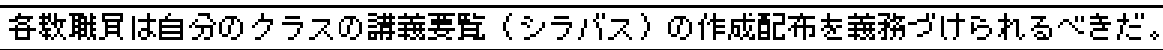 & 1 & 2 & 3 \\
\hline 学生は、自分のクラスの教噯と㜔業内客を評価するべきだ。 & $\mathbf{1}$ & 2 & 3 \\
\hline $\begin{array}{l}\text { 学生成結評価は、期末テストにあまり重視せず、もっと論文の宿題や出席を重視する } \\
\text { ゙きだ。 }\end{array}$ & $\mathbf{1}$ & $\mathbf{2}$ & 3 \\
\hline 大学は、秋季に学生を受け入れる体制にもっと柔軟であるべきだ。 & 1 & $\mathbf{2}$ & 3 \\
\hline 学生が取得できる年間単位教を大学側は限定するべきだ。 & $\mathbf{1}$ & $\mathbf{2}$ & $\mathbf{3}$ \\
\hline 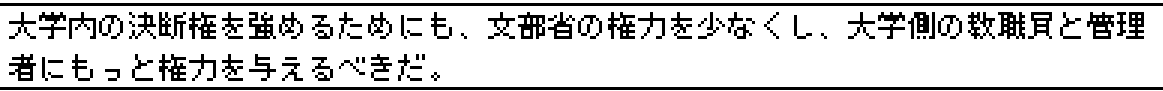 & & 2 & $\mathbf{3}$ \\
\hline
\end{tabular}

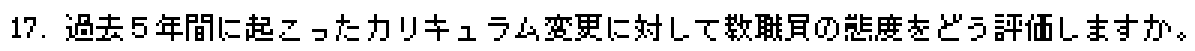

\begin{tabular}{|c|c|c|c|}
\hline クルーフ & 大体肯宝的 & 大体䂞宝的 & 意見なし \\
\hline 文学部の教聠咠 & & & \\
\hline 工学部の教倳肙 & & & \\
\hline 農学部の教联肙 & & & \\
\hline
\end{tabular}

18. 次の事項に大体楂成ですか。皇れとも大体反対ですか。

\begin{tabular}{|c|c|c|c|}
\hline & 大体瑟席 & 大体反对 & 意見なし \\
\hline カリキュラムに関する教聠只の権限が文部少によって弱らられている & & & \\
\hline 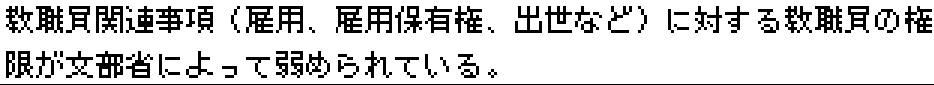 & & & \\
\hline
\end{tabular}


に、大体反対なら 2 に、意見なしなら 3 に丸をつけてください。

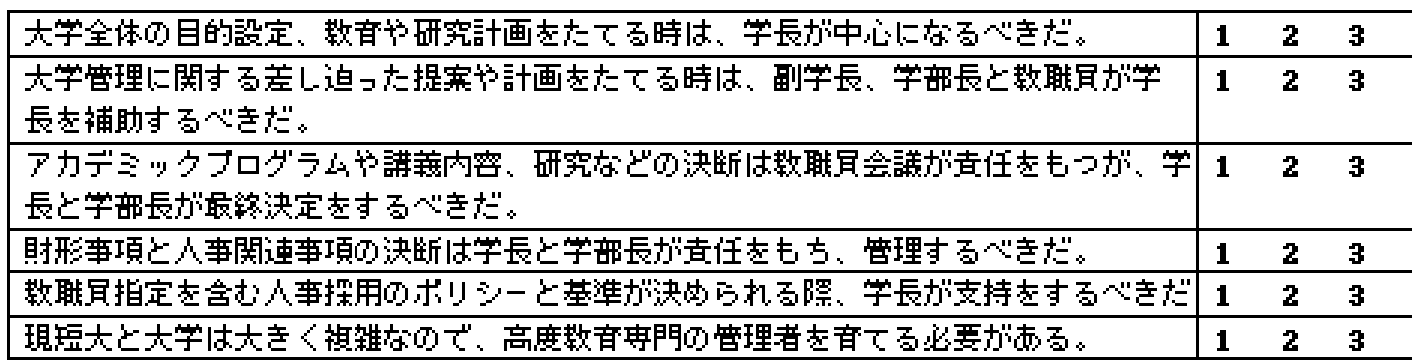

ご協力、大変ありがとうございました。 